Check for updates

Cite this: RSC Adv., 2019, 9, 38309

\title{
New dimensions in calix[4]pyrrole: the land of opportunity in supramolecular chemistry
}

\author{
Ishfaq Ahmad Rather, ${ }^{a}$ Shafieq Ahmad Wagay, ${ }^{a}$ Md Saquib Hasnain (D)*b \\ and Rashid $\mathrm{Ali}^{* a}$
}

The quest for receptors endowed with the selective complexation and detection of negatively charged species continues to receive substantial consideration within the scientific community worldwide. This study is encouraged by the utilization of anions in nature in a plethora of biological systems such as chloride channels and proteins and as polyanions for genetic information. The molecular recognition of anionic species is greatly interesting in terms of their favourable interactions. In this comprehensive review, in addition to giving accounts of some selected syntheses, we illustrated diverse applications ranging from molecular containers to ion transporters and drug carriers of a supramolecular receptor named calix[4]pyrrole. We believe that the present review may act as a catalyst in enhancing the novel applications of calix[4]pyrrole and its congeners in the other dimensions of science and technology.

Received 14th September 2019 Accepted 6th November 2019

DOI: 10.1039/c9ra07399j

rsc.li/rsc-advances

molecules such as calixpyridines and calixpyridinopyrroles. ${ }^{15}$ In addition to acting as novel solid supports to separate anion mixtures and also as anion transporters across lipid bilayer membranes, ${ }^{16}$ they have found significant applications in fluorescent, ${ }^{17}$ colorimetric ${ }^{18}$ and electrochemical signaling devices..$^{19}$ In addition to this, the anion binding ability of C4Ps makes them efficient in various domains of daily life; for example, they have found applications in waste-water treatment, ${ }^{20}$ composites in food packaging, storage, preservation, detection of pollutants, removal of heavy metal ions, etc. ${ }^{21-23}$

In the past two decades, many transformations and modifications ${ }^{5,24-27}$ have been carried out to tune the binding affinity of C4Ps including $\beta /$ meso-substitution(s), strapping and appending of aromatic rings at the meso-positions. ${ }^{28-32}$ Among these, the simplest method is the incorporation of a single arm into the C4P core (2, Fig. 1). On one hand, as can be seen in Fig. 1, structures 3 and 4 are two and four-walled C4P derivatives, respectively, and $\mathbf{5}$ is a strapped system. On the other hand, the more intricate and factually difficult-to-synthesize $\mathbf{6}$ is the capped system; its synthesis still remains a challenge. To the best of our knowledge, among various modified C4P skeletons reported in the literature, strapped C4Ps are found to be the most operative in anion binding territories. The strapping of C4Ps is the mode to amend their structural behaviour, which in turn accounts for their binding performance. The selection of the strap plays a vital role in enhancing the inherent anion binding affinity of C4Ps as well as in governing the receptor anion stoichiometry. Because the degree of preorganization increases from 2 to $\mathbf{6}$, it might be expected that the thermodynamics of

${ }^{a}$ Department of Chemistry, Jamia Millia Islamia, New Delhi-110025, India. E-mail: rali1@jmi.ac.in

${ }^{b}$ Department of Pharmacy, Shri Venkateshwara University, NH-24, Rajabpur, Gajraula, Amroha, U.P., India. E-mail: msaquibhasnain@gmail.com 

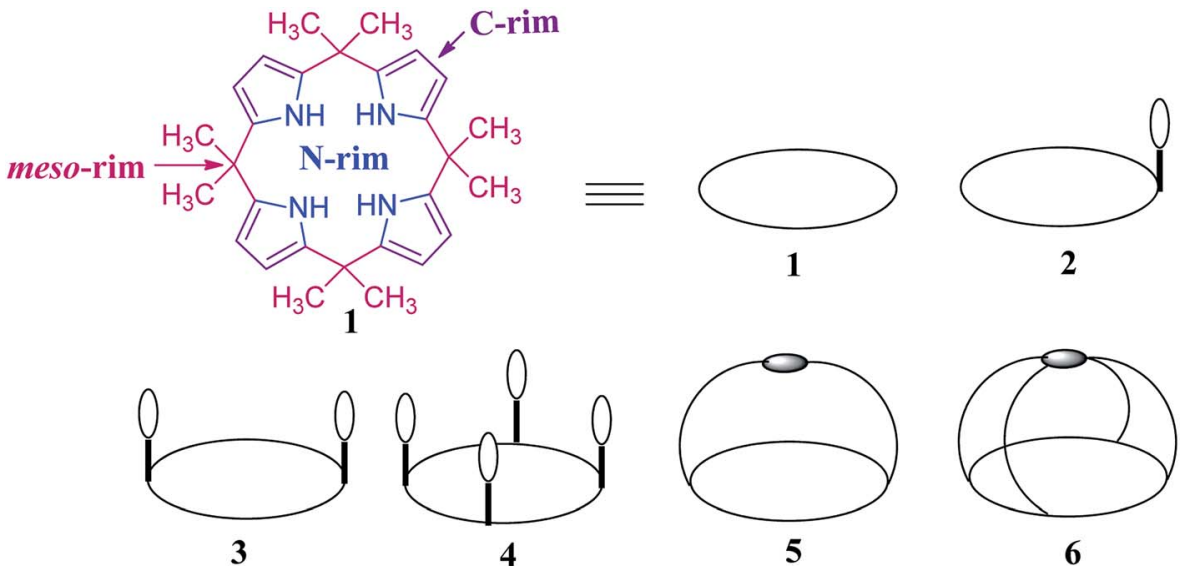

CHALLENGE

Fig. 1 Different modifications of the basic core of C4P systems.

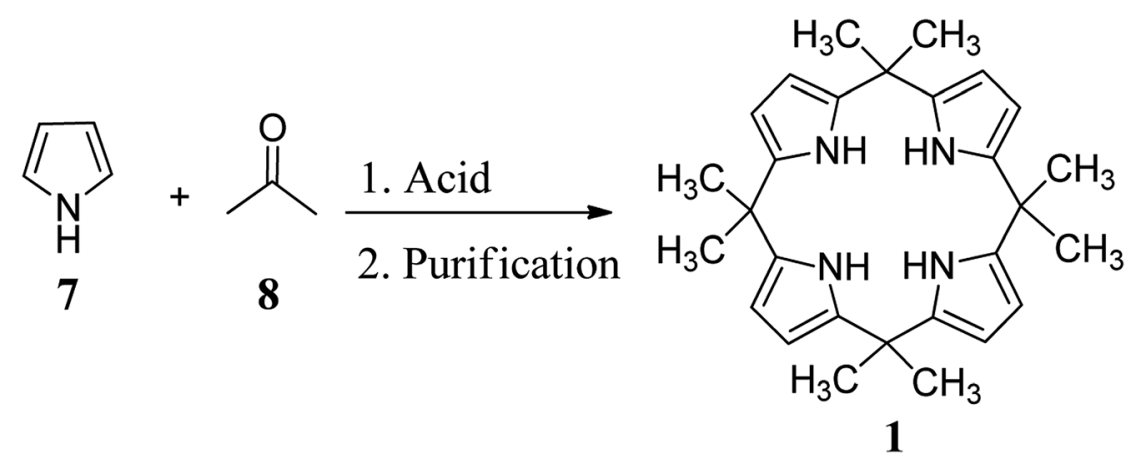

Scheme 1 Synthesis of octamethylcalix[4]pyrrole (OMCP).

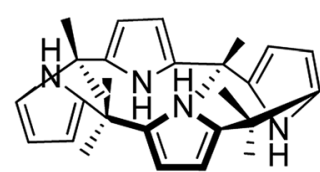

1,2-Alternate

9

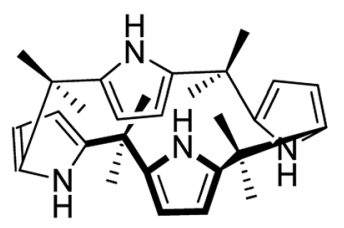

1,3-Alternate

10

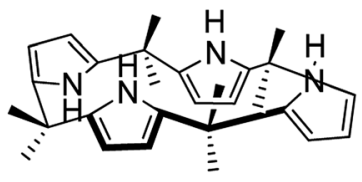

Partial cone

11

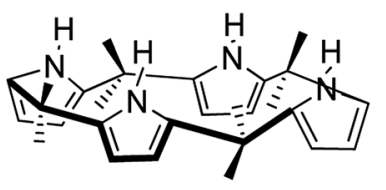

Cone

12

Fig. 2 Different conformations of C4P.

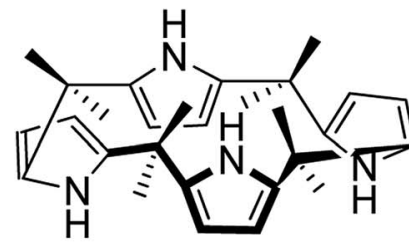

1, 3-Alternate

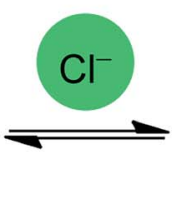

10

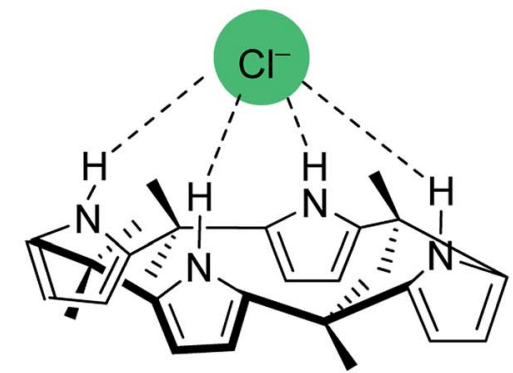

Cone conformation

Fig. 3 Transformation of the 1,3-alternate conformation into the cone conformation via anionic species. 


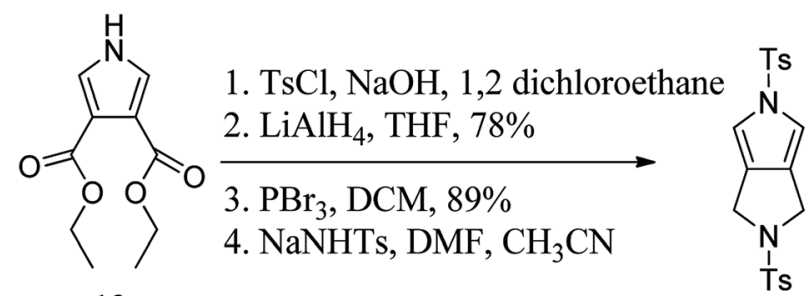

13
14
1. $\mathrm{NaOMe}, \mathrm{THF}$

$\underset{\text { 2. TFA, Acetone }}{\stackrel{\mathrm{MeOH}, 91 \%}{\longrightarrow}}$ $20 \%$

Scheme 2 Synthesis of $\beta$-substituted C4P.<smiles>CC1(C)c2[nH]c(c(F)c2F)C(C)(C)c2[nH]c(c(F)c2F)C(C)(C)c2[nH]c(c(F)c2F)C(C)(C)c2[nH]c1c(F)c2F</smiles>

16<smiles></smiles>

19<smiles></smiles>

17<smiles></smiles><smiles></smiles>

18

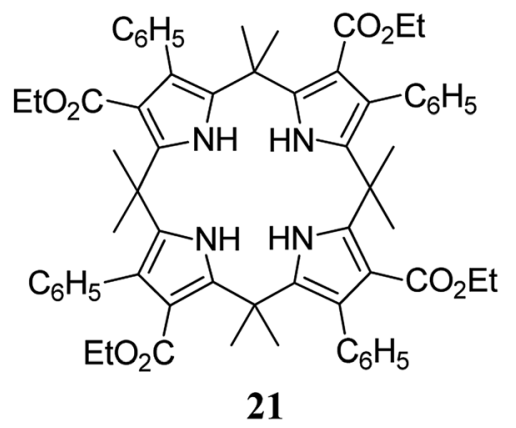<smiles></smiles><smiles></smiles>

23

Fig. 4 Structures of various $\beta$-substituted C4Ps. 


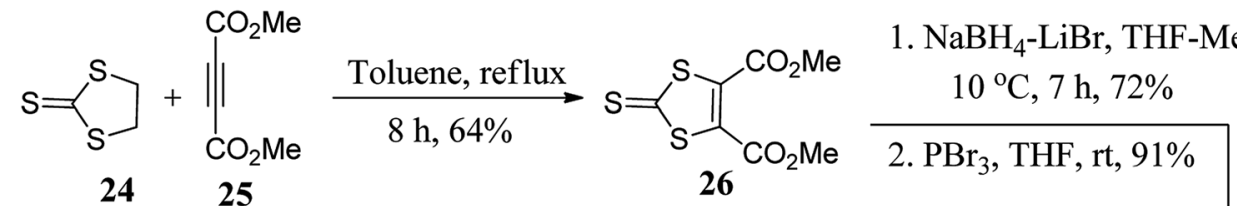

3. TsNHNa, DMF $80{ }^{\circ} \mathrm{C}, 2 \mathrm{~h}, 61 \%$<smiles>CC(C)=C1Sc2ccccc2S1</smiles><smiles>CCCSC(C)=C1Sc2ccccc2S1</smiles>

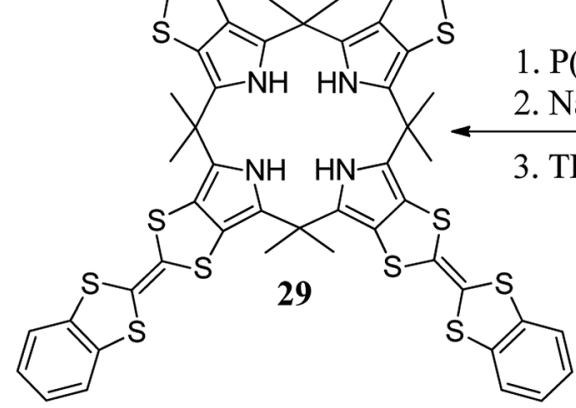

Scheme 3 Synthesis of benzo TTF-C4P.<smiles>CCCSC1=C(SCCC)SC(=C2Sc3c[nH]cc3S2)S1</smiles><smiles>c1[nH]cc2c1SC(=C1Sc3cscc3S1)S2</smiles><smiles>CCCCC(C)C(C)=O</smiles>

Scheme 4 Synthesis of S-Pr-TTF-C4P and thieno-TTF-C4P.

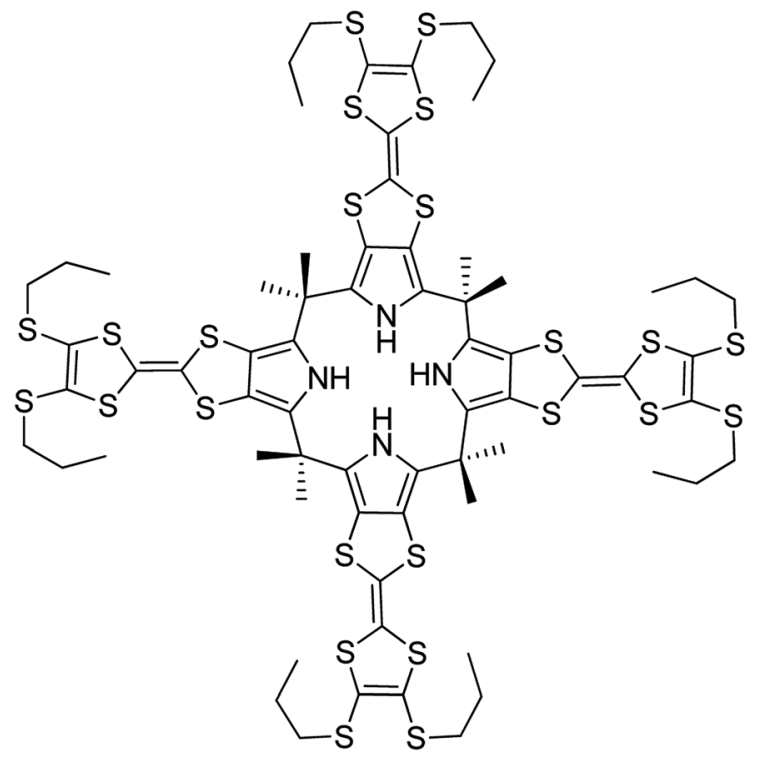

31, S-Pr-TTF-C4P
4. $\mathrm{Hg}(\mathrm{OAc})_{2}$ $\mathrm{CHCl}_{3}-\mathrm{AcOH}$ rt, 4 h, $99 \%$

5. DDQ, Toluene<smiles>O=c1sc2cn([As][As])cc2s1</smiles>
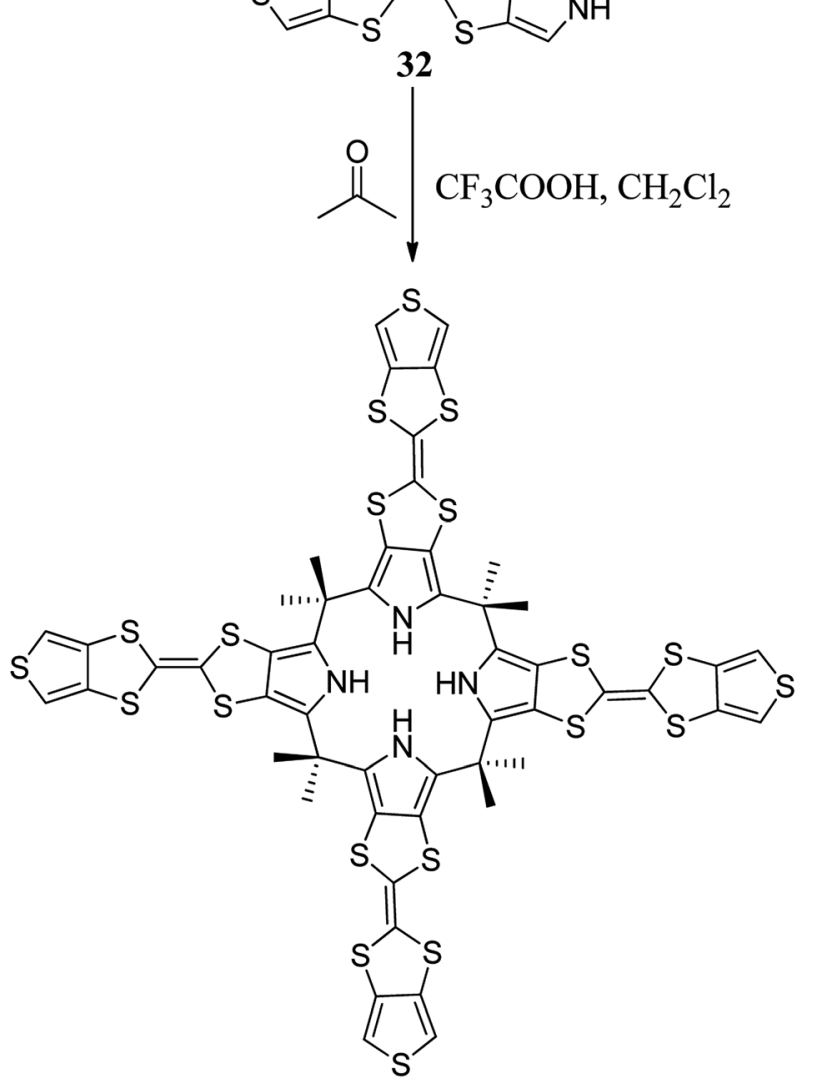

33, Thieno-TTF-C4P

33, Thieno-TTF-C4P 


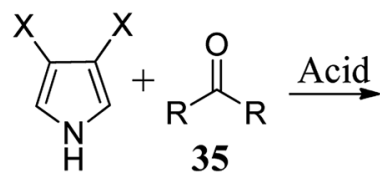

$\mathrm{X}=\mathrm{H}, \mathrm{F}$

34<smiles>[X]c1c[nH]c(C([R])([R])c2[nH]cc([X])c2[X])c1[X]</smiles>

38

Scheme 5 Synthesis of meso-substituted C4Ps.

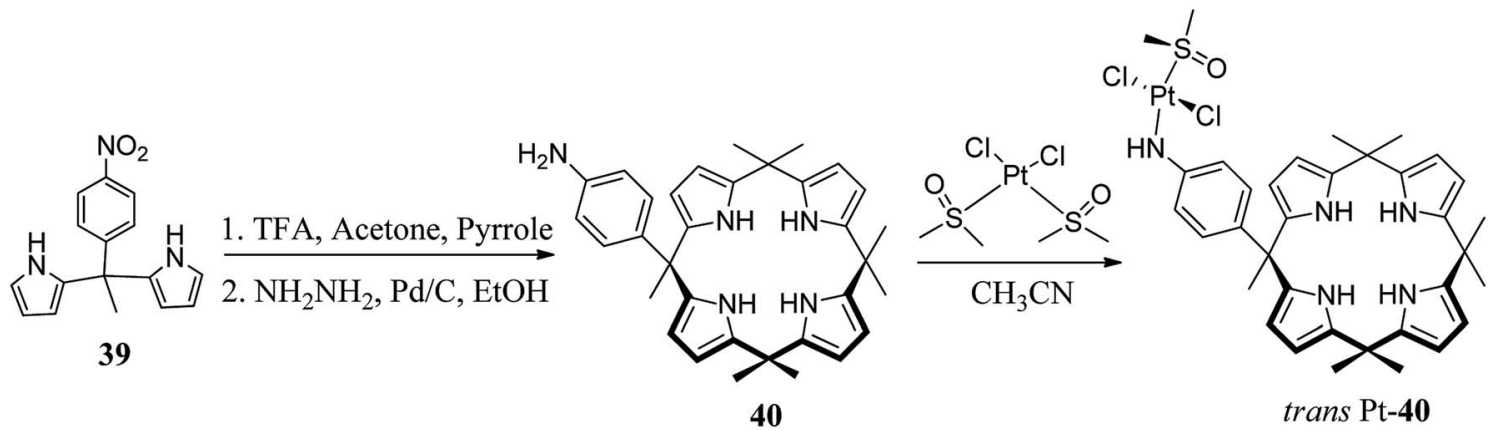

Scheme 6 Synthesis of C4P-derived meso-p-nitroaniline trans-coordinated to a Pt(॥) center.

binding as well as the inherent anion selectivity for properly tailored anionic substrates would subsequently increase. It has also been observed from the literature that the strapped system 5 has inherent advantages over the deep cavity system $4 .^{33-39}$ We are fairly certain that once the synthesis of $\mathbf{6}$ is achieved, it will definitely provide a new dimension to the C4P chemistry.

The first synthetic approach for C4P was carried out by Baeyer in 1886 in terms of hydrochloric acid-catalyzed condensation of pyrrole with acetone (Scheme 1). ${ }^{27}$ Three decades later, the same reaction was repeated by Chelintzev et al., and they proposed the cyclic tetrameric porphyrinogen structure. ${ }^{40}$ The same synthesis was improved by Rothemund and Gage in 1955 by employing methane sulfonic acid as a catalyst. ${ }^{41}$ In addition to these significant findings, C4Ps were studied occasionally in the next 100 years after their discovery., ${ }^{52-44}$ In 1990, Floriani and teammates commenced a widespread work on deprotonated calixpyrroles. The reconstruction and anion binding properties of C4P 1 were first determined in 1996 by J. L. Sessler and teammates at the University of Texas (Austin); they demonstrated that these macrocycles have many novel applications in diverse areas. ${ }^{5}$ Since then, this area of research has been continuously growing in all directions and has resolved several problems for chemists. However, we believe that this wonderful area of research is still immature, and there is a continuous need to design and synthesize more interesting and easily fabricated C4P-based receptors with inherent binding abilities. Keeping the extensive literature on C4Ps in view, we have organized the overall

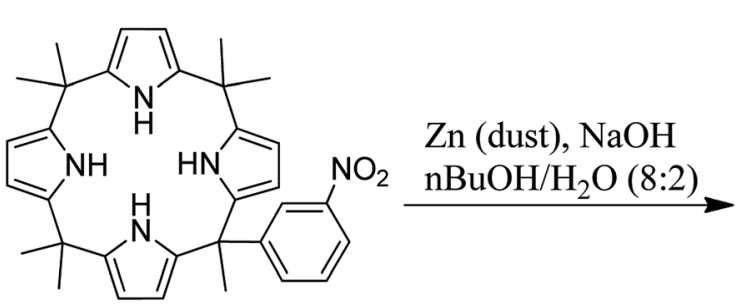

41

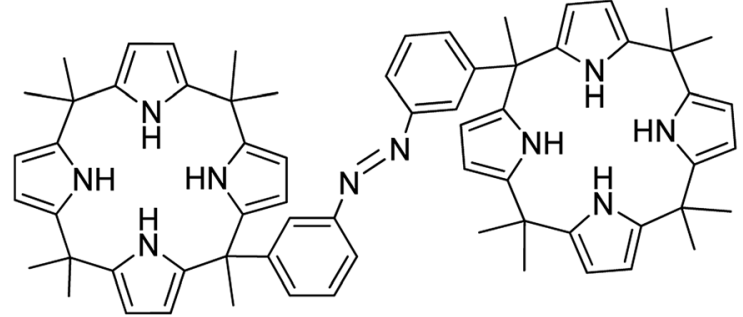

42

Scheme 7 Synthesis of 3,3'-bis(meso-heptamethylC4P)azobenzene 42. 
<smiles>Nc1cccc(N)n1</smiles>

43<smiles>CC(CCC(=O)O)(c1ccc[nH]1)c1ccc[nH]1</smiles><smiles>CCCC(C)(c1ccc[nH]1)c1ccc[nH]1</smiles><smiles>CC(N)=O</smiles>

$\mathrm{HN}$<smiles></smiles>

$\underset{\mathrm{rt}, \text { overnight, } 2 \%}{\stackrel{\mathrm{BF}_{3} \cdot \mathrm{OEt}_{2}, \text { Acetone }}{\longrightarrow}}$<smiles>N</smiles><smiles>CC(=O)CCC(C)(c1ccc[nH]1)c1ccc[nH]1</smiles>

45

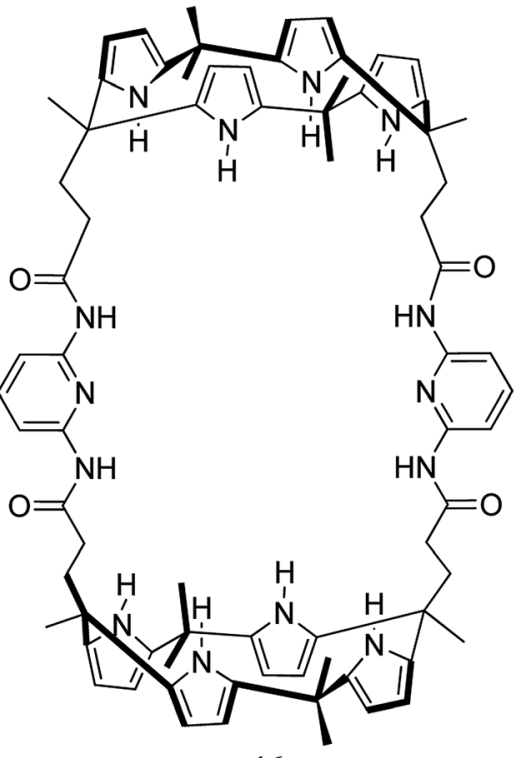

46

Scheme 8 Synthesis of the bis-C4P capsule starting from 2,5-diaminopyridine and dipyrromethane.

content into two major parts. The first part is devoted to some selected syntheses, and the second part is reserved for the applications of various functionalized C4Ps.

\section{Structures and stabilities of various conformations of calix[4]pyrrole}

The fundamental structure of $\mathrm{C} 4 \mathrm{P}$ consists of four pyrrole rings and is divided into three major parts, viz. C-rim, N-rim, and meso-rim (Fig. 1). ${ }^{45}$ After extensive study, Jonathan L. Sessler and teammates concluded that unsubstituted C4Ps exist in four different conformations, analogous to calix[4]arene (Fig. 2). They also observed that the thermodynamically more stable 1,3alternate conformation is highly favoured in the absence of anionic guests, as determined by theoretical as well as by X-ray studies. Molecular mechanics calculations also indicate that the 1,3 -alternate conformation is the most stable conformation, with a torsional interaction energy about 1 to $2 \mathrm{kcal} \mathrm{mol}^{-1}$ lower than that of the other conformations. In the absence of an

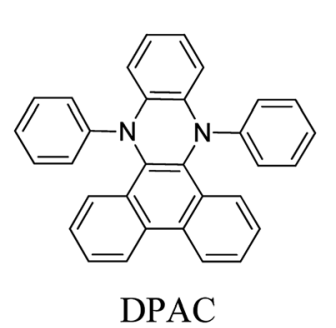

47

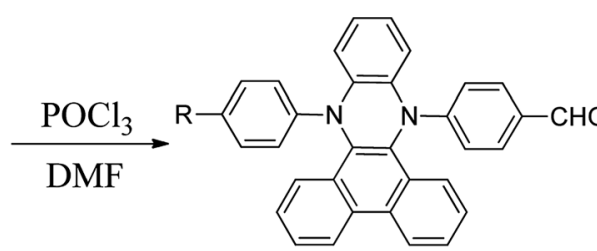

$\mathrm{R}=\mathrm{H}, \mathrm{CHO}$

48<smiles>[R]c1ccc(N2c3ccccc3N(c3ccc(CO)cc3)c3c2c2ccccc2c2ccccc32)cc1</smiles>

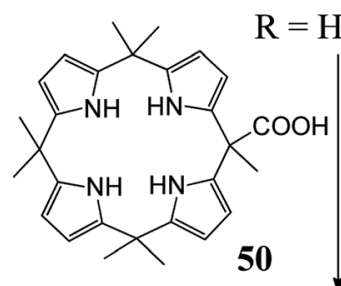

\section{EDCl, DMAP} $\mathrm{DCM}$

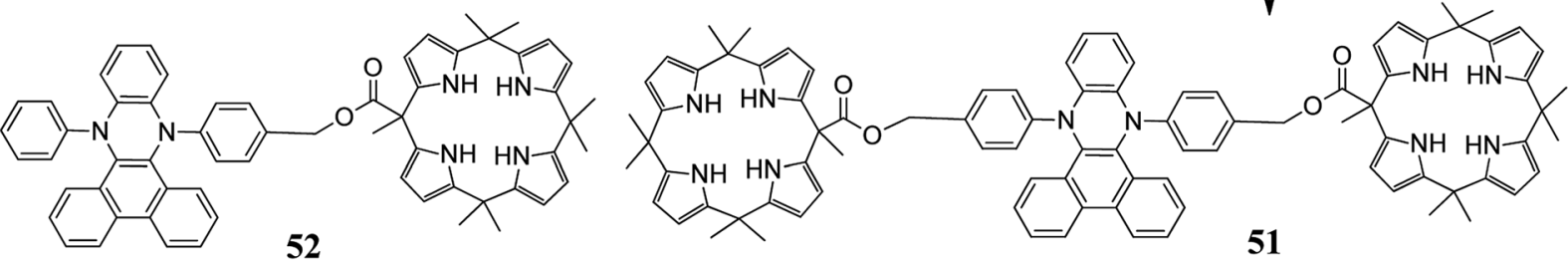

Scheme 9 Synthesis of DPAC-bisC4P 51 and DPAC-monoC4P 52. 


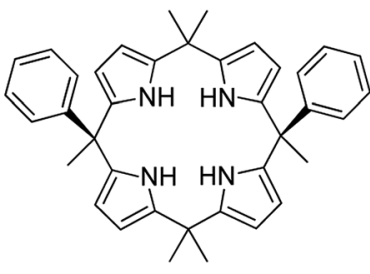

53

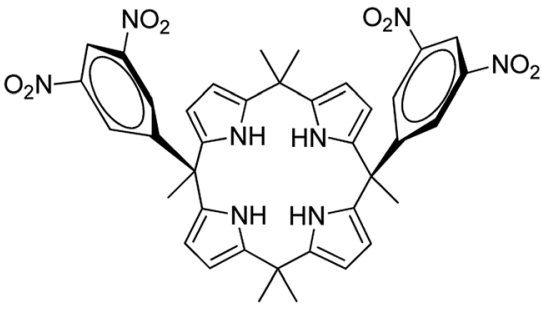

56

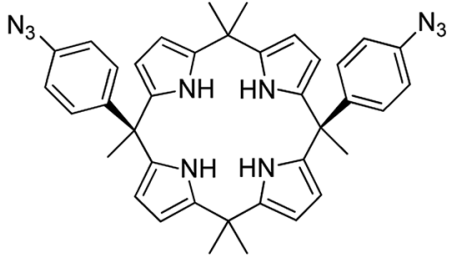

54

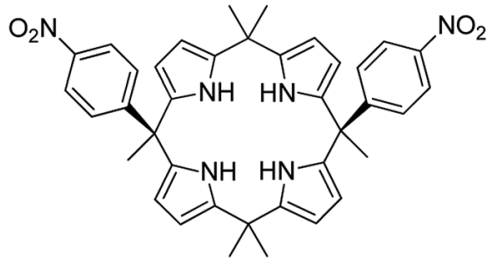

55



57

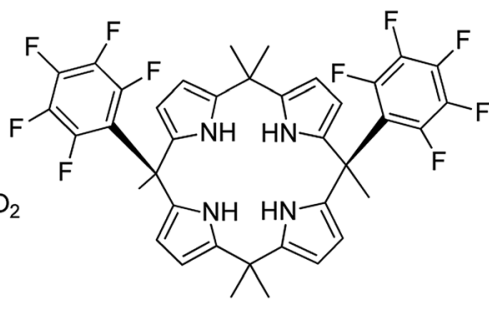

58

Fig. 5 Molecular structures of two-walled aryl-extended C4Ps.

anion, the predicted stability sequence of various conformers of C4Ps is 1,3-alternate > partial cone $>1,2$-alternate $>$ cone; this has been confirmed by gas phase as well as solution phase $\left(\mathrm{CH}_{2} \mathrm{Cl}_{2}\right)$ studies along with the computational support of energy optimization by BLYP/6-31G and BLYP/6-31+G**. It has also been revealed in the literature that the 1,3-alternate conformation is most benefitted by electrostatic effects aided by anti-orientation of each adjacent pyrrole pair. On the other hand, the cone conformation mostly experiences electrostatic repulsion by virtue of the syn-orientation of all the pyrrole rings and has been found to be the dominant conformation in the presence of anionic guest species by virtue of hydrogen bonding interactions among the four pyrrolic $\mathrm{NH}$-groups and anionic species (Fig. 3). ${ }^{46}$

\section{Synthesis of calix[4]pyrroles}

Three universal methods are commonly used for the synthesis of C4Ps. These include:

(i) $[1+1+1+1]$ condensation: direct synthesis or one-pot approach of ketones with pyrrole and its derivatives in the presence of an acid catalyst.

(ii) $[2+2]$ condensation: acid-catalyzed condensation of dipyrromethanes with ketones.

(iii) $[3+1]$ condensation: acid-catalyzed reaction of tripyrrane with pyrrole.

It is very clear from the literature that the one-pot approach is the most accepted of the aforementioned methods for the generation of a variety of C4Ps using either a Lewis acid or Brønsted acid in a catalytic amount. On the other hand, in recent years, acidic zeolites and graphite oxide have also been used as powerful catalysts for the synthesis of diverse dipyrromethanes as well as C4Ps in acceptable yields. ${ }^{47}$

\section{1. $\quad \beta$-Substituted calix[4]pyrroles}

To tune the binding ability of C4Ps (hosts) with their guests (anions), researchers worldwide have designed and synthesized various $\beta$-substituted calix[4]pyrrole derivatives. For example, in 2011, Sessler's group synthesized $\beta$-octaalkyl-substituted C4P derivative 15 using $N$-tosylpyrrolidine pyrrole and acetone in satisfactory yield (Scheme 2$).^{48}$ On the other hand, with the aid of well-adopted synthetic procedures, scientists have also carried out the synthesis of various other $\beta$-substituted C4P derivatives (Fig. 4). ${ }^{49-51}$

It is clear from the literature that tetrathiafulvalene (TTF) plays a vital role in diverse areas of science and technology ${ }^{52}$ In this context, Sessler's group attached the TTF moiety at the $\beta$ positions of C4P to generate diverse TTF-C4Ps $(29,31$, and 33), as shown in Schemes 3 and $4 .^{53-57}$

\subsection{Meso-substituted calix $[4]$ pyrroles}

The simple calixpyrrole derivatives can be assembled in a single step in good yields through the condensation of appropriately chosen pyrrole derivatives with suitable ketones; however, for properly meso-substituted calixpyrroles, researchers working in this area generally prefer two-step methods starting from acidic condensation of pyrrole derivatives with appropriate ketones to form substituted dipyrromethanes followed by acid-catalyzed condensation with ketones to achieve the desired targets (Scheme 5).

Recently, Cafeo et al. synthesized functionalised C4P 40 (Scheme 6). After its reaction with cis-[ $\left[\mathrm{PtCl}_{2}\left(\mathrm{DMSO}_{2}\right]\right.$, they obtained a crystalline compound, trans-Pt $\mathbf{4 0}$, which was used to deliver the trans-Pt anticancer drug to the target site. ${ }^{58}$

On the other hand, the same group reported 3,3'-bis(mesoheptamethylC4P)azobenzene $\mathbf{4 2}$ along with its host-guest chemistry with various aliphatic bis-carboxylates (Scheme 7). ${ }^{59}$ 


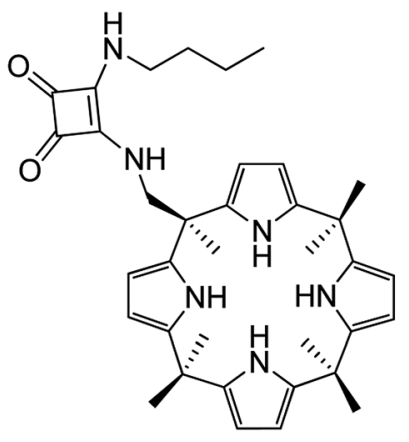

59<smiles>C#Cc1ccc(C#Cc2ccc(C(C)(C)c3ccc(C(C)(C)c4ccc(C(C)(C#Cc5ccc(C#C)cc5)c5ccc(C#C)[nH]5)[nH]4)[nH]3)[nH]2)cc1</smiles>

60<smiles></smiles>

61<smiles></smiles>

63<smiles></smiles>

64

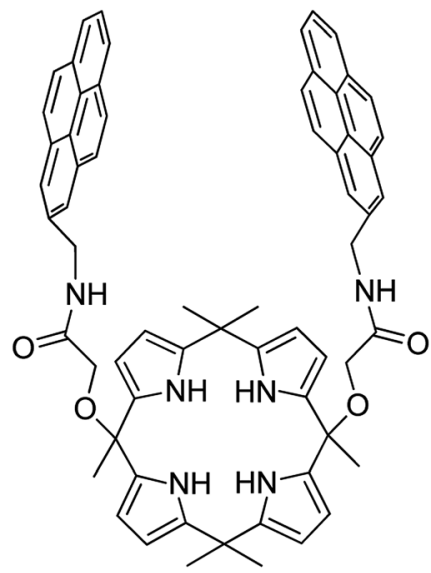

65

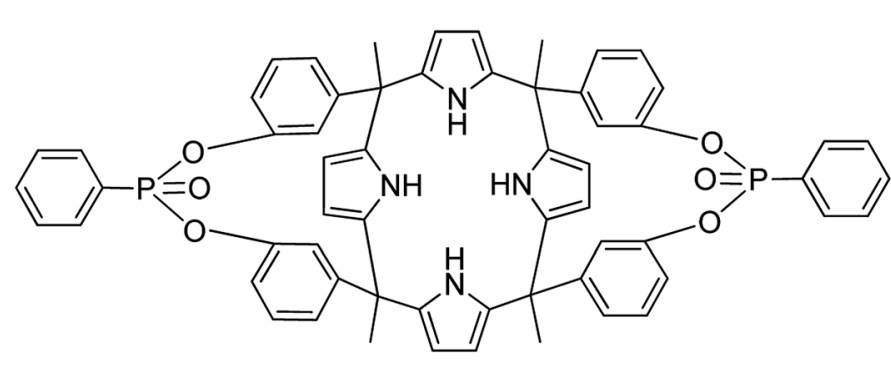

66

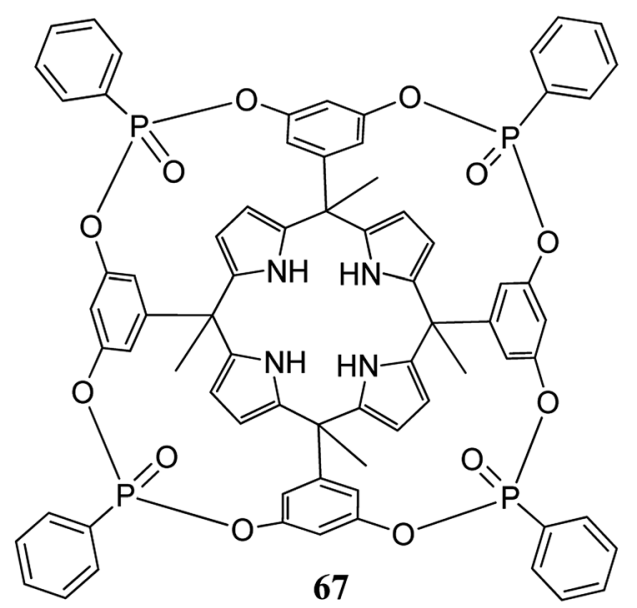

Fig. 6 Structures of various meso-substituted two and four-walled C4Ps.

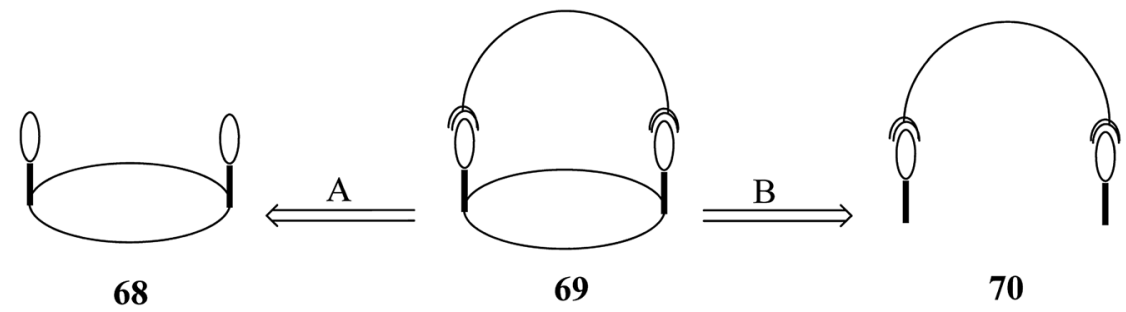

Fig. 7 Retrosynthetic analysis of strapped systems. 
<smiles>CC(CCCO)(c1ccc[nH]1)c1ccc[nH]1</smiles>

71

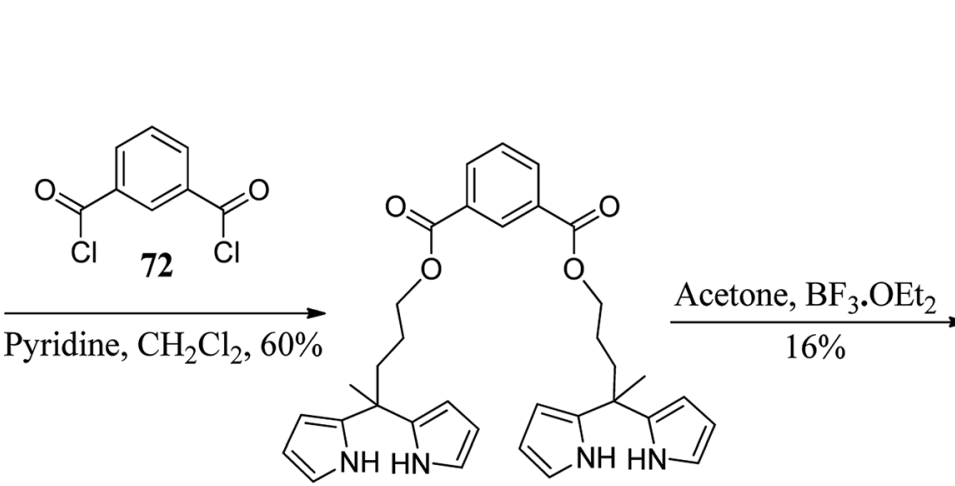

73

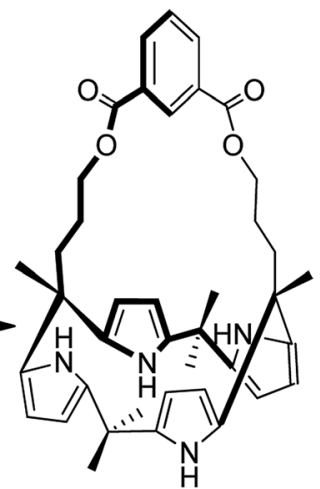

74

Scheme 10 Synthesis of strapped C4P 74

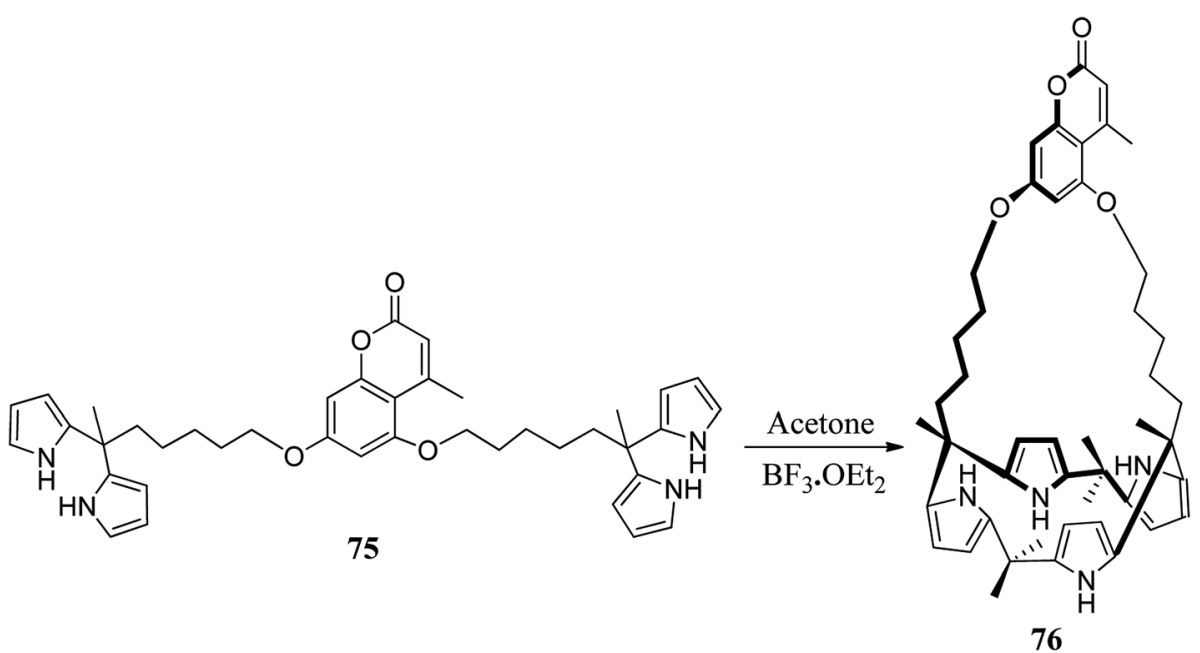

Scheme 11 Synthesis of coumarin-strapped C4P 76.

Recently, Sessler and his teammates synthesized large, capsule-like bis-C4P 46 (Scheme 8). ${ }^{60}$ The capsule 46 possesses a relatively large internal cavity which hosts various oxoanions. ${ }^{61-63}$

Quite recently, Sessler's group synthesised a fluorescent sensor (51) for sensing various aliphatic and aromatic dicarboxylate anions (Scheme 9). It contains the vibrationally induced active 9,14-diphenyl-9,14-dihydrodibenzo[ $a, c]$ phenazine (DPAC) chromophore between two C4P units. ${ }^{64}$

For the exploration of C4Ps in the domain of anion- $\pi$ interactions, in 2013, Ballester's and Matile's groups designed and synthesized meso-substituted two-walled aryl extended C4Ps for the binding of nitrate anion (Fig. 5), thereby highlighting the potential roles being played by different aryl- $\pi$ substituents in anion- $\pi$ contact. ${ }^{3,65,66}$ Researchers worldwide have also carried out the synthesis of various other mesosubstituted two and four-walled C4Ps (Fig. 6). ${ }^{67-81}$

\subsection{Strapped calix $[4]$ pyrroles}

The chemistry of strapped C4Ps has thrived in the past several years. ${ }^{82}$ For the synthesis of strapped C4P-based receptors, two different pathways appear to be very suitable. These include primary construction of the $\mathrm{C} 4 \mathrm{P}$ central loop followed by bridging with a strap (Fig. 7, path A) and initial formation of an associated precursor followed by C4P loop construction (Fig. 7, path $\mathrm{B}$ ); however, it is the second path which has been found to be most effective and is generally adopted for the synthesis of strapped C4Ps.

In 2003, Lee et al. synthesized strapped C4P 74 by means of $[2+2]$ condensation of dipyrromethane $\mathbf{7 1}$ with isophthaloyl 


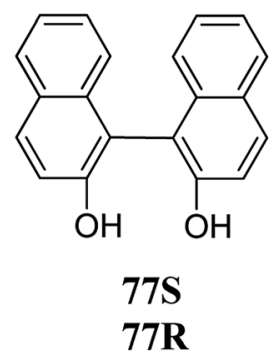<smiles>CC(=O)CCCCBr</smiles>

\section{$\underset{\text { Pyrrole, TFA }}{\stackrel{\mathrm{K}_{2} \mathrm{CO}_{3}, \mathrm{DMF}}{\longrightarrow}}$}

$79 R$

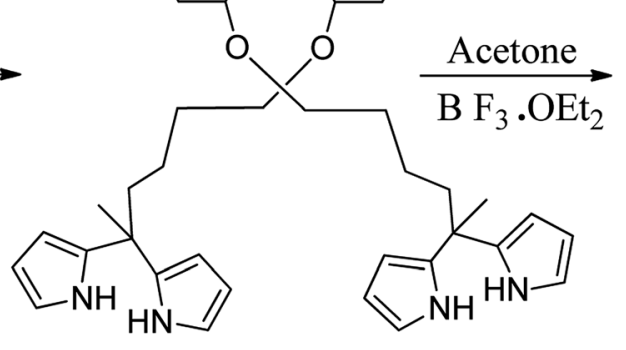

$79 S$

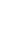

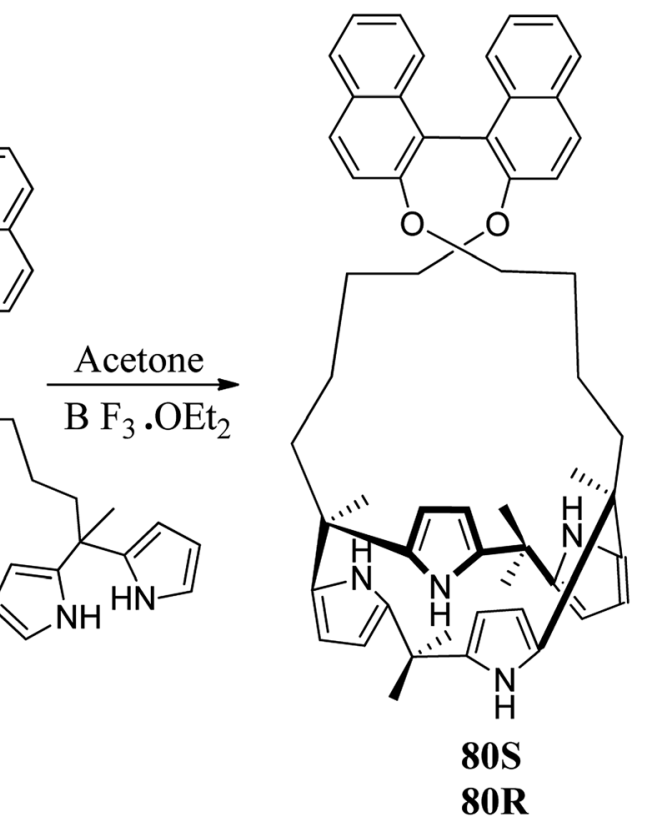

Scheme 12 Synthesis of chiral binol strapped C4Ps $80(R)$ and $80(S)$

chloride (Scheme 10).$^{83}$ On the other hand, in 2005, Miyaji et al. synthesized a new fluorophore-strapped C4P (76) via the dipyrromethane 75 (Scheme 11). ${ }^{84}$

Sessler and coworkers synthesized a pair of chiral C4Ps, $\mathbf{8 0}(R)$ and $80(S)$, which may be extremely useful in the recognition and removal of a variety of anions containing enantiomeric species (Scheme 12). ${ }^{85}$

On another occasion, Jaeduk Yoo et al. reported the synthesis of dipyrrolylquinoxaline-strapped C4P 85 (Scheme 13). ${ }^{86}$ In addition to the above strapped C4P-based receptors, researchers worldwide have carried out the synthesis of other novel strapped C4P receptors (Fig. 8). ${ }^{84-98}$

\section{Applications of functionalized calix [4]pyrroles}

Calix[4]pyrrole, since being reconstructed and studied by Sessler's group in 1996, has made significant contributions to supramolecular chemistry; its diverse applications range from sensory materials to drug delivery (Fig. 9). Considering its activities and applications in different areas of day-to-day life, C4P has earned fame not only in the supramolecular community but also in other branches of science, such as polymer chemistry and catalysis. We therefore believe that this old-yet-new member of the supramolecular family will<smiles>CC(=O)CCc1ccc(C(=O)C(=O)c2ccc(CCC(C)=O)[nH]2)[nH]1</smiles>

Scheme 13 Synthesis of dipyrrolylquinoxaline-strapped C4P 85. 

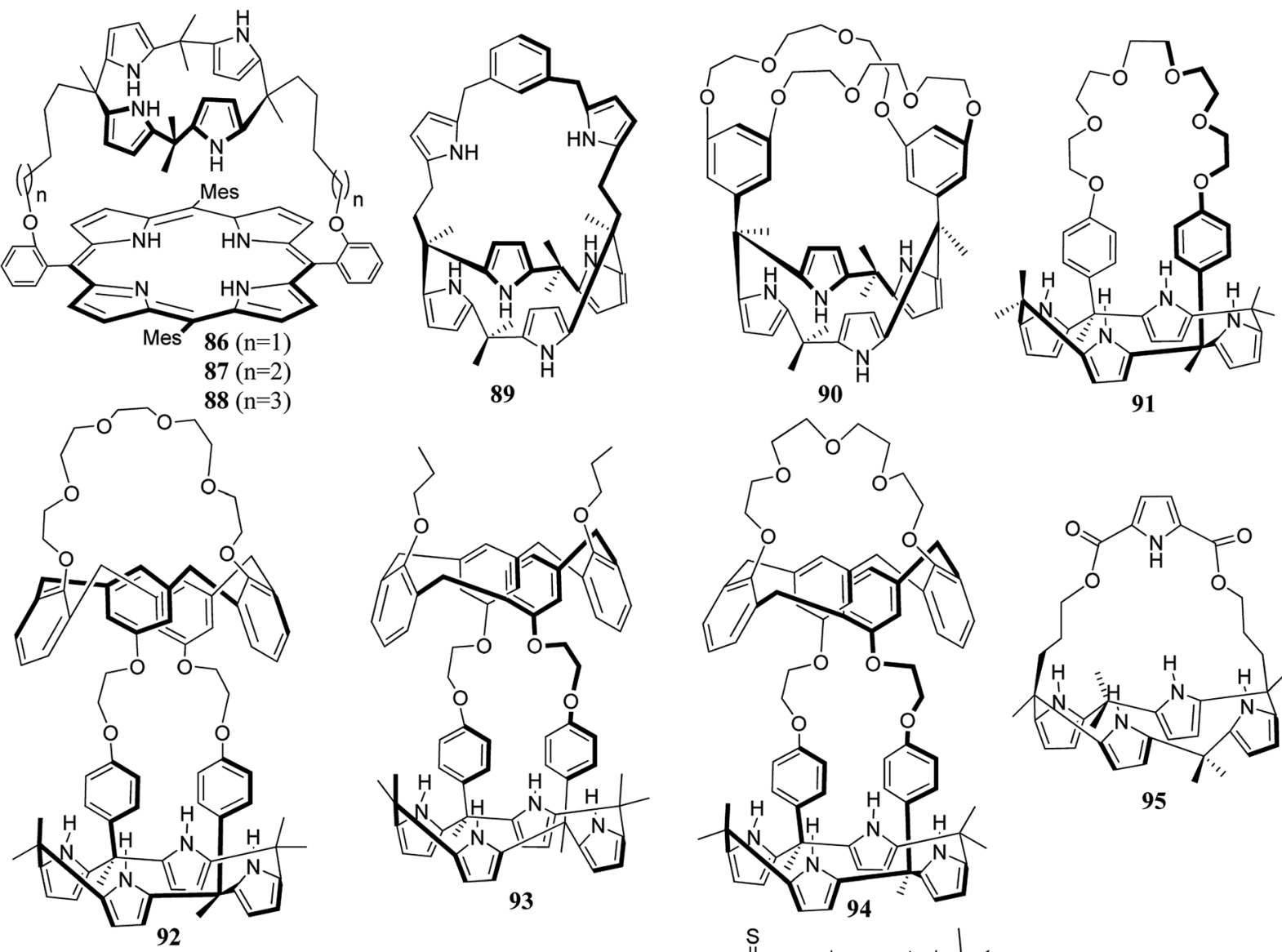

90
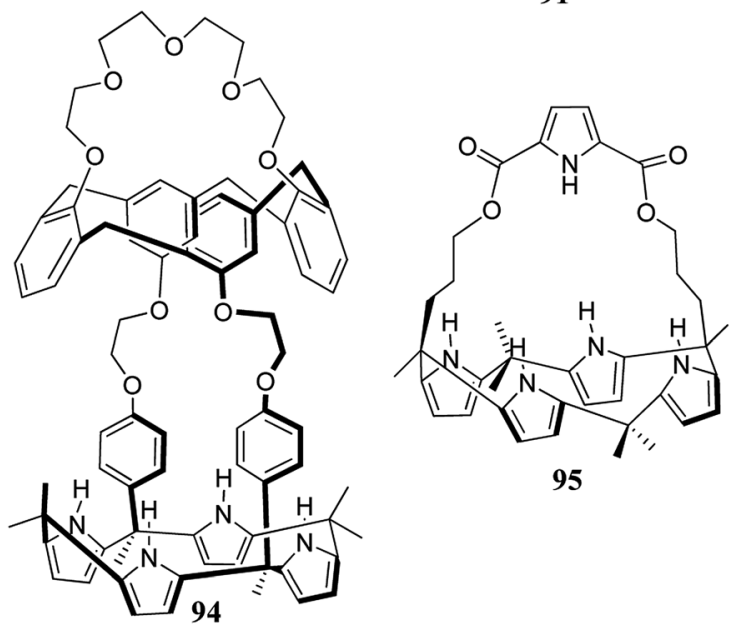

93
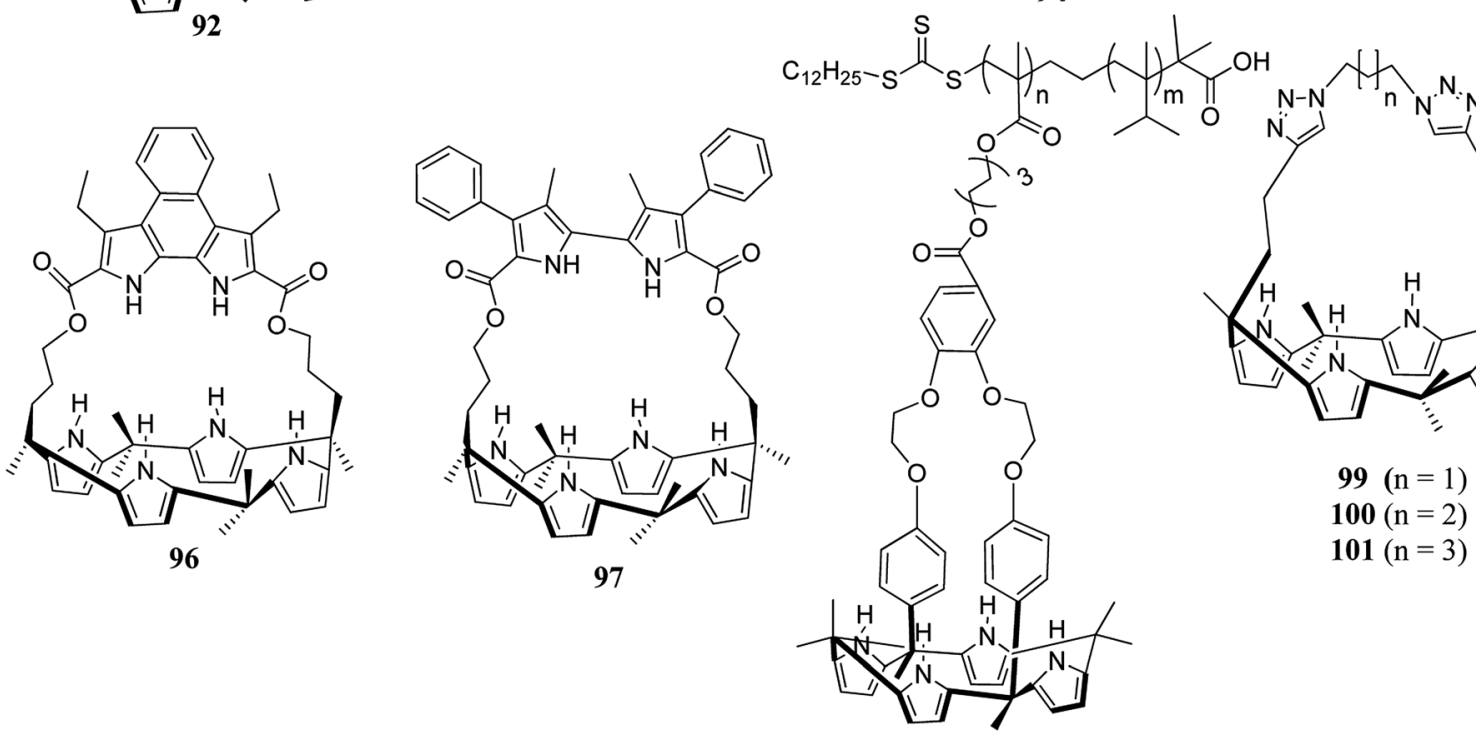

98

Fig. 8 Structures of various interesting strapped C4Ps.

provide a new direction to branches of science and technology. In this comprehensive review, we are highlighting the applications of this supramolecular receptor, as depicted below in Fig. 9.

\subsection{Role of calix[4]pyrroles in anion binding}

Anions play vital roles in biological processes because they take part in $70 \%$ of all enzymatic events. Hence, in recent years, "anion complexation and recognition" has emerged as 


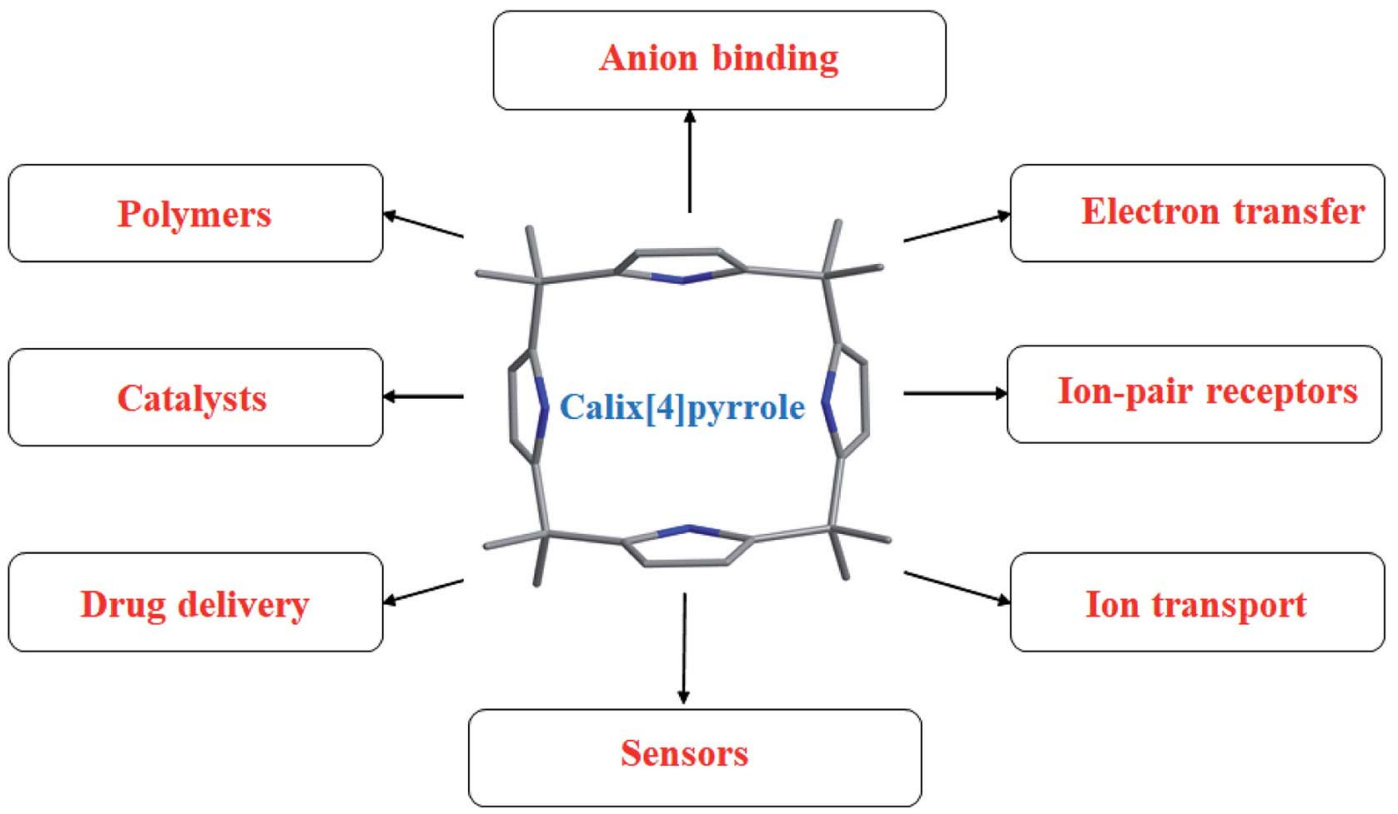

Fig. 9 Flowchart showing the applications of simple C4P and its derivatives.

a topic of leading importance in the realm of supramolecular chemistry. ${ }^{\mathbf{9 9 , 1 0 0}}$ To construct synthetic anion receptors, diverse non-covalent interactions such as halogen bonding, van der Waals forces, dipole-anion interactions, multiple hydrogen bonding, cation $-\pi$ contacts, anion $-\pi$ contacts, and hydrophobic contacts have been employed. ${ }^{101-103}$ Among these, anion $-\pi$ non-covalent contacts (interaction of anionic entities with electron-deficient arene systems), reported around a decade ago, have become an actively investigated area in the heart of supramolecular chemistry ${ }^{\mathbf{1 0 4 - 1 0 7}}$ and have opened new opportunities for the design and synthesis of various novel sensors. ${ }^{\text {108-117 }}$ In this context, Ballester and coworkers observed that cis-3,5-dinitrophenyl functionalized C4P 56 displays selective binding of $\mathrm{NO}_{3}{ }^{-}$by means of hydrogen bonding and anion- $\pi$ interactions. X-ray crystallographic analysis elucidated that the nitrate anion in the form of tetramethylammonium nitrate $\left(\mathrm{TMANO}_{3}\right)$ resides in a perpendicular orientation to the 3,5-dinitrophenyl rings of cis-3,5-dinitrophenyl-functionalized C4P 56 (Fig. 10). ${ }^{33}$

Recently, Park and his teammates reported the complete solid-state analysis of cis-3,5-dinitrophenyl-functionalized C4P 56 with various polyatomic oxyanions along with spherical anions (halides). They also compared the anion binding affinities of the cis-isomer (56) with the trans-isomer (57) and concluded that the cis-isomer shows better results than the trans-isomer, as expected. The results obtained clearly indicate that all examined anions reside within the cavity irrespective of their size and geometry, as can be inferred from Fig. 11. All halides with $1: 1$ stoichiometry were found to be situated in the cavity via four concerted $\mathrm{NH}^{-} \mathrm{X}^{-}$hydrogen bonding interactions, while trigonal anions such as $\mathrm{NO}_{3}{ }^{-}$, $\mathrm{HCO}_{3}{ }^{-}$, and $\mathrm{AcO}^{-}$reside nearly parallel to the two dinitrophenyl rings; this displays a sharp contrast to Ballester's report, which showed a perpendicular orientation of $\mathrm{TMANO}_{3}$

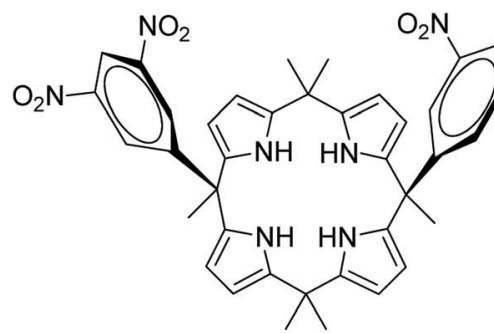

56

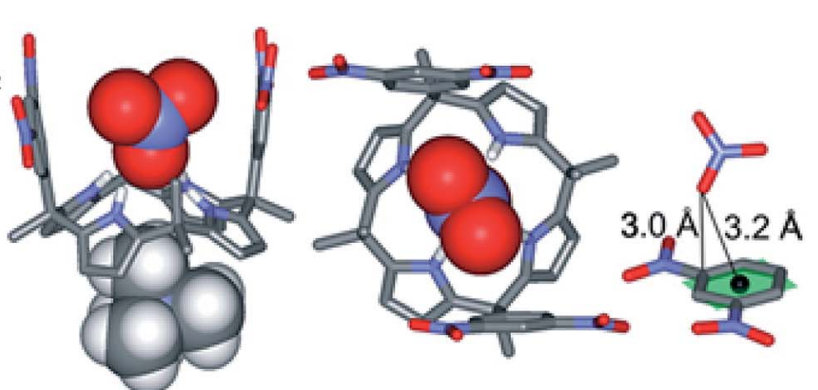

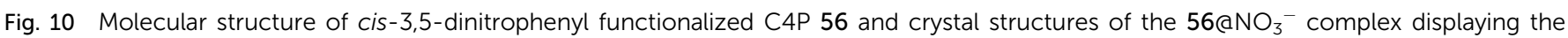
perpendicular orientation of $\mathrm{NO}_{3}^{-}$to the 3,5-dinitrophenyl rings (reproduced and adapted with permission from ref. 33. Copyright 2013 American Chemical Society). 
<smiles></smiles>

56

Cis-isomer

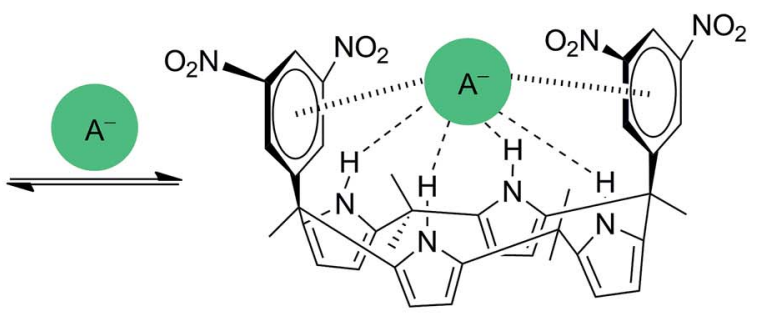

102

Sandwich anion- $\pi$ interaction

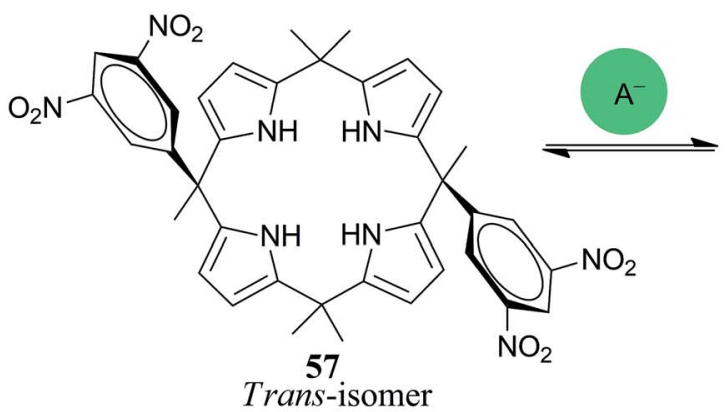

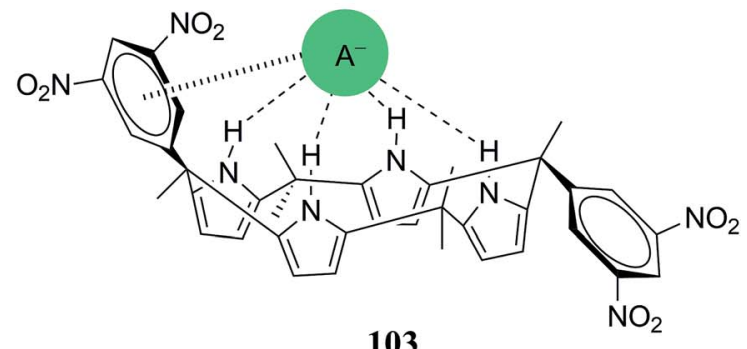

103

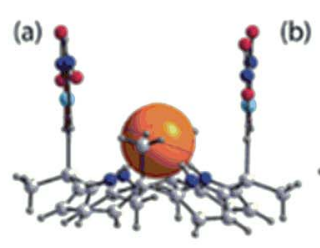

(e)



(f)

(g)
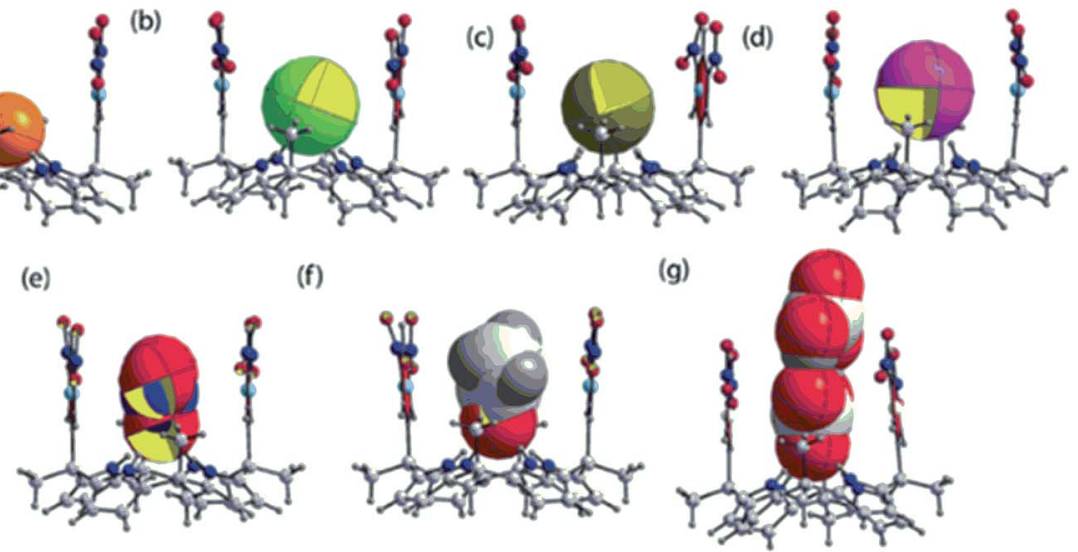

(h)

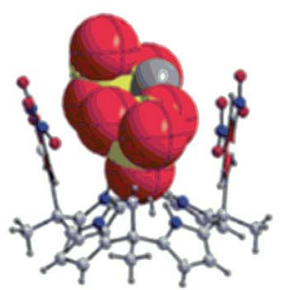

(i)

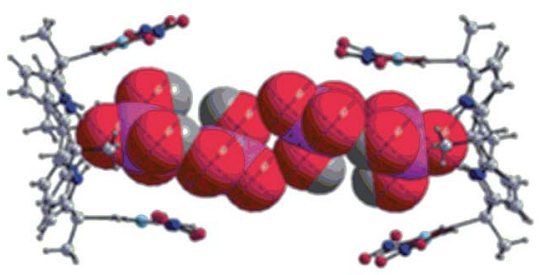

Fig. 11 Representations of hydrogen bonding and anion- $\pi$ interactions in cis- and trans-3,5-dinitrophenyl functionalized C4Ps (56 and 57) along with X-ray analysis of the assemblies between 56 and tetraalkylammonium anion salts: (a) $56+$ TBAF, (b) $56+$ TBACl, (c) $56+$ TBABr, (d) 56


lammonium groups are omitted for simplicity (reproduced with permission from ref. 118. Copyright 2016 Royal Society of Chemistry).

in the cis-3,5-dinitrophenyl functionalized C4P (56). Interestingly, 1:2 stoichiometry was observed in the solid-state between 56 and anions such as $\mathrm{HCO}_{3}{ }^{-}$and $\mathrm{HSO}_{4}{ }^{-}$, and $2: 4$ stoichiometry was observed for $\mathrm{H}_{2} \mathrm{PO}_{4}{ }^{-}$. Using UV-Vis photometric titrations, they also investigated the binding properties of 56 and 57 in the solution state (Table 1). With the aid of Job plot analysis in acetonitrile solution, it was clarified that all the anions show 1:1 stoichiometry, where the binding constants of the cis-isomer (56) were higher than those of the trans-isomer (57); this clearly indicates favourable sandwich- 
Table 1 Binding constants (using UV-Vis titrations) of 1, 56 and 57 for various anions

\begin{tabular}{lllll}
\hline Anion & $\mathbf{1}\left(K_{\mathrm{a}}, \mathrm{M}^{-1}\right)$ & $\mathbf{5 6}\left(K_{\mathrm{a} 1}, \mathbf{M}^{-1}\right)$ & $\mathbf{5 7}\left(K_{\mathrm{a} 2}, \mathbf{M}^{-1}\right)$ & $K_{\mathrm{a} 1} / K_{\mathrm{a} 2}$ \\
\hline $\mathrm{F}^{-}$ & - & $2.1 \times 10^{7}$ & $7.2( \pm 4.4) \times 10^{6}$ & 3 \\
$\mathrm{TEACl}^{-}$ & - & $1.8( \pm 0.09) \times 10^{6}$ & $3.6( \pm 0.08) \times 10^{4}$ & 50 \\
$\mathrm{TBACl}^{-}$ & $1.02 \times 10^{5}$ & $1.9( \pm 0.2) \times 10^{6}$ & $1.1( \pm 0.05) \times 10^{5}$ & 17 \\
$\mathrm{THACl}^{-}$ & - & $2.5( \pm 0.2) \times 10^{6}$ & $1.5( \pm 0.14) \times 10^{5}$ & 17 \\
$\mathrm{Br}^{-}$ & $1.05 \times 10^{3}$ & $5.4( \pm 0.04) \times 10^{4}$ & $3.0( \pm 0.04) \times 10^{3}$ & 18 \\
$\mathrm{I}^{-}$ & - & $300( \pm 1)$ & $10( \pm 0.1)$ & 30 \\
$\mathrm{NO}_{3}{ }^{-}$ & - & $1500( \pm 6)$ & $80( \pm 1)$ & 19 \\
$\mathrm{AcO}^{-}$ & $2.17 \times 10^{5}$ & $1.4 \times 10^{7}$ & $1.5( \pm 0.25) \times 10^{6}$ & 9 \\
$\mathrm{HCO}_{3}^{-}$ & - & $2.1 \times 10^{6}$ & $8.0( \pm 0.6) \times 10^{4}$ & 66 \\
$\mathrm{HSO}_{4}{ }^{-}$ & - & $1700( \pm 6)$ & $20( \pm 0.4)$ & 85 \\
$\mathrm{H}_{2} \mathrm{PO}_{4}{ }^{-}$ & $2.65 \times 10^{3}$ & $5.9 \times 10^{6}$ & $1.6(0.07) \times 10^{4}$ & 369 \\
& & & &
\end{tabular}

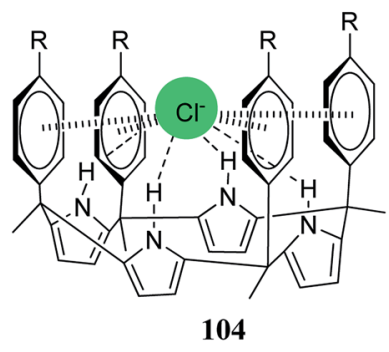

$\left[\begin{array}{lc}\mathbf{R} & \mathbf{K a ~}\left(\mathbf{M}^{\mathbf{1}}, \mathbf{C D}_{\mathbf{3}} \mathbf{C N}\right) \\ \hline \mathrm{OMe} & 1.3 \times 10^{2} \\ \mathrm{H} & 2.5 \times 10^{2} \\ \mathrm{Br} & 3.8 \times 10^{2} \\ \mathrm{CN} & 3.3 \times 10^{2} \\ \mathrm{NO}_{2} & 1.8 \times 10^{2}\end{array}\right]$

Fig. 12 Representation of hydrogen bonding and anion $-\pi$ contacts with the meso-tetraaryl $\mathrm{C} 4 \mathrm{P}$ receptor and their association constants with chloride in $\mathrm{CD}_{3} \mathrm{CN}$.

type anion- $\pi$ interactions. It was also found that the cis- and trans-isomers show visible colour changes after the addition of some anions, viz. fluoride anion addition produces a drastic colour change from yellow to blue, and these changes were accompanied by spectral changes. Thus, anion$\pi$ interactions in the case of electron-deficient 3,5dinitrophenyl-substituted C4P leads to the development of chromogenic materials. ${ }^{\mathbf{1 1 8}}$

Ballester and coworkers also reported binding energy studies of meso-substituted four-walled (tetraaryl) $\mathrm{C} 4 \mathrm{P}$ receptor $\mathbf{1 0 4}$ (Fig. 12) with chloride in the solution phase and finally quantified the chloride- $\pi$ interactions. ${ }^{1} \mathrm{H}-\mathrm{NMR}$ and X-ray

Table 2 Binding constants of trans -42 and cis- 42 with bis-carboxylates (as TBA salts)

\begin{tabular}{lll}
\hline bis-Carboxylate & $K_{\mathrm{a}}$ for tans-42 & $K_{\mathrm{a}}$ for cis-42 \\
\hline Succinate & $6.4 \times 10^{3}$ & $5.3 \times 10^{5}$ \\
Glutarate & $7.4 \times 10^{4}$ & $2.2 \times 10^{5}$ \\
L-Glutamate & $2.7 \times 10^{3}$ & Not determined \\
Adipate & $8.6 \times 10^{4}$ & $2.2 \times 10^{4}$
\end{tabular}

Table 3 Binding constants of receptor 31 with different anions using ITC in $\mathrm{CH}_{2} \mathrm{ClCH}_{2} \mathrm{Cl}$

\begin{tabular}{ll}
\hline Anion & $31\left(K_{\mathrm{a}} \mathrm{M}^{-1}\right)$ \\
\hline $\mathrm{Cl}^{-}$ & $2.5 \times 10^{6}$ \\
$\mathrm{Br}^{-}$ & $5.8 \times 10^{4}$ \\
$\mathrm{CN}^{-}$ & $1.1 \times 10^{6}$ \\
$\mathrm{NO}_{2}{ }^{-}$ & $1.2 \times 10^{6}$ \\
$\mathrm{CH}_{3} \mathrm{CO}_{2}{ }^{-}$ & $1.3 \times 10^{6}$ \\
\hline
\end{tabular}

Table 4 Association constants $\left(K_{\mathrm{a}}\right)$ of 76 with various anions in different solvents $\left(3 \% \mathrm{H}_{2} \mathrm{O}-\mathrm{CH}_{3} \mathrm{CN}, \mathrm{NaPF}_{6}-\mathrm{CH}_{3} \mathrm{CN}\right.$, and $\left.\mathrm{CH}_{3} \mathrm{CN}\right)$ at $298 \mathrm{~K}$

\begin{tabular}{lccr}
\hline & \multicolumn{3}{c}{$10^{-4}\left(K_{\mathrm{a}}, \mathrm{M}^{-1}\right)$} \\
\cline { 2 - 4 } Anion source & $3 \% \mathrm{H}_{2} \mathrm{O}-\mathrm{CH}_{3} \mathrm{CN}$ & $\mathrm{NaPF}_{6}-\mathrm{CH}_{3} \mathrm{CN}$ & $\mathrm{CH}_{3} \mathrm{CN}$ \\
\hline TBACl & 190 & 230 & 360 \\
TBABr & 3.7 & 10 & 11 \\
TBAOAc & 89 & 130 & 190
\end{tabular}

crystallographic analysis was employed to demonstrate the interactions between the electronically tunable cavity of the receptor and the chloride ion. The required association constants of $\mathbf{1 0 4}$ with diverse anions were calculated in the solution phase $\left(\mathrm{CD}_{3} \mathrm{CN}\right)$, as can be seen by inspection of Fig. $12 .{ }^{119}$

Cafeo et al. observed that the complexation of 3,3'-bis(mesoheptamethylC4P)azobenzene receptor 42 (Scheme 7) with diverse bis-carboxylates has considerable kinetic effects on both the thermal and photochemical trans/cis isomerization of the azobenzene unit. They carried out binding constant evaluations of both the cis- and trans-forms of $\mathbf{4 2}$ with various biscarboxylates (Table 2). ${ }^{59}$

Regarding the anion-binding studies of $\beta$-substituted C4Ps, Sessler and his teammates carried out replacement of the $\beta$ pyrrolic protons with complex substituents. ${ }^{120}$ They designed and synthesized various TTF-C4Ps and other oligopyrrolic macrocycles. ${ }^{55,121-126}$ They utilized TTF-based C4P 31 (Scheme 4) and carried out anion binding studies with diverse anions such

Table 5 Calculated $K_{a}$ values of receptor 85 with diverse anions carried out in $\mathrm{CH}_{3} \mathrm{CN} / \mathrm{DMSO}$ at $25^{\circ} \mathrm{C}$

\begin{tabular}{llll}
\hline Anion & UV-Vis $\left(K_{\mathrm{a}}, \mathrm{M}^{-1}\right)$ & $\mathrm{ITC}\left(K_{\mathrm{a}}, \mathrm{M}^{-1}\right)$ & $\mathrm{C} 4 \mathrm{P}\left(K_{\mathrm{a}}, \mathrm{M}^{-1}\right)$ \\
\hline $\mathrm{F}^{-}$ & $8.97 \times 10^{6}$ & $K_{1}=3.72 \times 10^{8}$ & Not available \\
& & $K_{2}=5.0 \times 10^{5}$ & \\
$\mathrm{Cl}^{-}$ & $1.09 \times 10^{4}$ & $1.94 \times 10^{4}$ & $1.02 \times 10^{5}$ \\
$\mathrm{Br}^{-}$ & $3.65 \times 10^{2}$ & Not determined & $1.05 \times 10^{3}$ \\
$\mathrm{AcO}^{-}$ & $8.12 \times 10^{3}$ & $1.89 \times 10^{4}$ & $2.17 \times 10^{5}$ \\
$\mathrm{H}_{2} \mathrm{PO}_{4}{ }^{-}$ & $1.13 \times 10^{3}$ & $1.33 \times 10^{3}$ & $2.65 \times 10^{3}$
\end{tabular}




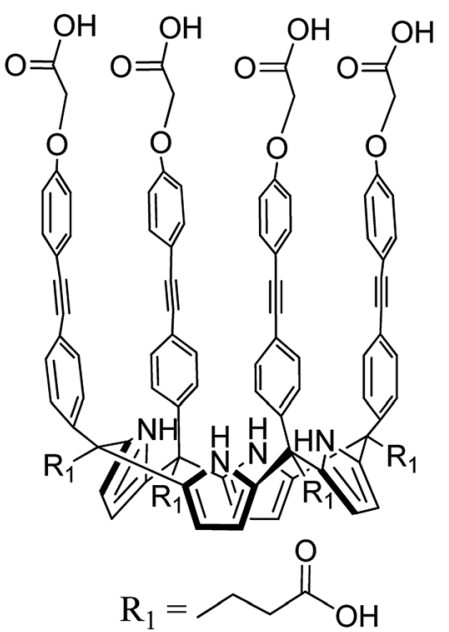

105

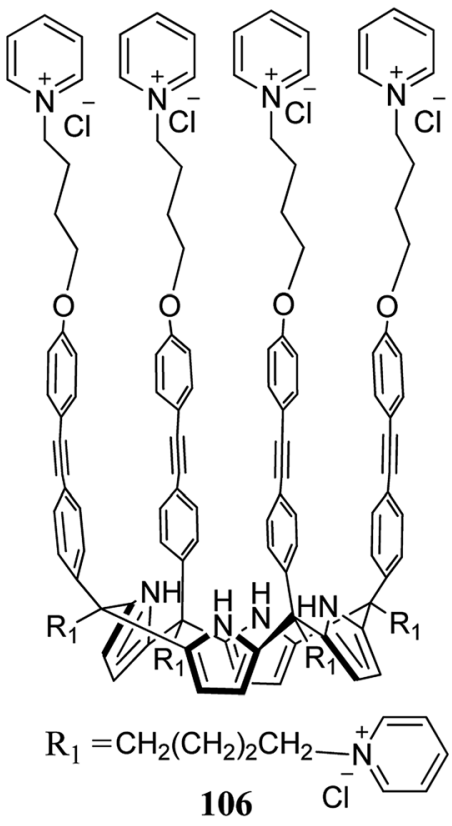



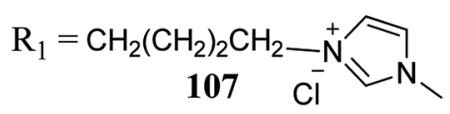<smiles>[O-][n+]1ccc(-c2ccccc2)cc1</smiles>

108

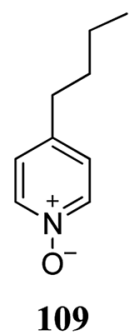

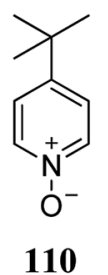<smiles>Cc1cc[n+]([O-])cc1</smiles><smiles>[O-][n+]1ccccc1</smiles>

112<smiles>[O-][n+]1ccc2ccccc2c1</smiles>

113

Fig. 13 Molecular structures of super aryl-extended C4P hosts (105-107) and pyridyl N-oxide guests (108-113).

as $\mathrm{Br}^{-}, \mathrm{Cl}^{-}, \mathrm{CN}^{-}, \mathrm{NO}_{2}{ }^{-}$, and $\mathrm{AcO}^{-}$by means of ${ }^{1} \mathrm{H}-\mathrm{NMR}$ spectroscopy and isothermal titration calorimetry (ITC) techniques (Table 3). ${ }^{52-57}$

Regarding the anion binding significance of strapped C4Ps, researchers worldwide have employed various strapped C4Ps in the binding of diverse anions. In this context, Lee et al. carried out anion binding studies of a host, 74 (Scheme 10), and confirmed that chloride anion rests inside the cavity. ${ }^{83}$ The chloride complex of $\mathbf{7 4}$ also reveals that the aryl $\mathrm{CH}$ participates in anion recognition in terms of hydrogen bonding. With the

Table 6 Binding constants of 105 and 106 with polar guests (108-113) using ITC and ${ }^{1} \mathrm{H}-\mathrm{NMR}$ titrations

\begin{tabular}{lll}
\hline Polar guest & $K_{\mathrm{a}}$ for 105 & $K_{\mathrm{a}}$ for 106 \\
\hline $\mathbf{1 0 8}$ & $1.2 \pm 0.5 \times 10^{9}$ & $2.6 \pm 0.6 \times 10^{9}$ \\
$\mathbf{1 0 9}$ & $1.0 \pm 0.4 \times 10^{8}$ & $3.7 \pm 0.6 \times 10^{8}$ \\
$\mathbf{1 1 0}$ & $9.1 \pm 3.0 \times 10^{6}$ & $3.7 \pm 0.6 \times 10^{7}$ \\
$\mathbf{1 1 1}$ & $2.0 \pm 0.1 \times 10^{6}$ & $6.1 \pm 0.1 \times 10^{6}$ \\
$\mathbf{1 1 2}$ & $8.6 \pm 0.5 \times 10^{5}$ & $1.9 \pm 0.1 \times 10^{6}$ \\
$\mathbf{1 1 3}$ & $2.2 \pm 0.2 \times 10^{7}$ & $7.1 \pm 0.2 \times 10^{6}$
\end{tabular}

aid of ITC calculations, they also observed that strapped C4P 74 has a higher binding constant for chloride anion $\left(K_{\mathrm{a}}=1.01 \times\right.$ $\left.10^{5}\right)$ than unstrapped C4P $\left(K_{\mathrm{a}}=1.2 \times 10^{3}\right)$. Thus, it is the shape and size of C4Ps which determine the enhanced anion selectivity of the anion receptors. ${ }^{\mathbf{8 4 , 8 7 - 9 4}}$

Miyaji et al. determined the association constants of coumarin-strapped C4P receptor 76 (Scheme 11) with various anions by means of fluorescence and ITC titrations (Table 4). ${ }^{\mathbf{8 4}}$ On the other hand, Sessler and teammates revealed that chiral C4P 80(S) (Scheme 12) exhibits high affinity to bind chiral carboxylate anions, viz. (R)-2-phenylbutyrate and (S)-2-phenylbutyrate, in acetonitrile. The $(S)$-guest- $(S)$-host pair possesses $K_{\mathrm{a}}$ values 10 times greater than those of the analogous $(R)$-guest$(S)$-host pair. ${ }^{85}$ On another occasion, Jaeduk Yoo et al. carried out anion binding studies of dipyrrolylquinoxaline-based strapped C4P 85 (Scheme 13) with $\mathrm{F}^{-}, \mathrm{Cl}^{-}, \mathrm{Br}^{-}, \mathrm{AcO}^{-}$, and $\mathrm{H}_{2} \mathrm{PO}_{4}{ }^{-}$by means of UV-Vis absorption spectra in $\mathrm{CH}_{3} \mathrm{CN}$ / DMSO and ITC (Table 5). ${ }^{86}$

The solubility of C4Ps in aqueous media is a challenging aspect which was recently overcome by Ballester and coworkers. They reported various water-soluble super aryl-extended C4Ps 

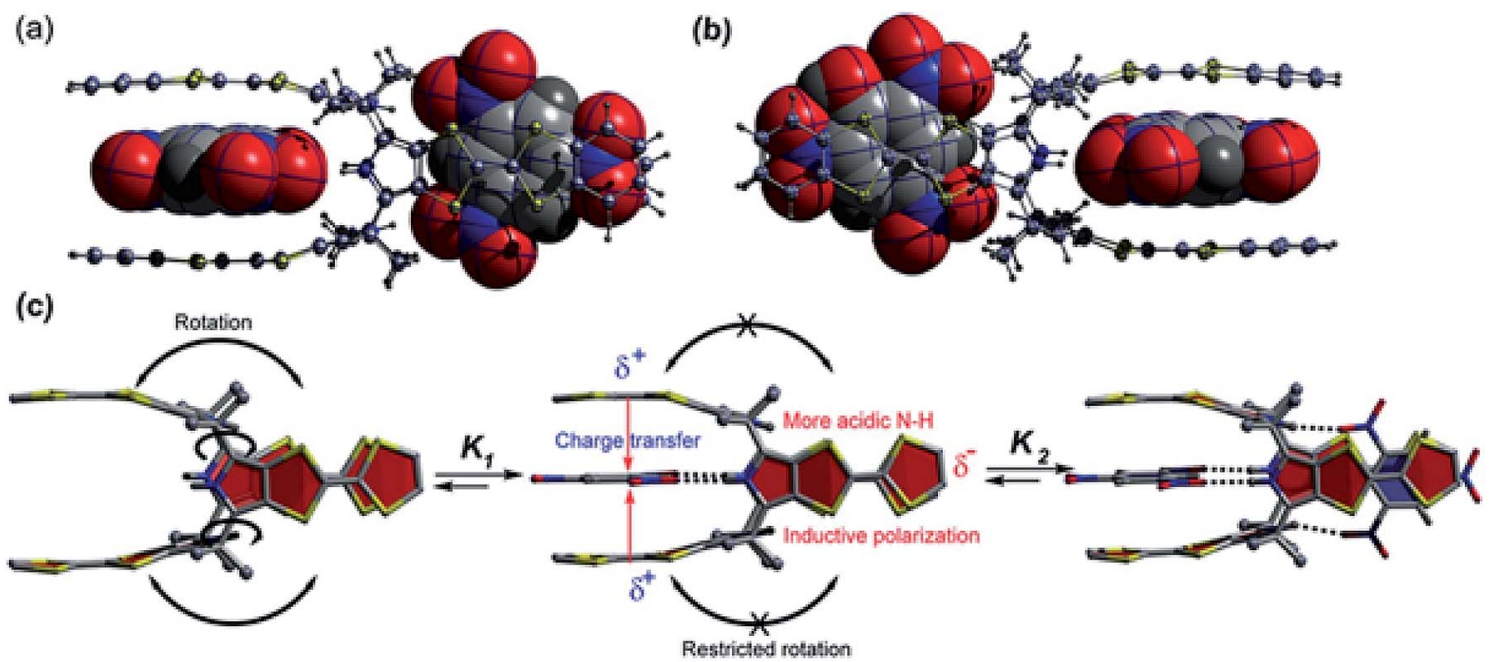

Fig. 14 X-ray studies of (a) TNB2 $\subset 29$ and (b) TNP2 $\subset 29$ and (c) illustration of positive homotropic cooperative binding (reproduced with permission from ref. 56. Copyright 2018 American Chemical Society).

(a)

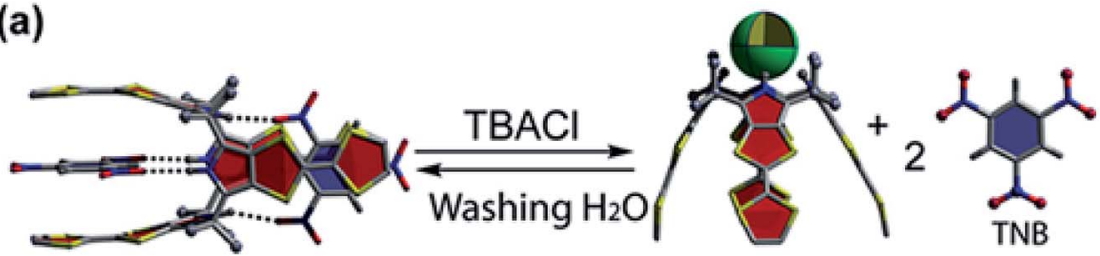

CT

No-CT

(b)

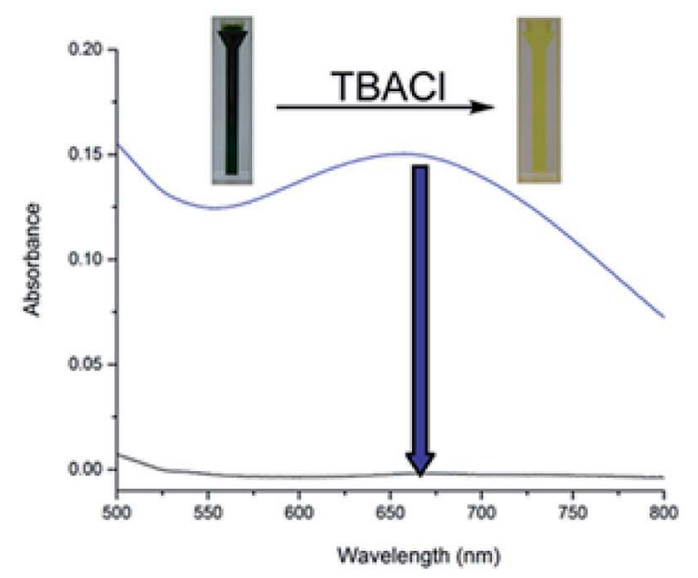

Fig. 15 Switching between TNB2 $\subset 29$ and its fundamental elements in terms of chloride. (b) Absorption spectral changes (reproduced with permission from ref. 56. Copyright 2018 American Chemical Society).

(105-107) for the binding of polar pyridyl $N$-oxides (108-113) in water (Fig. 13). ${ }^{127}$ These super aryl-extended C4Ps form 1:1 stable complexes with polar guests in water and offer larger binding constants (Table 6). It has also been observed that the thermodynamic stability of $1: 1$ complexes is enhanced by increasing the surface area of the non-polar substituents at the para positions of pyridyl $N$-oxides (Fig. 13). With the aid of these non-polar residues, they quantified the hydrophobic effects in the cavities of these systems by means of ITC and ${ }^{1} \mathrm{H}-\mathrm{NMR}$ titrations. This effect plays a prominent role in the binding of polar guests, with assistance from dispersion and hydrogen bonding interactions. ${ }^{127}$ 



115

Fig. 16 Molecular structures of fluorophore-tethered C4P 114, ionized receptor $114^{-}$and host-guest complex 115.

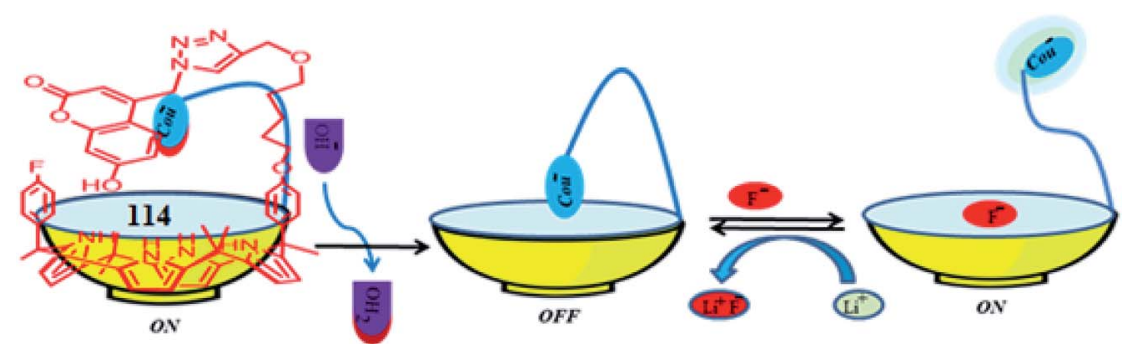

Fig. 17 Schematic illustrating the operative mechanism of fluorescence switching of the receptor 114.

\subsection{Calix[4]pyrroles as sensors}

The rapid search for relatively inexpensive, sensitive and intrinsically selective sensory materials to detect small amounts of nitroaromatic explosives is a significant concern for national as well as global security. To this end, the exponentially increasing demand to enhance the protection of society and to aid the location of hidden land mines has encouraged supramolecular chemists to design novel chemosensors to detect nitroaromatic explosives. In recent years, Sessler's group has synthesized various TTF-C4P-based fluorophores to detect and discriminate diverse highly explosive nitroaromatic<smiles></smiles>

Fig. 18 Functional and ratiometric C4P-based receptor 22 for cyanide anion. 




Fig. 19 UV-Vis changes of the host 22 with cyanide anion (20 equiv.) in $\mathrm{CH}_{3} \mathrm{CN}-\mathrm{DMSO}$ (3\%) (reproduced with permission from ref. 132. Copyright 2009 Royal Society of Chemistry.).

compounds. These fluorophores exhibit positive allosteric behaviour with electron-deficient explosive guests such as 2,4,6trinitrophenol (TNP), 2,4,6-trinitrotoluene (TNT), and 1,3,5-trinitrobenzene (TNB). By virtue of their small sizes, the guests are inserted into 1,3-alternate conformations of 29, 31, and 33 and display $1: 2$ stoichiometry, as confirmed by X-ray diffraction studies (Fig. 14). ${ }^{128}$ The best allosteric behaviour with good agreement of overall binding constants was found in the case of thiophene-TTF-C4P 33, followed by benzo-TTFC4P 29 and S-PrTTF-C4P 31. As far as future perspectives are concerned, we hope that opportunities for supramolecular chemists and biologists will be expanded by manipulating allosteric regulators in order to control and replicate complex biological systems

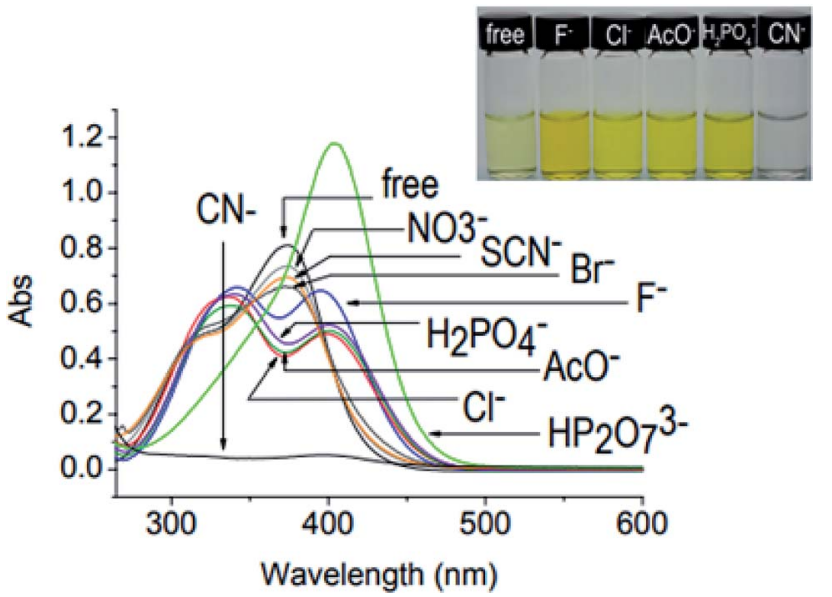

Fig. 20 UV-Vis spectral changes of free host 22 upon addition of diverse anions (20 equiv.) in $\mathrm{CH}_{3} \mathrm{CN}-\mathrm{DMSO}$ (3\%). Color changes of 22 observed in the presence of $\mathrm{F}^{-}, \mathrm{Cl}^{-}, \mathrm{H}_{2} \mathrm{PO}_{4}{ }^{-}, \mathrm{AcO}^{-}$, and $\mathrm{CN}^{-}$are also displayed (reproduced with permission from ref. 132. Copyright 2009 Royal Society of Chemistry). in simple paradigms. Molecular-scale logic devices bearing allosteric functions are thus likely forerunners of modern supramolecular chemistry. ${ }^{129}$

Sessler's group also observed visual colour changes upon mixing TTF-C4Ps with electron-deficient substrates; these colour changes were attributed to the emergence of chargetransfer bands. ${ }^{\mathbf{1 3 0}}$ Complete vanishing of the wide chargetransfer bands was observed on adding tetrabutylammonium chloride to chloroform solutions containing nitroaromatic complexes of TTF-C4P host 29. This occurs by virtue of switching from the 1,3-alternate conformation to the cone conformation, as can be inferred from Fig. $15 .^{128}$ The cone conformation, in sharp contrast to the tweezer-like 1,3-alternate conformation, contains a bowl-shaped cavity that is inappropriate for the binding of small nitroaromatic explosives; as a result, the guests are released into solution. After the salt is eliminated from this mixture by carrying out $\mathrm{H}_{2} \mathrm{O}$ based washing of the organic phase, the chargetransfer complexes are regenerated, as can be inferred from Fig. 15.

In 2016, Lee and coworkers devised a highly selective and sensitive single-molecular ion-mediated fluorescent switching receptor $\mathbf{1 1 4}$ which possesses an appended fluorophore in its structure (Fig. 16). ${ }^{79}$ The fluorescent receptor 114 on treatment with tetrabutylammonium hydroxide (TBAH) undergoes deprotonation very easily, and the resulting solution becomes completely non-fluorescent because the ionized receptor $\mathbf{1 1 4}^{-}$ generates a hydrogen bonding complex with a C4P moiety to form host-guest complex 115 (Fig. 16); upon treatment with $\mathrm{LiF}$, the fluorescence is recovered, as displayed in Fig. 17. They also observed that the fluorescence of the system is turned off again in the presence of metal ion. This is because the hydrogen bonding is disrupted by strong coulombic interactions between the metal ion and receptor-bound anion. Thus, with the aid of external stimuli, the devised system operates efficiently in a sequential "on-off-on-off" manner (Fig. 17). ${ }^{79}$

Although anions perform essential roles in the biological as well as in the physical world, they must be treated with care because some anions are toxic to biosystems. ${ }^{\mathbf{1 3 1}}$ Thus, in order to overcome the poisonous effects of these anions, some synthetic sensors which sense these anions have been designed and synthesized; this can lead to the elimination of toxic effects. Cyanide ion is highly toxic to living animals and is released as unwanted waste from numerous industrial processes, such as gold mining and electroplating, into the environment, leading to serious problems. In this context, in 2009, Chang-Hee Lee and coworkers developed a dual functional and ratiometric sensor 22 with a dicyanovinyl group at the $\beta$-position for the detection of cyanide anion (Fig. 18). ${ }^{132}$ They found that unlike the parent $\beta$-unsubstituted $\mathrm{C} 4 \mathrm{P}$, which is transparent in the visible region, the substituted $\mathbf{2 2}$ is yellow, with a $\lambda_{\max }$ of $374 \mathrm{~nm}$. The receptor 22 acts as an anion-selective ratiometric sensor for cyanide anions by means of a nucleophilic addition reaction, as shown in Fig. 18. They also noted a large 

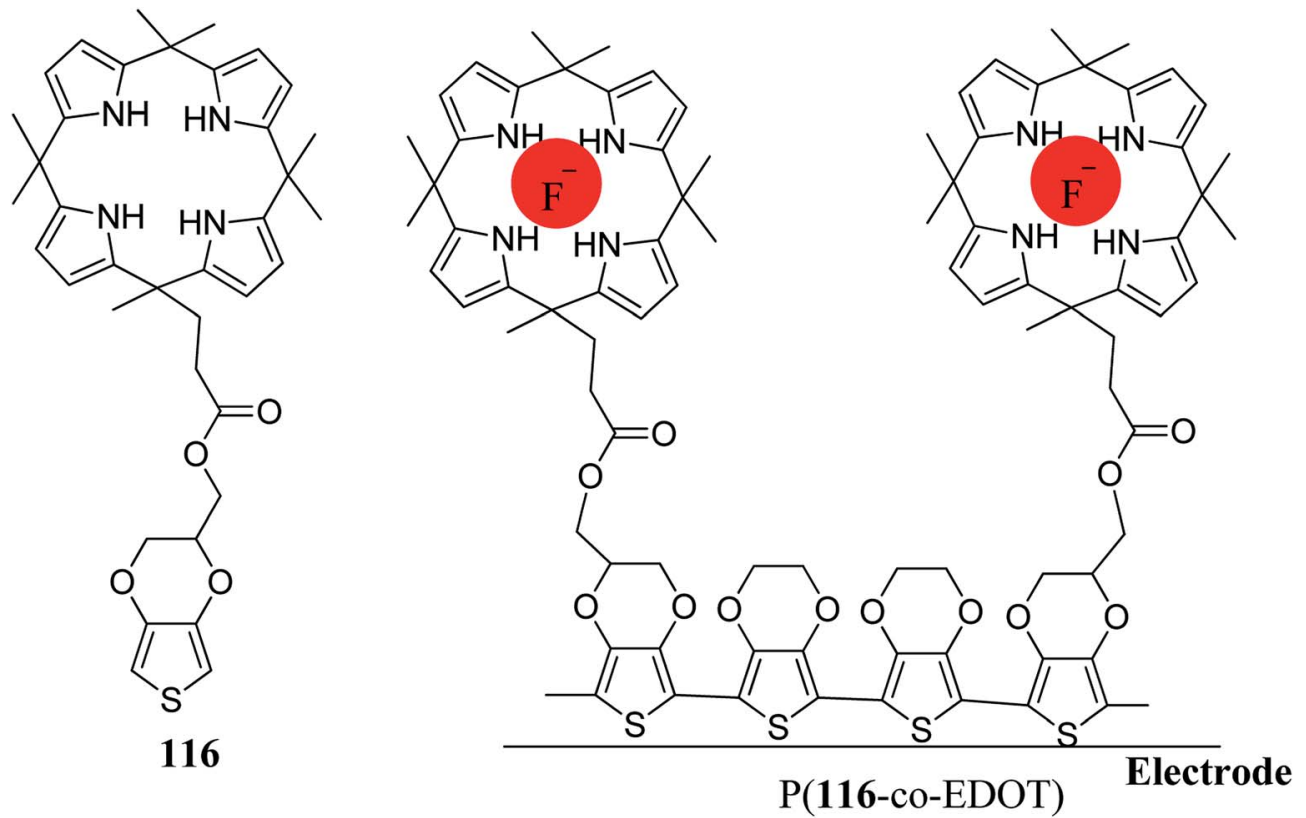

Fig. 21 Structure of 116 and the conductive copolymer P(116-co-EDOT) encapsulating $\mathrm{F}^{-}$.

bathochromic shift from $\lambda_{\max } 374 \mathrm{~nm}$ to $403 \mathrm{~nm}$ in the presence of cyanide anion using time-dependent UV-Vis spectroscopy (Fig. 19). The selective nature of the interaction of cyanide ion with the host 22 was further evaluated by studying the absorption spectral changes in comparison to the other anions, such as $\mathrm{F}^{-}, \mathrm{Cl}^{-}, \mathrm{Br}^{-}, \mathrm{NO}_{3}{ }^{-}, \mathrm{SCN}^{-}, \mathrm{H}_{2} \mathrm{PO}_{4}{ }^{-}, \mathrm{AcO}^{-}$and $\mathrm{HP}_{2} \mathrm{O}_{7}{ }^{-}$ (Fig. 20). ${ }^{132}$

Aydogan et al. reported 3,4-(ethylenedioxy)thiophene (EDOT) functionalized C4P 116 along with its selective electrochemical sensing of fluoride anion in water, as shown in Fig. 21. They also carried out square wave voltammetry of $\mathbf{1 1 6}$ in order to verify the fluoride anion sensing (Fig. 22). ${ }^{133}$

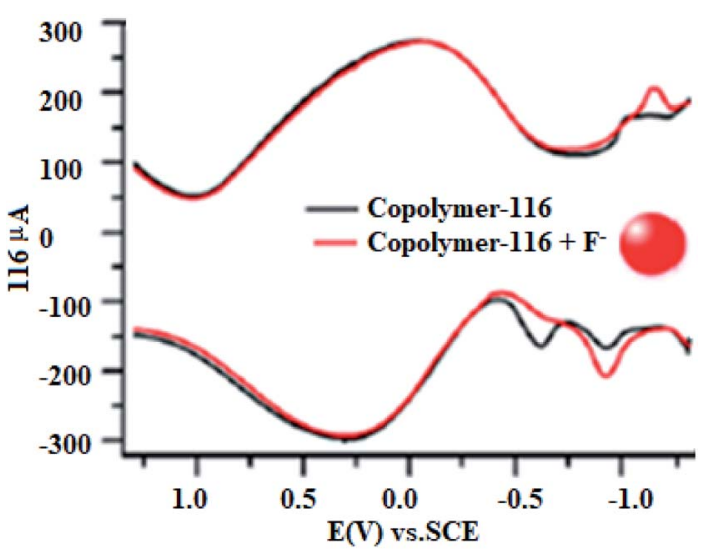

Fig. 22 Square wave voltammetry of ITO/P(116-co-EDOT) with increasing quantities of $\mathrm{F}^{-}$in an $\mathrm{H}_{2} \mathrm{O} / \mathrm{LiClO}_{4}$ electrolyte system (reproduced with permission from ref. 133. Copyright 2014 American Chemical Society).
In another experiment, they developed the sensor 118 from pyrene-linked C4P 117 attached with non-covalent contacts to single-walled carbon nanotubes (SWCNT). The developed sensor was used for the selective sensing of acetone vapors on paper (concentration range 20 to $500 \mathrm{ppm}$ ) (Fig. 23). ${ }^{134}$

On other occasions, C4P has also been used as a chromophore. For example, Sessler and coworkers developed a novel anion sensor for sensing 4-nitrophenolate by virtue of a color change. They observed a prominent colour change in tetrabutylammonium-4-nitrophenolate from yellow to colourless upon the addition of $\mathrm{C} 4 \mathrm{P}$ to its solution in $\mathrm{CH}_{2} \mathrm{Cl}_{2}$; the yellow colour of 4-nitrophenolate was restored by the addition of fluoride anion, as can be inferred from Fig. $24 .{ }^{135}$ Using UVVis spectroscopic analysis, they observed a significant decrease in intensity of the band at $432 \mathrm{~nm}$ upon the addition of C4P to tetrabutylammonium 4-nitrophenolate (Fig. 25), and the strongest absorbance was also observed upon the addition of $\mathrm{F}^{-}$followed by $\mathrm{Cl}^{-}$and phosphate ion (Table 7$).{ }^{135}$

\subsection{Calix[4]pyrroles as ion-pair receptors}

Receptors that can bind both anionic and cationic guests are particularly interesting because they may permit modification of their recognition properties by suitable assignment of the ion binding locations within properly preorganized frameworks. The C4P scaffold has emerged as an effective supramolecular receptor for ion pairs and has the ability to bind the cation as well as the anion simultaneously, with higher selectivity compared to simple ion receptors. ${ }^{\mathbf{1 0 1 , 1 3 6 - 1 4 4}}$ The enhancement in the recognition function of $\mathrm{C} 4 \mathrm{P}$-based ion-pair receptors is by 

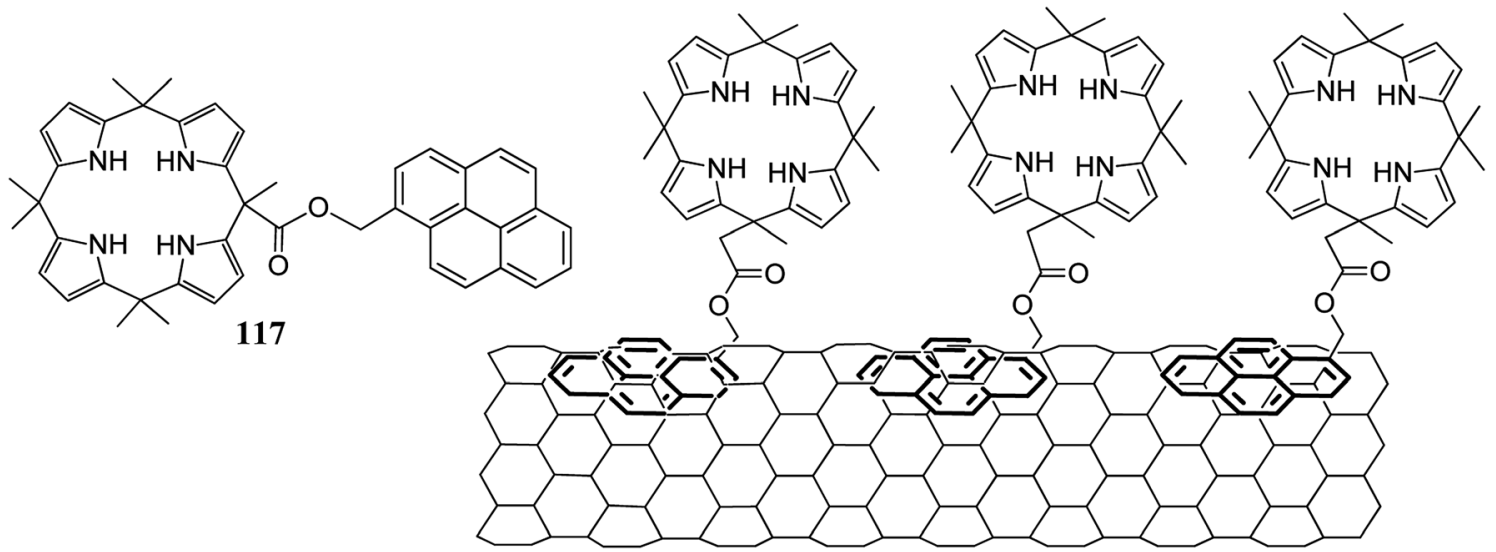

118

Fig. 23 Molecular structure of pyrene-functionalized C4P 117 and an illustration of C4P 117-decorated SWCNT 118.

virtue of both positive allosteric effects and electrostatic interactions in the ion pairs. These C4P-based ion-pair receptors are also competent to curtail the solvation effects of the counterions, which can otherwise have an undesirable effect on the interaction between the receptors and the targeted ions. ${ }^{\mathbf{1 4 0 - 1 4 2}}$ Here, we highlight some important C4P-based ion-pair receptors, and we will take into consideration ditopic ${ }^{145}$ as well as multitopic ion-pair receptors. ${ }^{146-148}$
In order to produce advanced ion-pair receptors, many research groups have functionalized the $\beta$ - and meso-carbon atoms of the C4P loop with various cation recognition sites. ${ }^{120}$ Researchers have linked crown ethers of varying sizes with the meso-carbon atoms of the C4P skeleton, as in compounds 90 and 91. ${ }^{28,96}$ When 123 is exposed to cations such as $\mathrm{Li}^{+}, \mathrm{K}^{+}$, and $\mathrm{Cs}^{+}$in acetonitrile, ion-pair complexation occurs. In sharp contrast to cations such as $\mathrm{Li}^{+}$and $\mathrm{K}^{+}$bound inside the crown

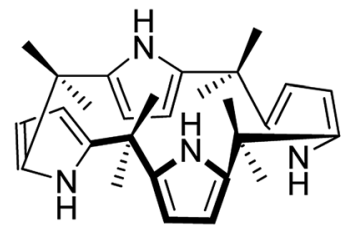

1,3-Alternate conformation

10

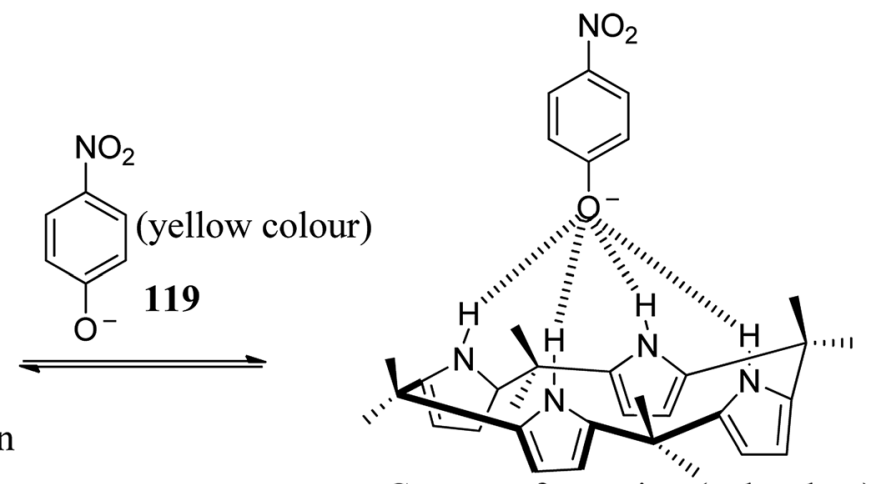

Cone conformation (colourless)

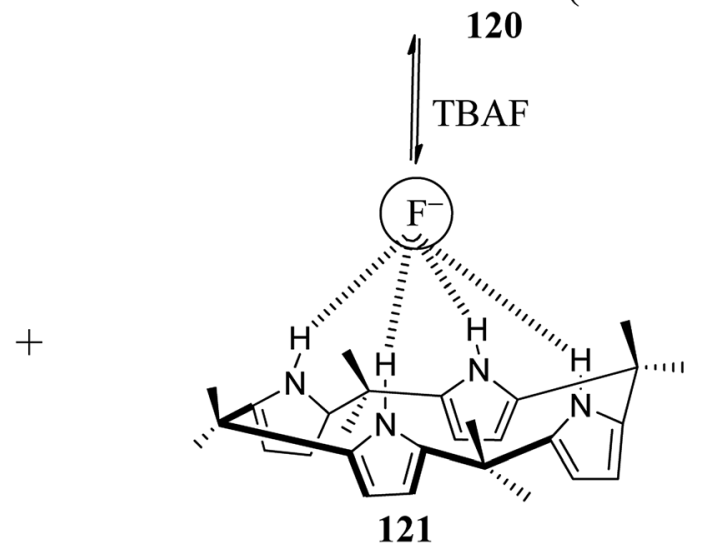

Fig. 24 C4P as an anion sensor for tetrabutylammonium-4-nitrophenolate.<smiles>O=[N+]([O-])c1ccc([O-])cc1</smiles>

(yellow colour)

119

- 24 c4 as an anion sensor for tetrabutylammonium-4-nitrophenolate. 


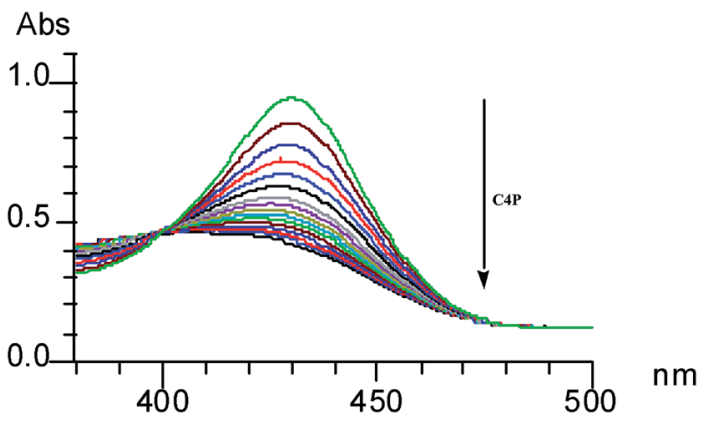

Fig. 25 Decreasing absorbance of the 4-nitrophenolate anion upon addition of $\mathrm{C} 4 \mathrm{P}$ in $\mathrm{CH}_{2} \mathrm{Cl}_{2}$ at $25^{\circ} \mathrm{C}$ (reproduced with permission from ref. 135. Copyright 1999 Royal Society of Chemistry).

Table 7 Relative absorbance values of 120 with equimolar concentrations of anions

\begin{tabular}{llllll}
\hline & $\mathrm{F}^{-}$ & $\mathrm{Cl}^{-}$ & $\mathrm{H}_{2} \mathrm{PO}_{4}{ }^{-}$ & $\mathrm{Br}^{-}$ & $\mathrm{HSO}_{4}{ }^{-}$ \\
\hline$\Delta A$ & 0.282 & 0.193 & 0.162 & 0.092 & 0.015 \\
Relative absorbance & 1.0 & 0.68 & 0.57 & 0.33 & 0.05
\end{tabular}

ether of 123, the cesium cation was found to be coordinated with the cone conformation of the C4P cavity (Fig. 26). Exposure of $\mathbf{1 2 3}$ to sodium, magnesium or calcium perchlorate salts leads to decomplexation of chloride anion, as can be inferred from Fig. $26{ }^{28}$

The multitopic ion-pair receptor 94 comprises one anion binding site and three cation recognition sites (Fig. 27). The 1,3alternate conformer of $\mathbf{9 4}$ has an inherent partiality for $\mathrm{K}^{+}$ comparative to $\mathrm{Cs}^{+}$. In the absence of the $\mathrm{K}^{+}$cation, the receptor 94 likely forms the complex with $\mathrm{Cs}^{+}$cation. Subsequently, it must be exposed to the $\mathrm{K}^{+}$cation in order to release the $\mathrm{Cs}^{+}$ cation, as can be inferred from Fig. 27. ${ }^{142,146}$

Recently, Ballester's group reported a neutral [2]rotaxanebased C4P system 127, which was found to be an effective heteroditopic receptor for tetraalkylammonium salts of anions $\left(\mathrm{Cl}^{-}, \mathrm{NO}_{3}{ }^{-}\right.$, and $\left.{ }^{-} \mathrm{OCN}\right)$ in chloroform solution (Fig. 28). ${ }^{149} \mathrm{From}$ ${ }^{1} \mathrm{H}-\mathrm{NMR}$ and ITC studies, they inferred the formation of thermodynamically as well as kinetically stable $1: 1$ ion-pair complexes for all the above mentioned anions, and they also reported selectivity for cyanate anion over chloride or nitrate ion in the case of their tetrabutylammonium (TBA) salts. In addition to this, they observed an almost three-fold increase in binding affinity in the case of the chloride ion-pair when they changed the cation from TBA to methyltrioctylammonium (MTOA). In 2012, the same group reported [2]pseudorotaxane 128, which displays ion-pair recognition (Fig. 28). ${ }^{150}$ They observed that on adding more than 1 equiv. of the TBA salt of an anion $\left(\mathrm{Cl}^{-}, \mathrm{NO}_{3}{ }^{-}\right.$, and $\left.{ }^{-} \mathrm{OCN}\right)$ to 127 and 128 , the $1: 1$ stoichiometric complexes gradually disassemble to $2: 1$ stoichiometric complexes (Fig. 29). ${ }^{149}$

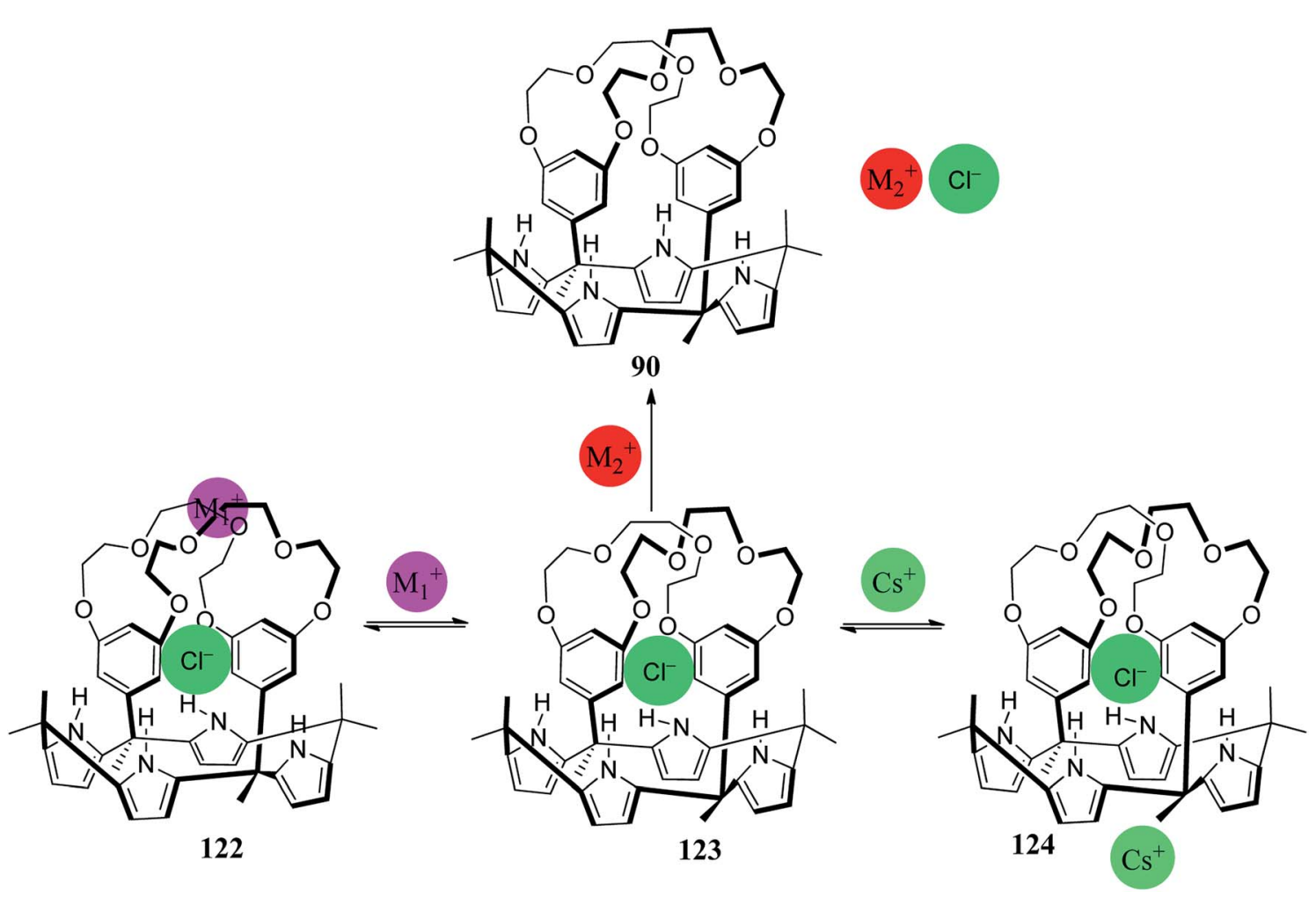

Fig. 26 Complexation behaviour observed for $123 \mathrm{TBA}$ salt upon introduction to perchlorate salts of the metal cation in $\mathrm{CH}_{3} \mathrm{CN}\left(\mathrm{M}_{1}{ }^{+}=\mathrm{Li}^{+}\right.$and $\mathrm{K}^{+} ; \mathrm{M}_{2}^{+}=\mathrm{Ca}^{2+}, \mathrm{Mg}^{2+}$, and $\mathrm{Na}^{+} ; \mathrm{M}_{2}^{+} \mathrm{Cl}^{-}=\mathrm{CaCl}_{2}, \mathrm{MgCl}_{2}$, and $\mathrm{NaCl}$ ). 


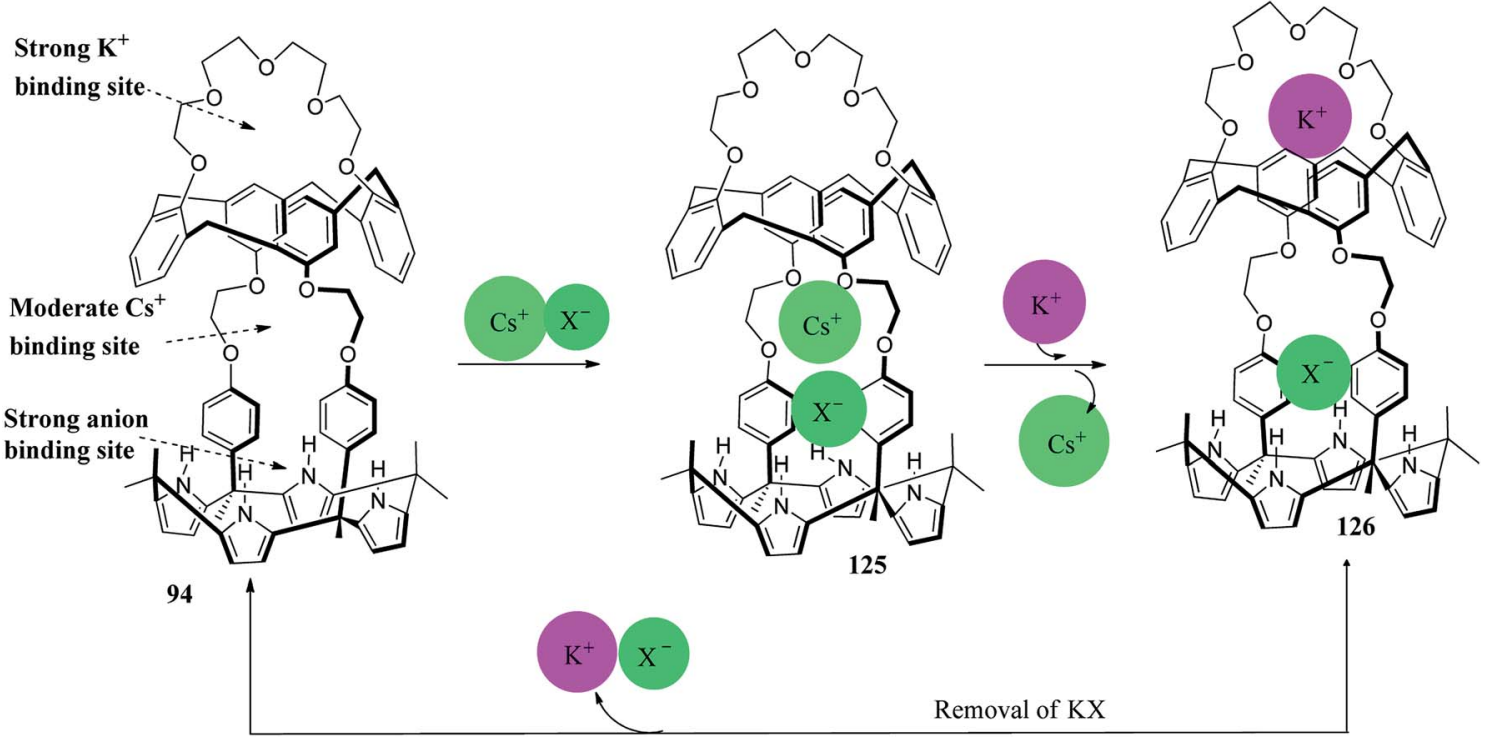

Fig. 27 Schematic view of ion-pair receptor 94.

In addition, they reported bis-C4P macrocycle $\mathbf{1 3 0}$ and its pair-wise anion binding with tetraalkylammonium salts. This pair-wise binding signifies switching between negative cooperativity and no cooperativity. ${ }^{151}$ The use of TBA $\cdot \mathrm{Cl}$ and TBA $\cdot$ OCN afforded 2:1 ion-pair receptor complexes. These complexes possess close-contact or cascade-like binding geometries of the incorporated ion-triplet, which does not display allosteric binding cooperativity (Fig. 30). In sharp contrast, MTOA.Cl binding displays large negative cooperativity in terms of the receptor-separated binding geometries of two bound ion-pairs (Fig. 30). ${ }^{151}$

Recently, Yeon et al. constructed a hybrid chromogenic calix [4]arene-calix[4]pyrrole ion-pair receptor, 131 (Fig. 31). Using solution-phase spectroscopic analysis, it was revealed that receptor $\mathbf{1 3 1}$ is capable of binding cesium ion pairs only. It was found that this chromogenic receptor displays AND logic gate behaviour and displays a colorimetric response to cesium ion pairs under solid-liquid and liquid-liquid extraction conditions (Fig. 31). ${ }^{152}$

Lee's group also observed that the fluorescence intensity of receptor 76 was enhanced by the addition of $\mathrm{Na}^{+}$ion and decreased by the addition of $\mathrm{Cl}^{-}$ion. The sodium cations are believed to bind to the carbonyl oxygen atom of coumarin, leading to inhibition or turning off the intrinsic photoinduced electron transfer (PET) quenching process. On the other hand, anions such as $\mathrm{Cl}^{-}$are known to bind inside the $\mathrm{C} 4 \mathrm{P}$ core and
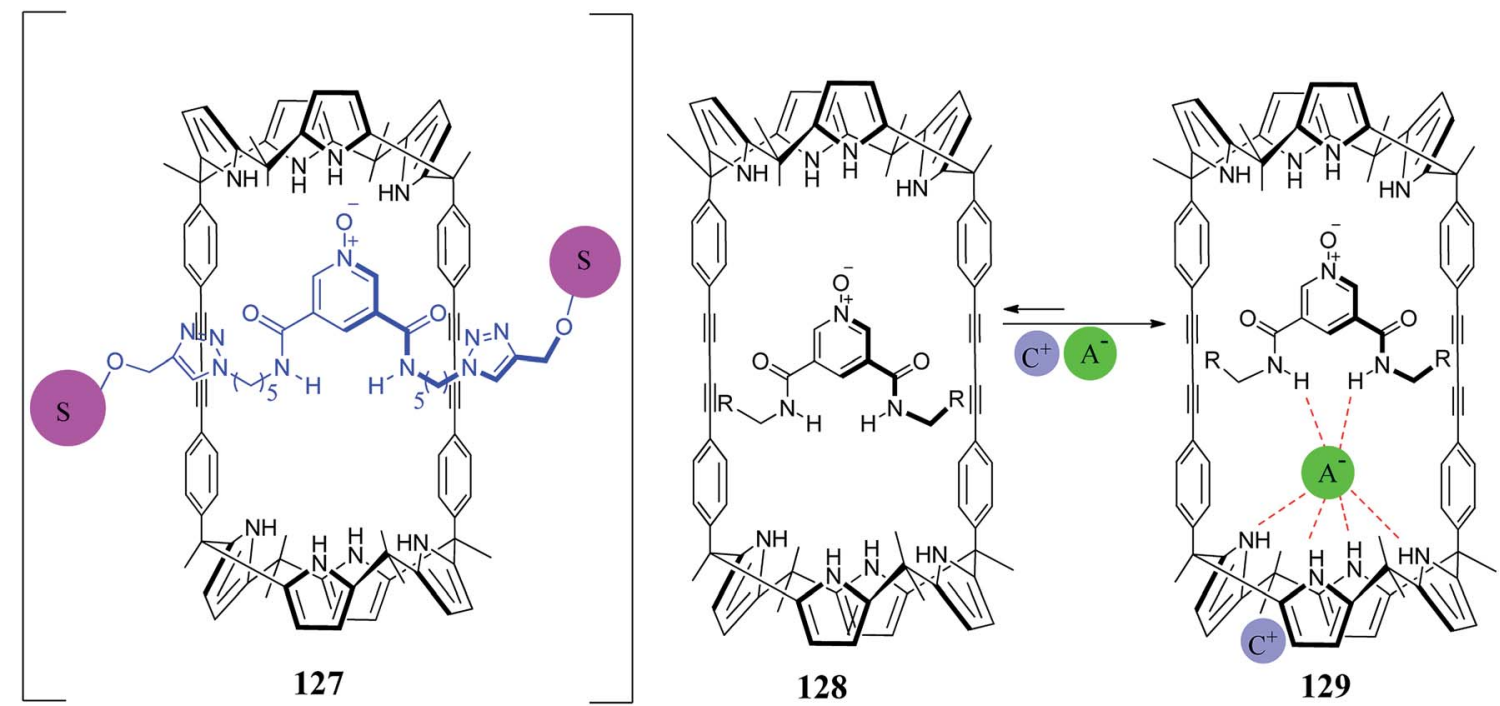

Fig. 28 Molecular structure of [2]rotaxane 127 and ion-pair recognition of [2]pseudorotaxane 128. 

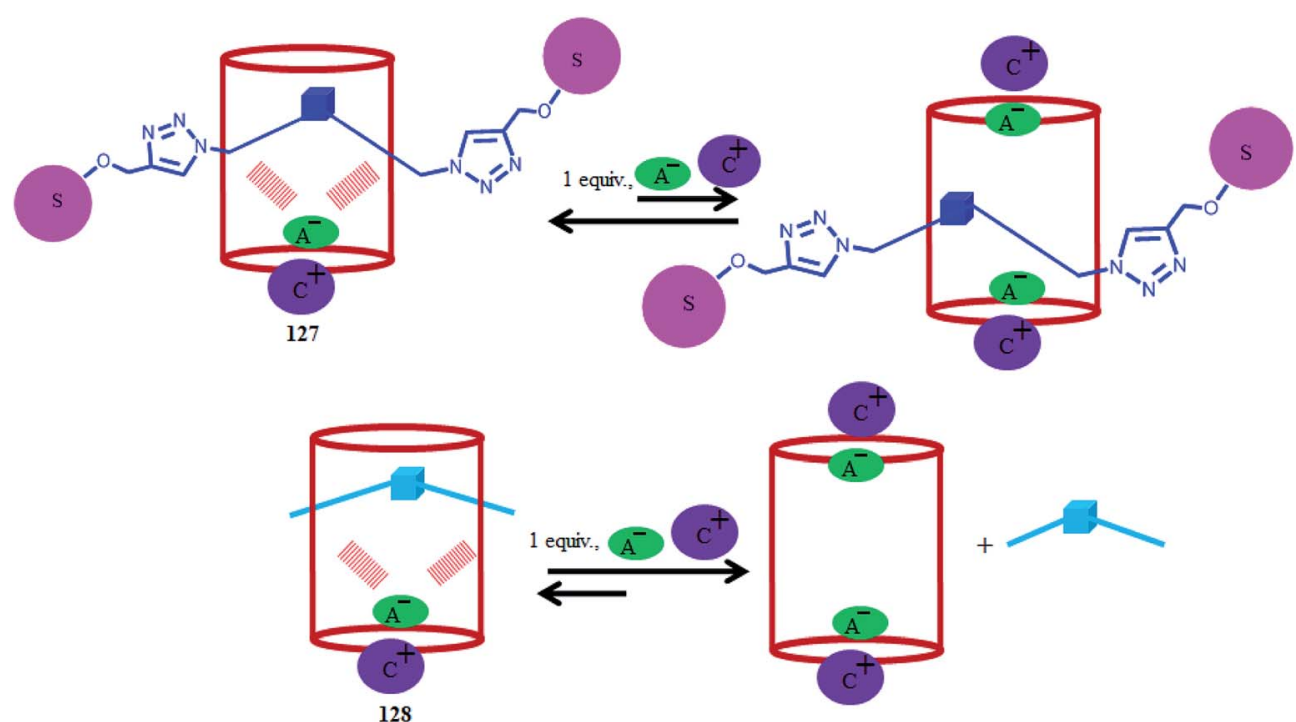

Fig. 29 Cartoon representation of the probable equilibria involved in the disassembly of $1: 1$ ion-paired complexes of [2]rotaxane 127 and [2] pseudorotaxane 128

help quench the fluorescence by activating a different PET mode (Fig. 32 ) ${ }^{84}$ Thus, the receptor $\mathbf{7 6}$ acts as a supramolecular logic device.

\subsection{Calix[4]pyrroles in electron transfer processes}

For many biological energy conversions, reversible electron transfer (ET) reactions are an indispensable attribute. These electron transfer reactions are operated by cofactors and ionic species; both forward and backward electron transfer are supported. In TTF-C4P, the electron-rich TTF arms are responsible for various charge and electron transfer processes. Park et al. studied S-Pr-TTF-C4P 31 in concurrence with an electrondeficient bis-imidazolium quinone dication $\left(\mathrm{BIQ}^{2+}\right)$ acceptor, 136. ${ }^{153}$ Electrostatic considerations support the better electrondonor nature of the anion-bound cone conformer 31. Hence, it favours electron transfer; the "On-ET state" is achieved on binding with the electron-deficient $\mathrm{BIQ}^{2+}$ guest, leading to an overall $2: 1$ receptor/substrate ratio $\left([31]_{2}{ }^{\cdot+} \cdot \mathrm{BIQ}^{\cdot+} \cdot 2 \mathrm{Cl}^{-}\right)$, as can be observed from Fig. 33. On the other hand, $\mathrm{TEA}^{+}$cation can also bind in the cone conformer by dislocating the $\mathrm{BIQ}^{2+}$ guest. Thus, it hinders the electron transfer and creates the "Off-ET

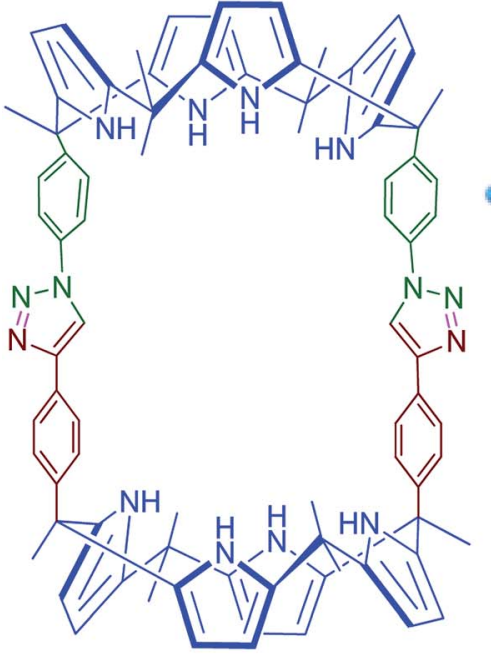

130

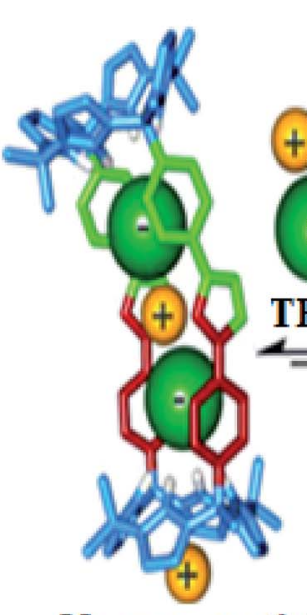

No-cooperativity

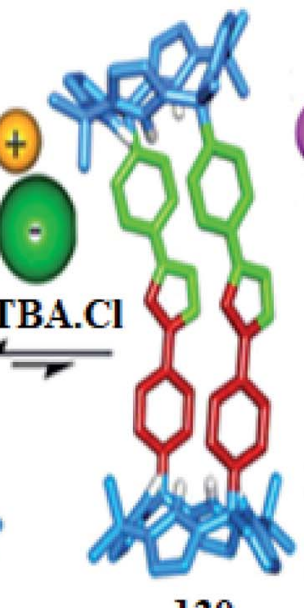

130

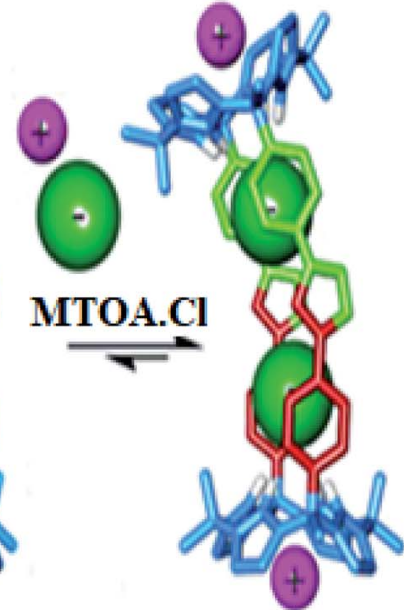

Negative-cooperativity

Fig. 30 Molecular structure of bis-C4P macrocycle 130 and schematic of absent and negative cooperativity after binding ion-pair dimers (reproduced with permission from ref. 151. Copyright 2018 American Chemical Society). 


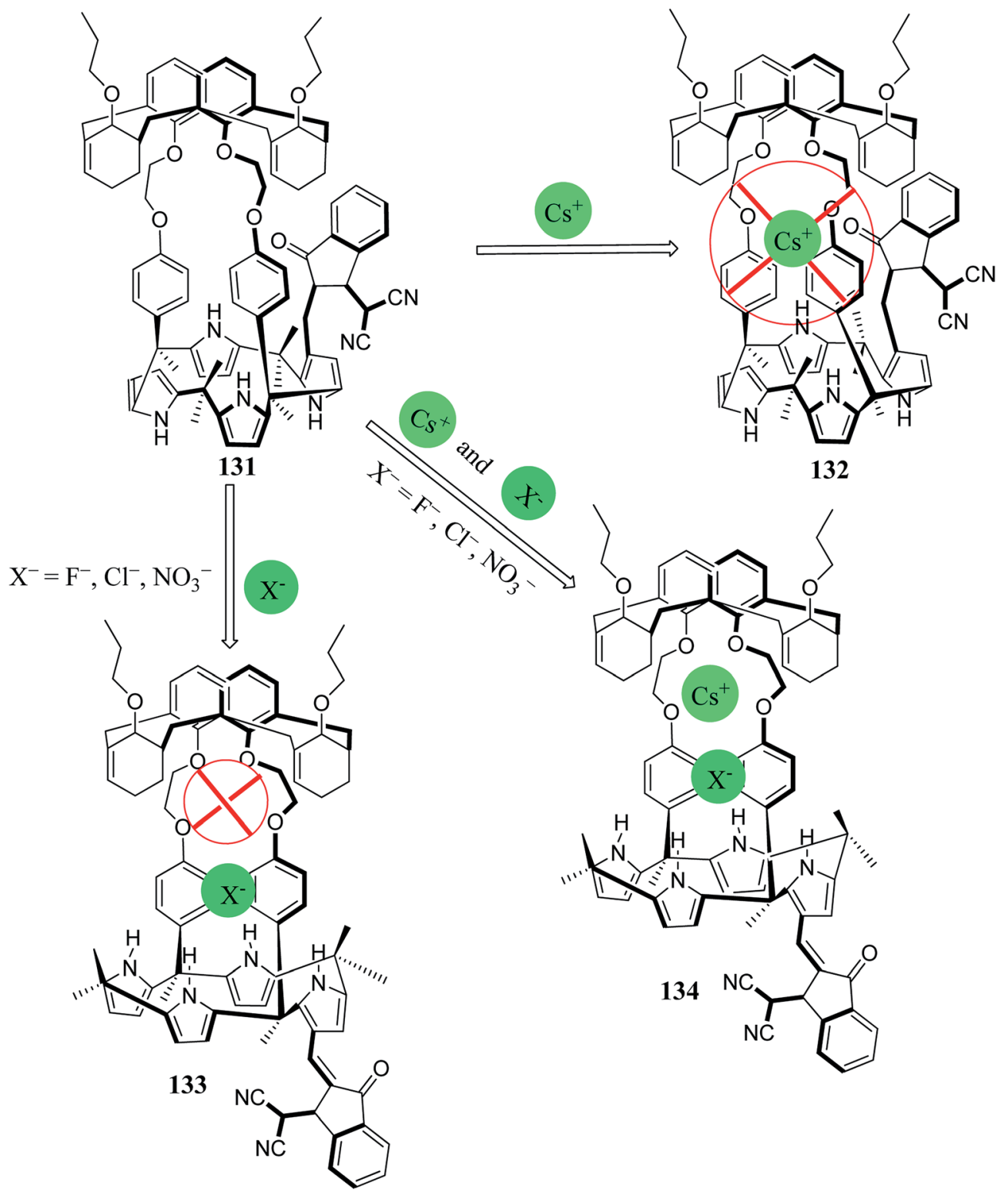

Fig. 31 AND logic gate behavior exhibited by the ion pair receptor 131 after exposure to different cesium salts in $10 \% C D_{3} O D-C D C l_{3}$.

state," as can be observed from inspection of Fig. 33. Thus, by employing different ionic inputs, switching between "On-ET" and "Off-ET" states could be accomplished perfectly. ${ }^{153}$

On the other hand, Sessler and his teammates described another electron transfer system involving TTF-C4Ps and the electron acceptor $\mathrm{Li}^{+} @ \mathrm{C}_{60}$, which is significantly easier to reduce. ${ }^{154}$ The presence of a suitable anion source (TBACl) leads to a ground-state electron transfer "On-ET state" of the resulting 1:1 receptor/substrate complex, $[31]^{\cdot+} \cdot\left[\mathrm{Li}^{+} @ \mathrm{C}_{60}\right]^{\cdot-} \cdot \mathrm{Cl}$. On adding a small competitive cation $\left(\mathrm{TEA}^{+}\right)$to the ET complex, the ET process is switched off to the "Off-ET state," as can be seen from Fig. 34.

\subsection{Calix[4]pyrroles as molecular nanocontainers for ion transport}

In the last two decades, C4Ps have been used as molecular nanocontainers for the removal of both anions and ion-pairs. In 2008, Tong et al. demonstrated the transmembrane transport studies of $\mathrm{C} 4 \mathrm{P}$ and revealed that this nanocontainer acts as a mediator for the transport of $\mathrm{CsCl}$ across the lipophilic membranes with greater selectivity and competence compared to other alkaline salts (Fig. 35). ${ }^{16,58,155}$

In 2011, Kim et al. used receptor 94 for the selective removal of $\mathrm{CsNO}_{3}$ from aqueous phase followed by complexation in the organic phase (nitrobenzene), which upon exposure to $\mathrm{KClO}_{4}$ releases $\mathrm{Cs}^{+}$ion (Fig. 36). Finally, regeneration of receptor 94 


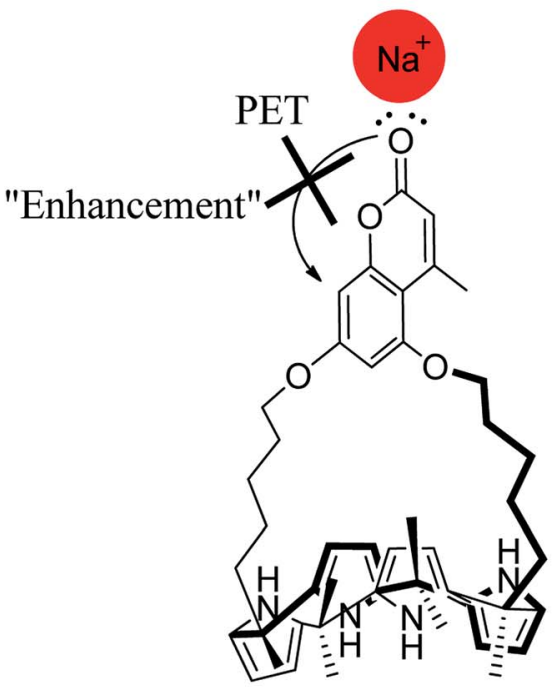

Fluorescence change Low $\rightarrow$ High 76

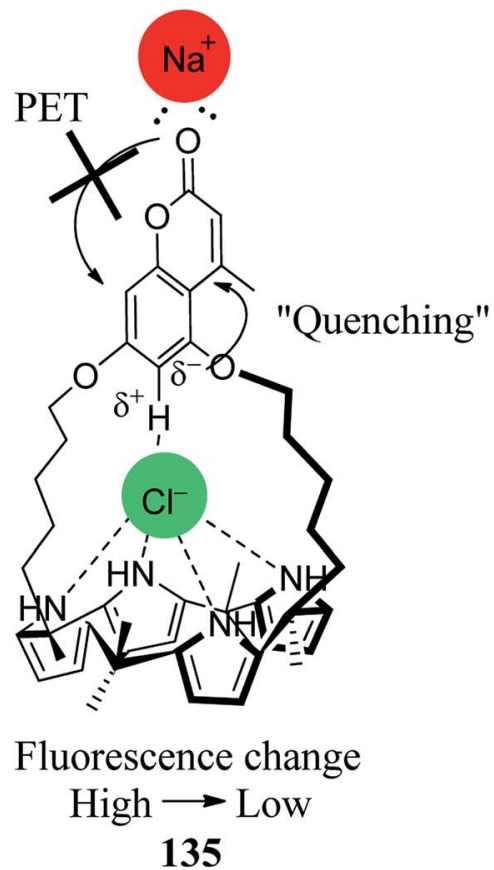

Fig. 32 Diagrammatic depiction of the anticipated interactions between 76 with sodium cation and a chloride anion.

occurs in the organic phase after the nitrobenzene layer comprising the potassium complex comes in contact with $\mathrm{H}_{2} \mathrm{O}$ and $\mathrm{CHCl}_{3}$ (Fig. 36). ${ }^{142}$ These two-phase extraction studies, therefore, highlight the importance of strapped C4Ps. ${ }^{146}$

Fluoride is a stabilizer in water and oral hygiene products; ${ }^{156}$ it can be harmful to health at high levels and can lead to fluorosis, which affects both teeth and bones. ${ }^{157}$ Fluoride complexation in water has become a taxing problem due to its small size, hard and basic nature and higher hydration energy. Deprotonation of anion receptors by fluoride in organic environments ${ }^{158-162}$ is also a challenging process for fluoride complexation. Thus, there is a need to develop novel fluoride receptors which can overcome the abovementioned challenges. To this end, in 2016, Gale and his teammates reported the electrogenic mechanism of selective fluoride anion transport across lipid bilayers by virtue of strapped C4P 99, as can be observed from Fig. 37. ${ }^{163}$ Because anion transporters such as strapped C4P 99 can bind and assist the flip-flop of fatty acids across lipid bilayer membranes, ${ }^{164}$ the interaction of 99 has

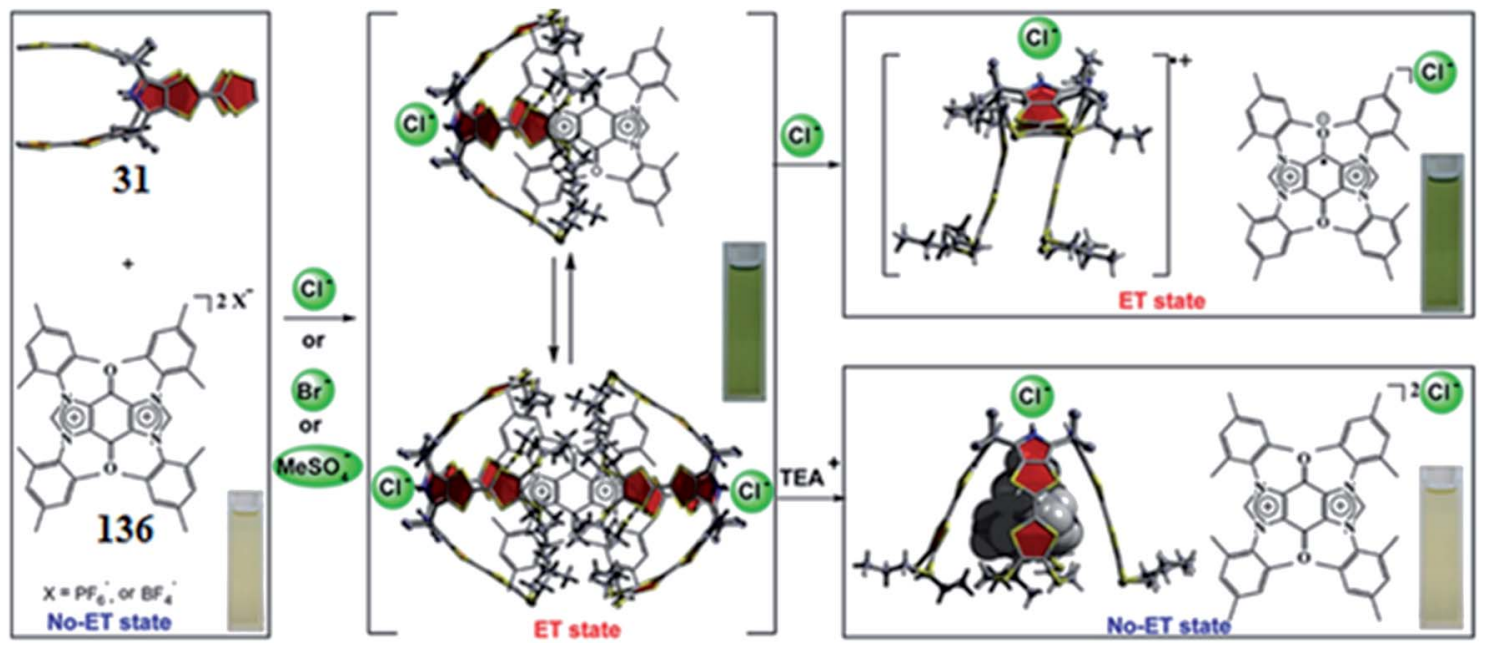

Fig. 33 Ion-intervened electron-transfer event between TTF-C4P 31 and $\mathrm{BIQ}^{2+}$ acceptor 136 (reproduced and adapted with permission from ref. 153. Copyright 2010 Science). 

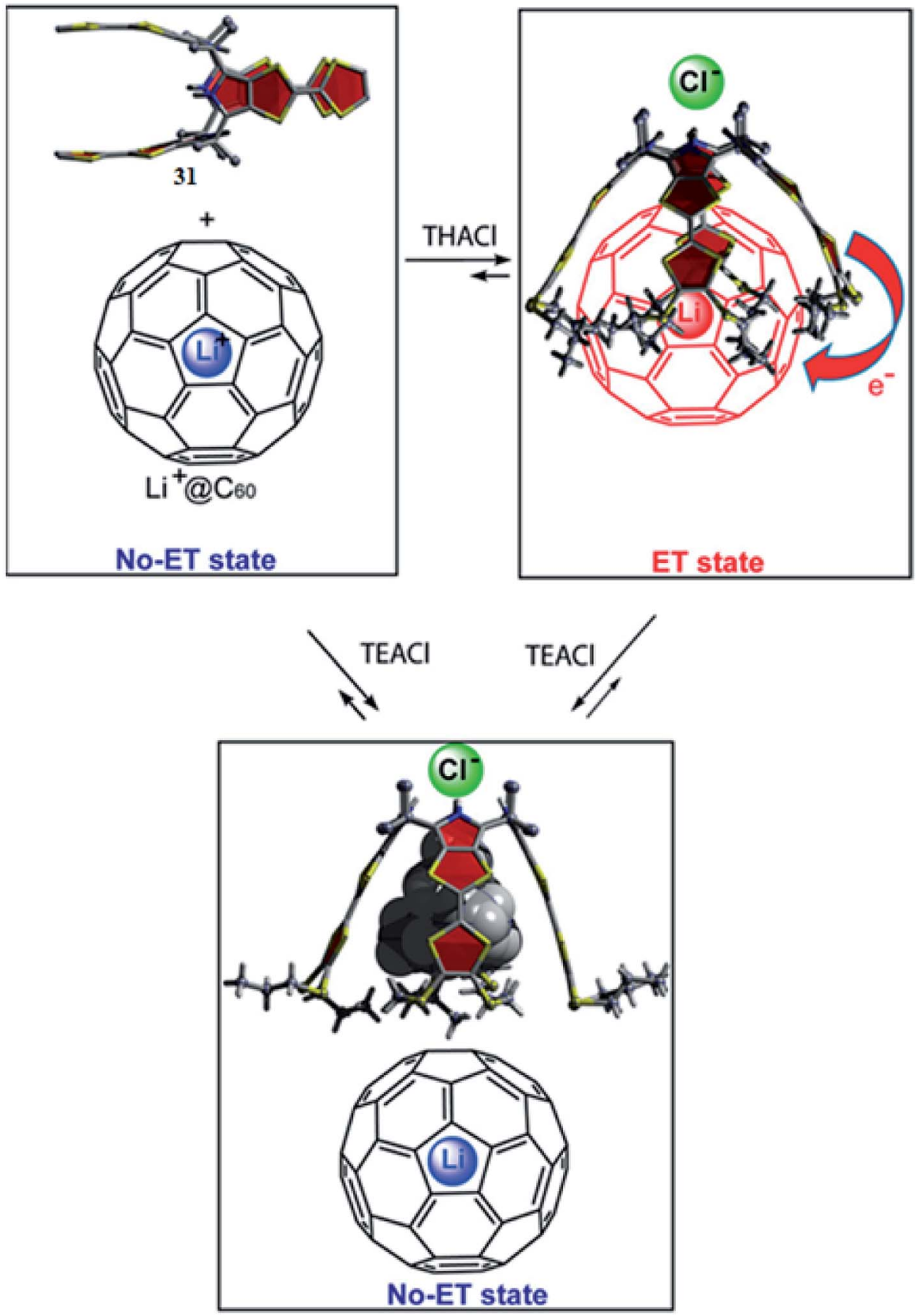

Fig. 34 Ion-intervened electron-transfer route relating TTF-C4P 31 and $\mathrm{Li}^{+} \mathrm{aC}_{60}$ (reproduced with permission from ref. 56. Copyright 2018 American Chemical Society).

been studied with $\mathrm{CH}_{3} \mathrm{COO}^{-}$in solution and fatty acids in lipid bilayer membranes. ${ }^{165}$

\subsection{Calix [4]pyrroles as drug delivery and anticancer agents}

Toxic side effects of drugs pose a serious threat to human life. Therefore, in order to safely achieve the desired therapeutic effect of a pharmaceutical agent (drug) in a particular body tissue without causing many side effects, it is necessary to develop approaches and create systems which enable pharmaceutical agents to reach the target site in the body and display a desired therapeutic effect only at that target site. These systems are known as drug delivery systems. In fact, recent efforts in the domain of drug delivery are focusing on the development of targeted drug delivery, in which the drug becomes active only in the target area of the body. Based on the accomplishments of supramolecular chemistry, various novel drug-delivery approaches have also come into existence in recent years. ${ }^{166-169}$ C4Ps, by virtue of their anion binding ability along with their ion-pair and neutral molecule receptor 

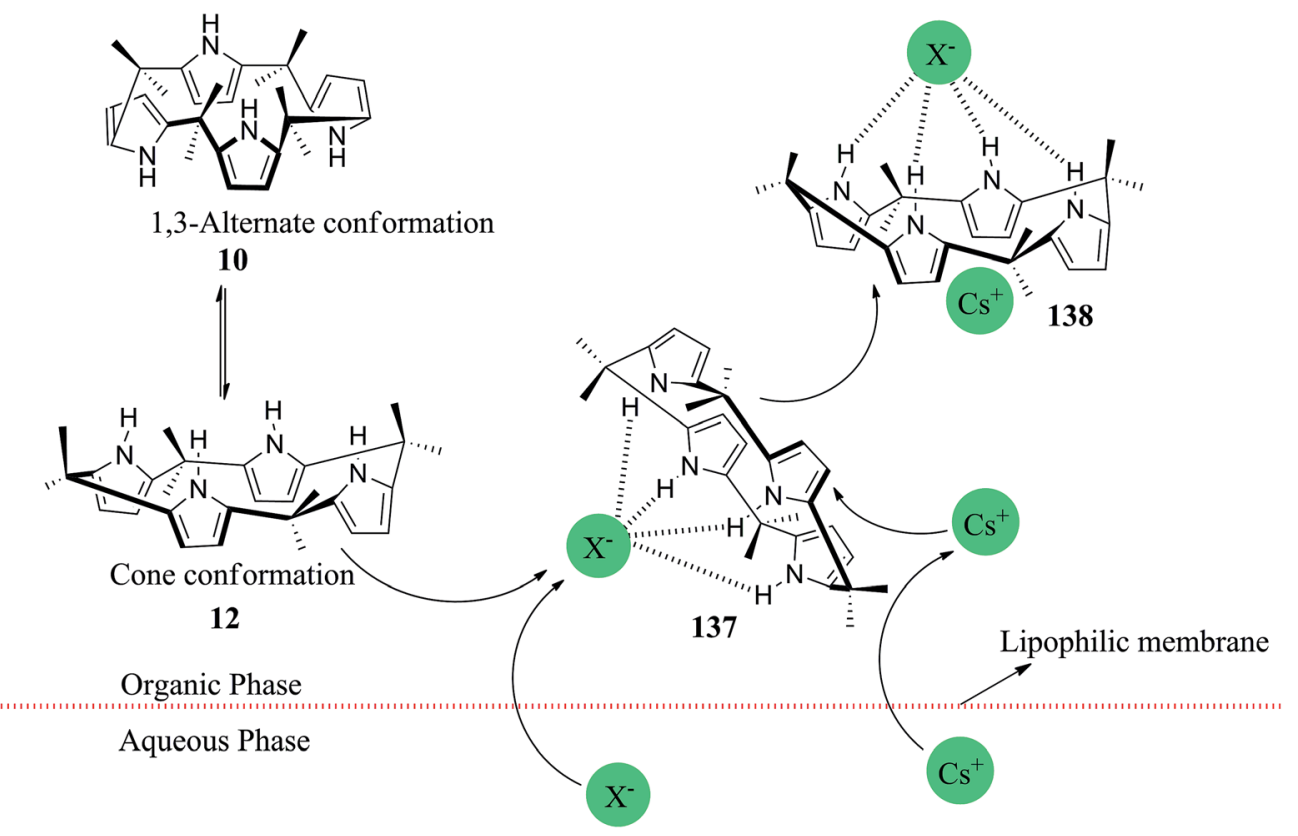

Fig. 35 Schematic illustration showing cesium halide salt extraction across a lipophilic membrane.

nature, have gained significant attention in the domain of drug delivery. Although C4Ps are not toxic themselves, the conjugates they form with various pharmaceutical agents display cytotoxicity to cell lines. Thus, these have been fruitfully used in the delivery of active pharmaceutical agents; for example, Cafeo et al. reported in 2013 that a C4P-trans-platinum(II) conjugate (trans-Pt 40) could be used as a prodrug, thereby highlighting the role of C4Ps in drug delivery. ${ }^{58}$ They used adenosine monophosphate (AMP) as a typical compound to assess the potential of the targeted delivery of metal to deoxyribose nucleic acid (DNA) nucleobases, as can be observed in Fig. 38. In vitro studies of trans-Pt $\mathbf{4 0}$ on diverse cancer cell lines signify cytotoxic activity that is categorically obtained from the co-occurrence of both the trans-Pt(II) portion and the $\mathrm{C} 4 \mathrm{P}$ unit. It exhibits good antiproliferative activity compared to trans-[ $\left.\mathrm{PtCl}_{2}\left(\mathrm{NH}_{3}\right)_{2}\right]$, in which $\mathrm{Pt}(\mathrm{II})$ is not bound to the C4P core. ${ }^{58}$

Lappano et al. reported that C4P (1) acts as a G-protein coupled estrogen receptor 1 (GPER1) antagonist in both breast tumour cells and cancer-associated fibroblasts (CAFs) obtained from breast cancer patients. C4P (1) exhibits inhibitory action on GPER-activated signals. Upon exposure to estrogen, it becomes highly selective for GPER without interfering with estrogen receptor-dependent responses. ${ }^{170-174}$

Sessler's group also reported that two pyridine diamidestrapped C4Ps, 142 and 143, can induce apoptosis through facilitation of chloride anion transport into cells (Fig. 39). ${ }^{175}$ Quite recently, Park et al. reported that the ion transporter octafluorocalix[4]pyrrole 16 (Fig. 4) also induces apoptosis by increasing the sodium and chloride concentrations of cells. ${ }^{176}$ In addition to inducing apoptosis, it has also been observed that ion transporter octafluorocalix[4]pyrrole 16 inhibits autophagy. This suppression of autophagy is due to its ability to interrupt lysosome function. Pyridine diamide-strapped C4P 143 has been observed to display enhanced cell death without interfering with autophagy. ${ }^{176}$

On the other hand, Geretto et al. recently reported a novel meso-( $p$-acetamidophenyl)-C4P, 144 (Fig. 39), which acts as a potential anticancer agent and forms genotoxic adducts with DNA. ${ }^{177}$ Pharmacokinetic studies revealed that $\mathbf{1 4 4}$ is a potential drug that has the ability to cross the blood-brain-barrier and simultaneously kill both primary and metastatic brain cancer cells.

\subsection{Calix[4]pyrroles as catalysts}

Scientists have developed novel artificial catalysts which are of considerable physical and biological importance. These catalysts mimic the action of enzymes, which are natural catalysts. bis-C4P capsule 46 (Scheme 8) acts as an artificial catalyst (mimics the action of an enzyme) and constrains two oxoanions in close proximity, thereby acting as a structural model for understanding natural oxo-anion recognition processes. ${ }^{18,179}$ In 2007, García et al. studied the effects of C4P on the catalytic activity of cuprous chloride $(\mathrm{CuCl})$ in the aziridination of chloramine-T with styrene; they finally concluded that C4P acts as a promoter for this reaction (Scheme 14). ${ }^{180}$ This finding provides a new approach to reaction enhancement, particularly when the anion receptor-like C4P activates an 


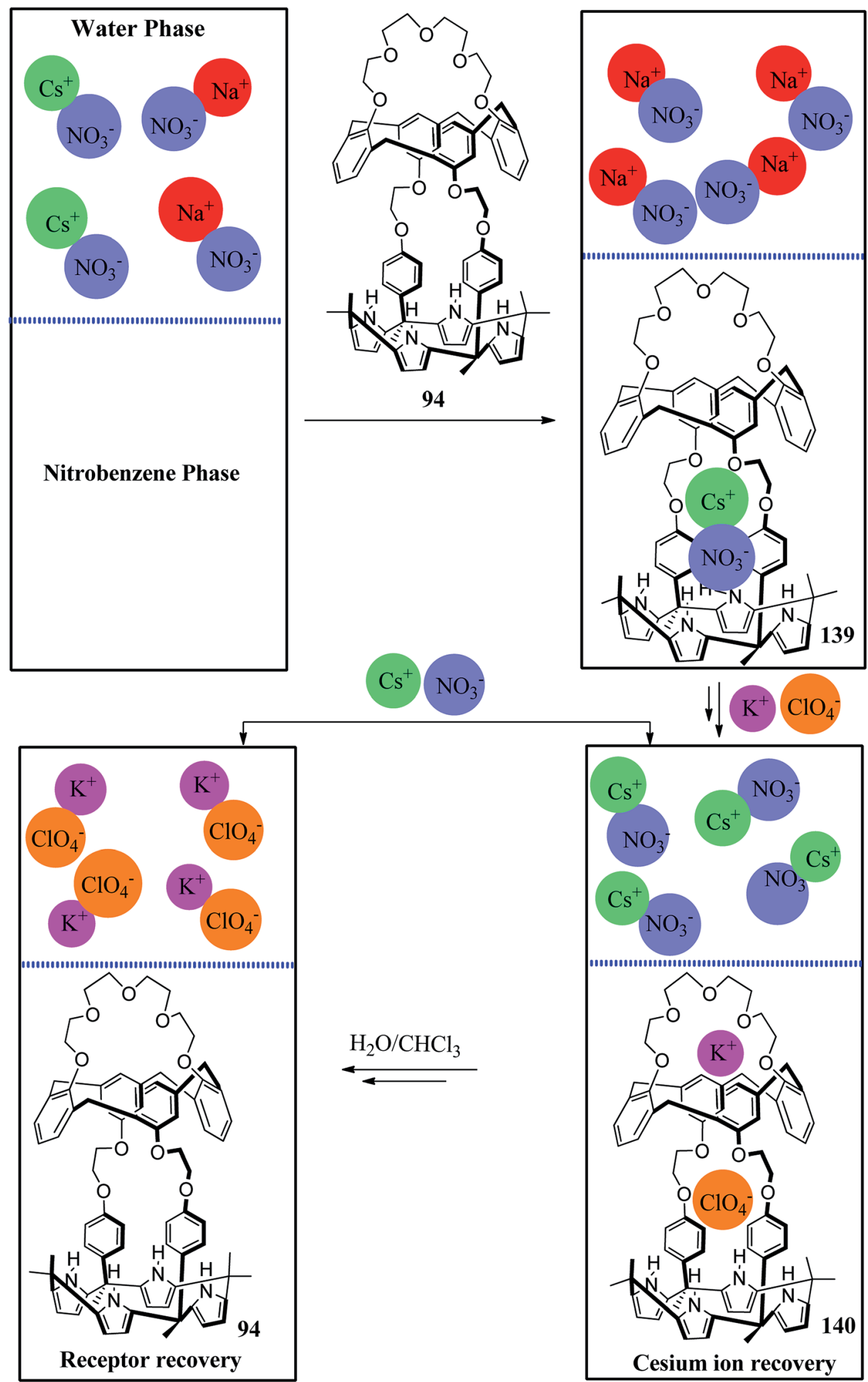

Fig. 36 Diagrammatic depiction of a two-phase $\mathrm{CsNO}_{3}$ removal and recovery process using ion-pair receptor 94 . 


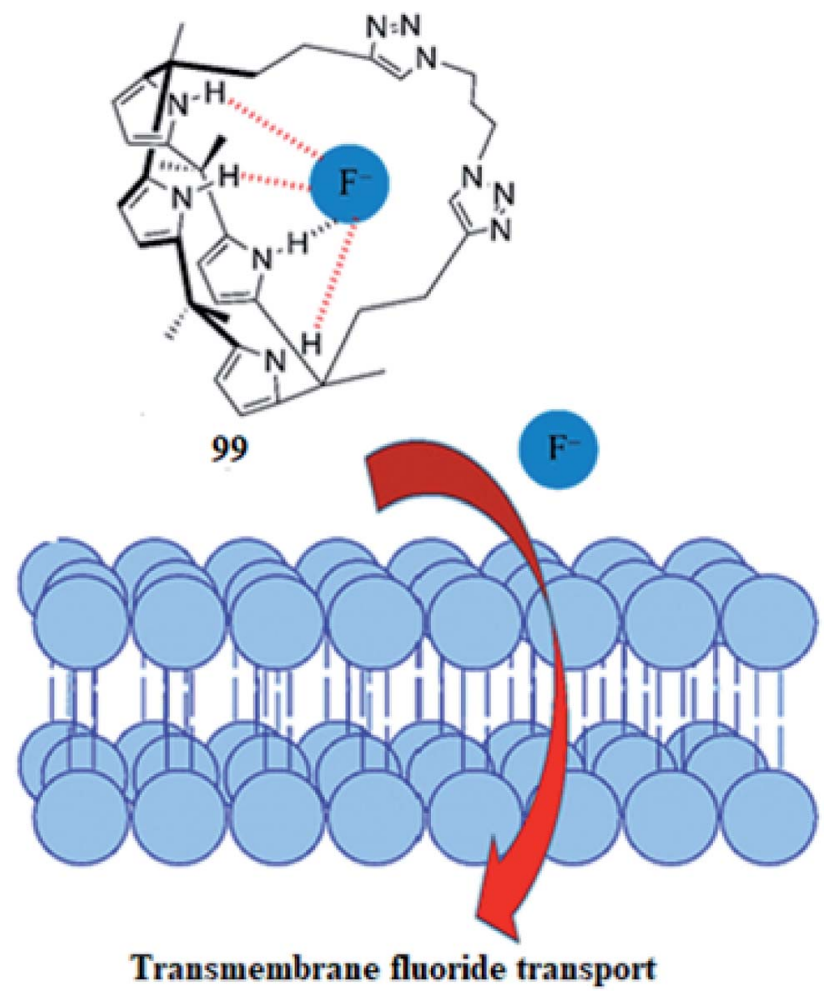

Fig. 37 Fluoride transport across biomembranes by virtue of strapped C4P 99.

incipient anion cleavage event. It was found that the presence of C4P has no effect when CuI is employed as a catalyst, showing the selectivity of $\mathrm{CuCl}$ towards the $\mathrm{C} 4 \mathrm{P}$. The yield was even lower in the case of the $\mathrm{CuCl}_{2}$-catalyzed reaction, displaying the

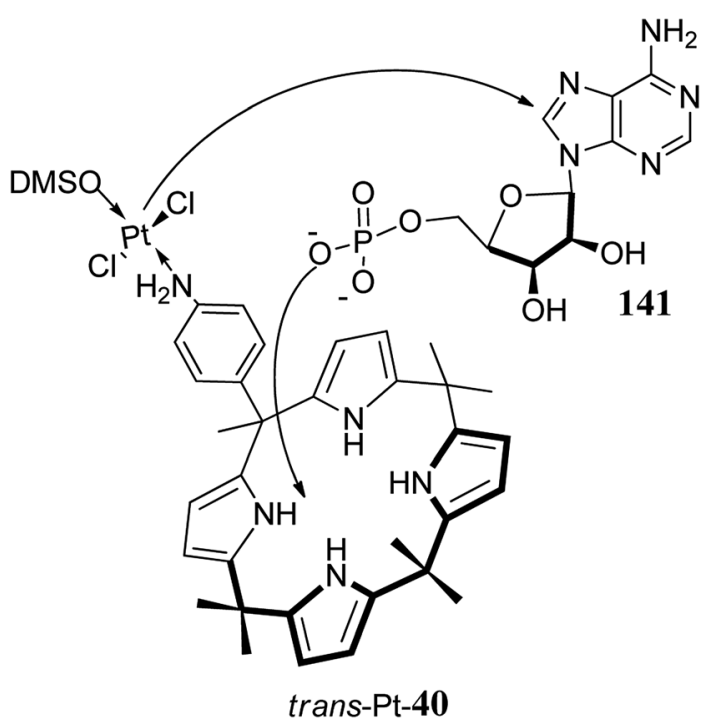

Fig. 38 Depiction of transfer of Pt metal from the C4P-trans-platinum(I) conjugate to DNA via phosphate anion-binding. selective nature of the reaction. In fact, the enhancement effect provided by $\mathrm{C} 4 \mathrm{P}$ was found to be independent of the presence of trace quantities of water. ${ }^{181}$ Thus, the proper and judicious selection of reaction chemistry along with anion receptors such as C4P is likely to open a new door for synthetic organic chemistry.

Chemical transformations of $\mathrm{CO}_{2}$ into beneficial compounds has received much attention because $\mathrm{CO}_{2}$ is considered to be a vital raw material in organic synthesis. ${ }^{182,183}$ Recently, Maeda and teammates reported that C4P 1 in association with tetrabutylammonium iodide (TBAI) catalyzes the transformation of epoxides and $\mathrm{CO}_{2}$ into cyclic carbonates (Scheme 15). ${ }^{184}$ Thus, C4P 1 acts as a robust and dynamic macrocyclic organocatalyst. It has been observed from DFT studies that C4P 1 organocatalyst stabilizes anionic species produced during catalysis only in the 1,3-alternate conformation. The key transition state of epoxide ring-opening involves activation of the epoxide by means of the pyrrolic NH of C4P $\mathbf{1}$ and tetrabutylammonium (TBA) cation-assisted hydrogen bonding. On the opposite side of $\mathrm{C} 4 \mathrm{P} 1$, another $\mathrm{NH}$ group directs $\mathrm{I}^{-}$anion. Being placed away from the TBA cation, the $\mathrm{I}^{-}$anion attacks the epoxide from the backside. ${ }^{184}$

On the other hand, in the same year, Sakthivel and coworkers reported the synthesis of rhodium calix[4]pyrrole 152 (Rh-C4P 152) and its catalytic applications in nitrobenzene reduction (Scheme 16). ${ }^{185}$ They grafted Rh-C4P 152 on the surface of a diamino-functionalized SBA-15 molecular sieve material, which eventually showed the complete reduction of nitrobenzene to aniline as a final product. It was observed that the catalytic activity of macromolecule Rh-C4P 152 was enhanced considerably and also remained intact even after numerous catalytic runs. ${ }^{185}$

\subsection{Use of calix[4]pyrroles in the advancement of polymer chemistry}

C4Ps by means of anion complexation have been employed to increase the ionic conductivity of solid polymer electrolytes such as $\mathrm{C} 4 \mathrm{P} / \mathrm{LiCl} / \mathrm{PVC}(\mathrm{PVC}=$ polyvinyl chloride) with great ionic mobility. Anion complexations were found between anions and C4Ps dissolved in PVC. The resulting systems have found versatile applications. ${ }^{186} \mathrm{Jain}$ et al. developed two novel azo-C4P amberlite XAD-2 polymeric chelating resins that were found to be important in the preconcentration and sequential removal of $\mathrm{Zn}(\mathrm{II}), \mathrm{Cu}(\mathrm{II})$ and $\mathrm{Cd}(\mathrm{II})$ in natural waters. ${ }^{187}$ Other C4P-based novel chelating resins, used for the preferential removal of fluoride anions over other halides, were synthesized by Trochimczuk and teammates. ${ }^{188,189}$ On the other hand, Trochimczuk and teammates also synthesized Langmuir-type isotherms for hybrid calixpyrroles, which were used as sorbents for noble cations such as $\operatorname{Ag}(\mathrm{I}), \operatorname{Pt}(\mathrm{IV}), \operatorname{Pd}(\mathrm{II})$, and $\operatorname{Au}(\mathrm{III}) \cdot{ }^{189,190}$ On another occasion, Aydogan et al. produced copolymers containing 


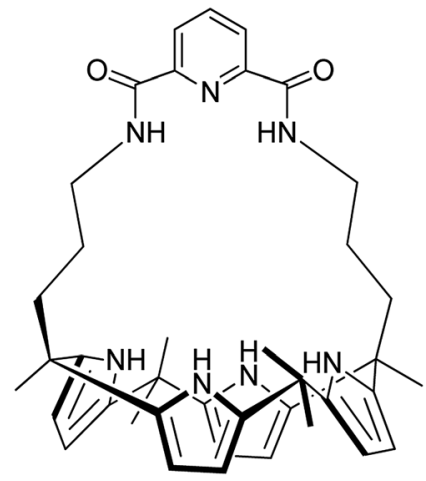

142

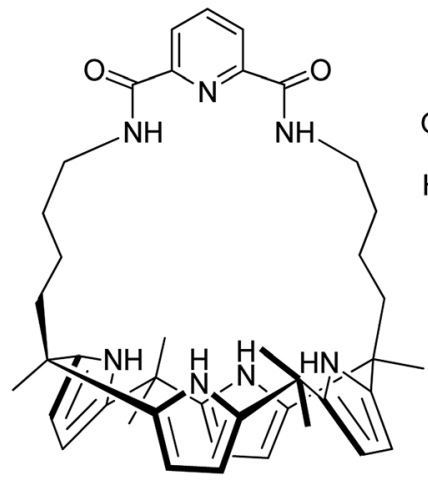

143



144

Fig. 39 Molecular structures of pyridine diamide-strapped C4Ps that induce apoptosis and meso-( $p$-acetamidophenyl)-C4P, which acts as a potential anticancer agent.
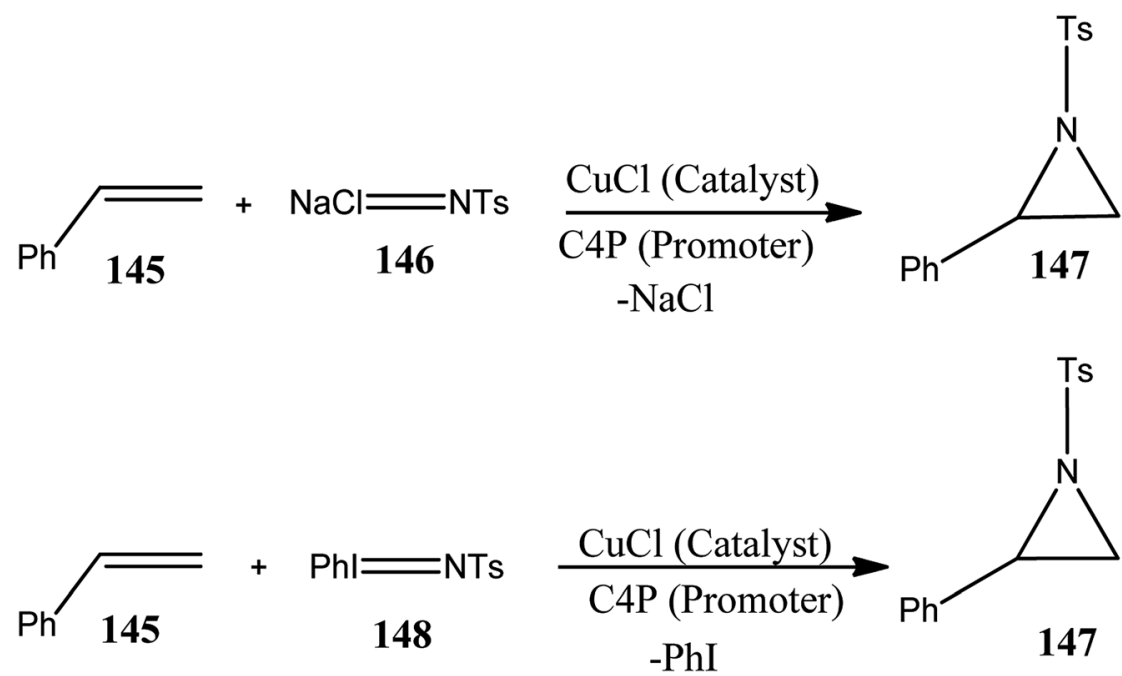

Scheme 14 Synthesis of aziridine products.

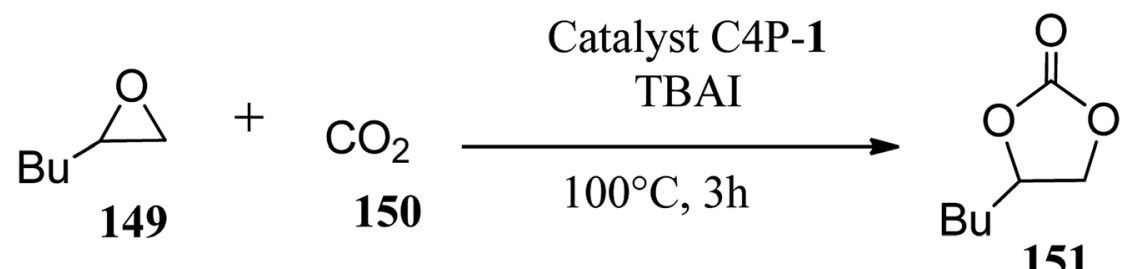

Scheme 15 Preparation of cyclic carbonates using macrocyclic C4P (1) as an organocatalyst.

C4Ps and showed that they can extract certain halide anion salts. ${ }^{191,192}$

The 1,3-alternate conformers of TTF-C4Ps 29, 31, and 33 can bind two nitroaromatics; this has led to the discovery of stabilizing chemoresponsive supramolecular polymeric materials by means of heterocomplementary donor-acceptor interactions. For this purpose, Sessler's group chose bis(dinitrophenyl) meso-substituted C4Ps which are electron- 

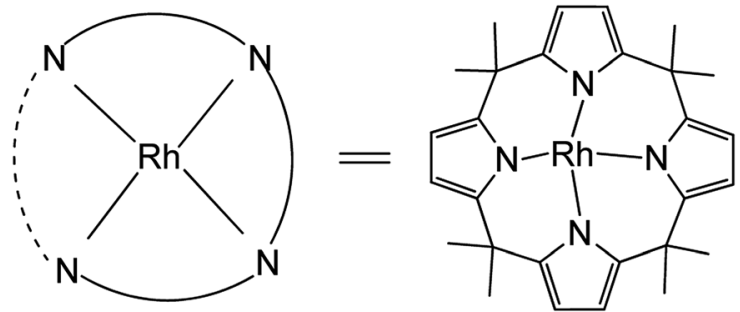

$\mathrm{Rh}-\mathrm{C} 4 \mathrm{P}$

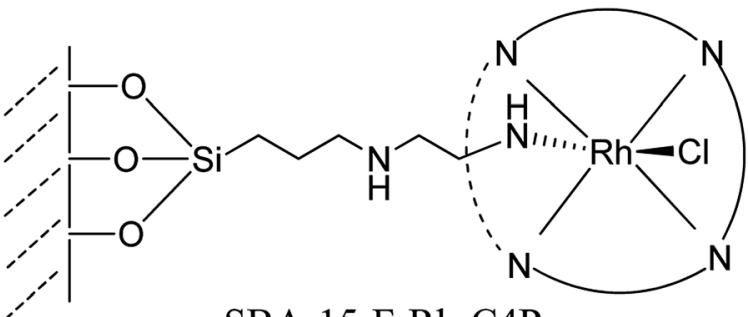

SBA-15-F-Rh-C4P

153

152<smiles>O=[N+]([O-])c1ccccc1</smiles>

154

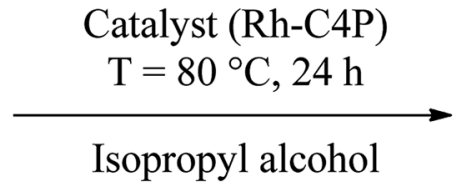

Isopropyl alcohol<smiles>Nc1ccccc1</smiles>

155

Scheme 16 Reduction of nitrobenzene to aniline using a diamino-functionalized SBA-15 surface-grafted Rh-C4P catalyst (153).

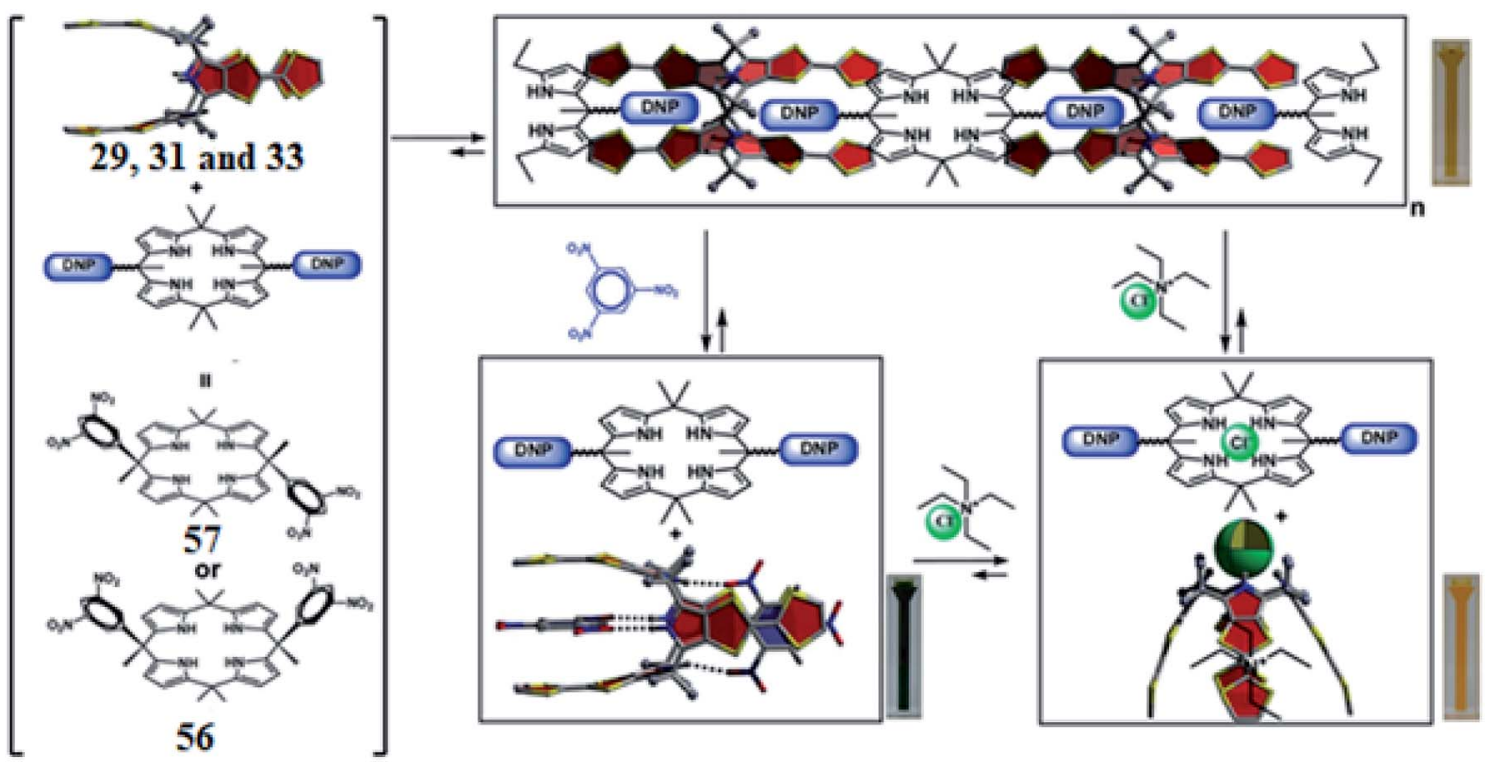

Fig. 40 Diagrammatic depiction of heterocomplementary self-association of TTF-C4Ps 29, 31, and 33 with 56 and 57 (reproduced with permission from ref. 56. Copyright 2018 American Chemical Society).

deficient in nature (Fig. 40). ${ }^{193}$ When these guests were combined with TTF-C4Ps $(\mathbf{2 9}, \mathbf{3 1}$, and 33$)$ in halogenated solvents, oligomeric materials were generated. The observed self-assembly reflects a stabilizing grouping of $\pi-\pi$ donoracceptor interactions and hydrogen bonding. Upon the addition of $\mathrm{Cl}^{-}$or trinitrobenzene (TNB), the self-assembled assemblies experience disaggregation to generate distinct host-guest supramolecular ensembles, as can be inferred from Fig. 40. Therefore, two different stimuli, such as $\mathrm{Cl}^{-}$and
TNB, can be employed to disrupt the supramolecular oligomers. ${ }^{56}$

In another experiment, Aydogan and coworkers synthesized a triazole-bridged bis-C4P $\mathbf{1 5 7}$ for the construction of thermoresponsive AABB-type linear supramolecular polymers (Fig. 41). This became possible in terms of the utilization of hydrogen bonding interactions among the NHs of C4P and the carboxylate components of tetrabutylammonium suberate 156. ${ }^{194}$ 


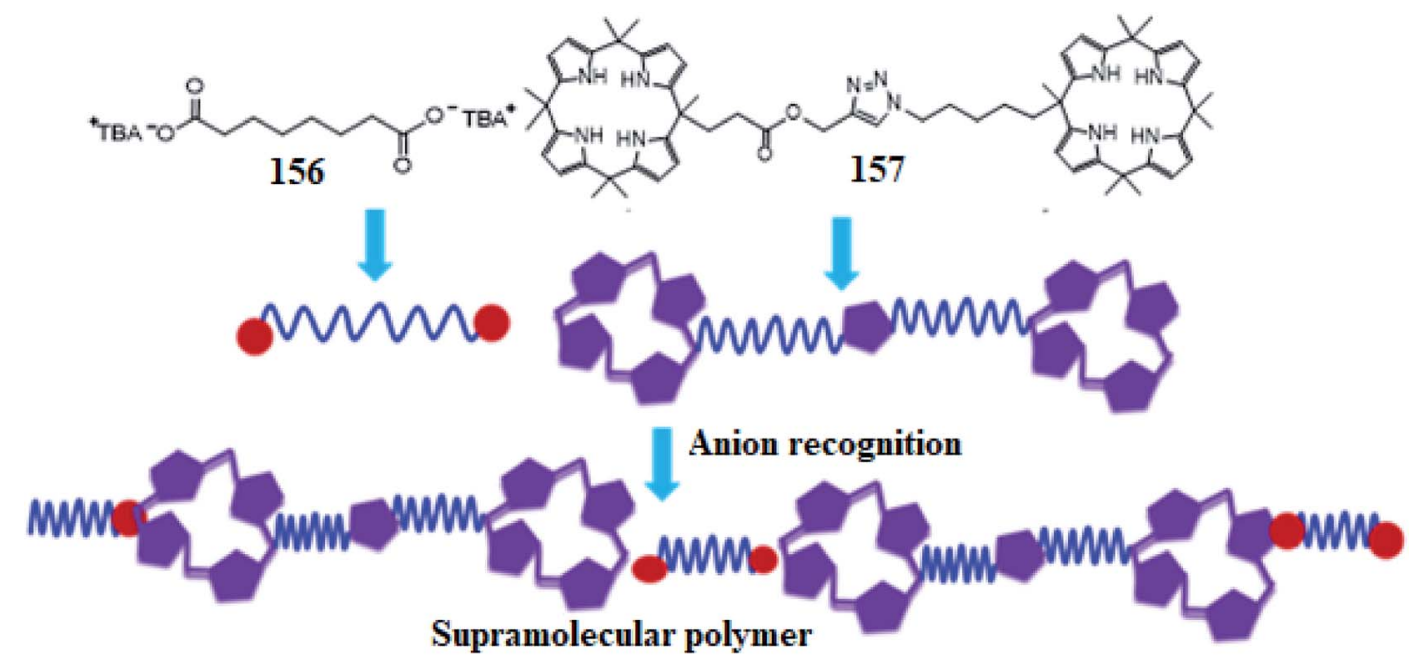

Fig. 41 Molecular structures and pictorial depictions of 156 and 157, and an illustration of AABB-type linear supramolecular polymers.

\section{Conclusions and outlook}

In summary, $\mathrm{C} 4 \mathrm{P}$ is a versatile and striking receptor system for many anions and ion pairs. In order to amend the intrinsic selectivity and acquire enhanced anion binding affinity of C4Ps, an array of novel and tailored calixpyrroles and their derivatives have been synthesized from simple and commercially available starting materials using simpler synthetic procedures. By means of its structural diversity, inimitable conformations, and useful molecular recognition properties, calixpyrrole is evolving as a new generation macrocyclic host molecule at the heart of supramolecular chemistry. Although several reviews of C4Ps have been reported in the literature, numerous important applications of C4Ps are missing in existing accounts. We believe that the current report definitely represents a new episode in the chemistry of C4Ps. As far as future perspectives regarding the applications of $\mathrm{C} 4 \mathrm{P}$ derivatives are concerned, we believe that this member of the supramolecular chemistry family will be further explored in the areas of drug delivery, catalysis, molecular machines and solubility in aqueous medium.

\section{Conflicts of interest}

The authors declare no conflicts of interest.

\section{Acknowledgements}

We are grateful to DST-SERB New Delhi for financial support (Project File no. ECR/2017/000821). I. A. R. thanks CSIR, New Delhi for the award of the junior research fellowship. R. A. thanks Jamia Millia Islamia, New Delhi for providing the necessary research facilities.

\section{References}

1 F. Biedermann and H.-J. Schneider, Chem. Rev., 2016, 116, 5216-5300.

2 A. S. Mahadevi and G. N. Sastry, Chem. Rev., 2016, 116, 2775-2825.

3 L. Kovbasyuk and R. Krämer, Chem. Rev., 2004, 104, 31613188.

4 A. Aydogan, G. Lee, C.-H. Lee and J. L. Sessler, Chem.-Eur. J., 2015, 21, 2368-2376.

5 P. A. Gale, J. L. Sessler, V. Král and V. Lynch, J. Am. Chem. Soc., 1996, 118, 5140-5141.

6 D. S. Kim and J. L. Sessler, Chem. Soc. Rev., 2015, 44, 532546.

7 C.-H. Lee, Bull. Korean Chem. Soc., 2011, 32, 768-778.

8 B. Mokhtari and K. Pourabdollah, J. Inclusion Phenom. Macrocyclic Chem., 2013, 77, 23-31.

9 I. Saha, J. T. Lee and C.-H. Lee, Eur. J. Org. Chem., 2015, 3859-3885.

10 P. Ballester, Isr. J. Chem., 2011, 51, 710-724.

11 P. A. Gale, J. L. Sessler, V. Král and V. Lynch, J. Am. Chem. Soc., 1996, 118, 5140-5141.

12 P. A. Gale, P. Anzenbacher Jr and J. L. Sessler, Coord. Chem. Rev., 2001, 222, 57-102.

13 G. I. Vargas-Zúñiga and J. L. Sessler, Coord. Chem. Rev., 2017, 345, 281-296.

14 P. Buranaprasertsuk, Y. Tangsakol and W. Chavasiri, Catal. Commun., 2007, 8, 310-314.

15 V. Král, P. A. Gale, P. Anzenbacher Jr, K. Jursíková, V. Lynch and J. L. Sessler, Chem. Commun., 1998, 9-10.

16 P. A. Gale, Acc. Chem. Res., 2011, 44, 216-226.

17 H. Miyaji, P. Anzenbacher Jr, J. L. Sessler, E. R. Bleasdale and P. A. Gale, Chem. Commun., 1999, 1723-1724.

18 P. Gale, L. Twyman, C. Handlin and J. Sessler, Chem. Commun., 1999, 1851-1852. 
19 P. A. Gale, M. B. Hursthouse, M. E. Light, J. L. Sessler, C. N. Warriner and R. S. Zimmerman, Tetrahedron Lett., 2001, 42, 6759-6762.

20 A. F. D. de Namor, N. Al Hakawati, W. A. Hamdan, R. Soualhi, S. Korfali and L. Valiente, J. Hazard. Mater., 2017, 326, 61-68.

21 I. Abbas, H. Shamseddine and H. H. Hammud, Complex Met., 2014, 1, 57-68.

22 R. Nishiyabu and P. Anzenbacher, J. Am. Chem. Soc., 2005, 127, 8270-8271.

23 K. D. Bhatt, H. D. Shah, K. M. Modi, M. B. Narechania and C. Patel, Supramol. Chem., 2019, 31, 268-282.

24 J. L. Sessler, A. Andrievsky, P. A. Gale and V. Lynch, Angew. Chem., Int. Ed. Engl., 1996, 35, 2782-2785.

25 W. E. Allen, P. A. Gale, C. T. Brown, V. M. Lynch and J. L. Sessler, J. Am. Chem. Soc., 1996, 118, 12471-12472.

26 B. Turner, M. Botoshansky and Y. Eichen, Angew. Chem., Int. Ed., 1998, 37, 2475-2478.

27 A. Baeyer, Ber. Dtsch. Chem. Ges., 1886, 19, 2184-2185.

28 I.-W. Park, J. Yoo, S. Adhikari, J. S. Park, J. L. Sessler and C.-H. Lee, Chem.-Eur. J., 2012, 18, 15073-15078.

29 R. Custelcean, L. H. Delmau, B. A. Moyer, J. L. Sessler, W.-S. Cho, D. Gross, G. W. Bates, S. J. Brooks, M. E. Light and P. A. Gale, Angew. Chem., 2005, 117, 2593-2598.

30 P. A. Gale, J. L. Sessler, W. E. Allen, N. A. Tvermoes and V. Lynch, Chem. Commun., 1997, 665-666.

31 P. A. Gale, P. Anzenbacher Jr and J. L. Sessler, Coord. Chem. Rev., 2001, 222, 57-102.

32 P. Anzenbacher Jr, R. Nishiyabu and M. A. Palacios, Coord. Chem. Rev., 2006, 250, 2929-2938.

33 L. Adriaenssens, C. Estarellas, A. Vargas Jentzsch, M. Martinez Belmonte, S. Matile and P. Ballester, J. Am. Chem. Soc., 2013, 135, 8324-8330.

34 K.-C. Chang, T. Minami, P. Koutnik, P. Y. Savechenkov, Y. Liu and P. Anzenbacher, J. Am. Chem. Soc., 2014, 136, 1520-1525.

35 S.-H. Kim, S.-J. Hong, J. Yoo, S. K. Kim, J. L. Sessler and C.-H. Lee, Org. Lett., 2009, 11, 3626-3629.

36 S. P. Mahanta, B. S. Kumar, S. Baskaran, C. Sivasankar and P. K. Panda, Org. Lett., 2012, 14, 548-551.

37 C. D. Kumar, K. Sirisha, D. K. Dhaked, P. Lokesh, A. V. S. Sarma, P. V. Bharatam, S. Kantevari and P. Sripadi, J. Org. Chem., 2015, 80, 1746-1753.

38 Z. Shen, Y. Zhang and F. Jin, RSC Adv., 2012, 2, 797-801.

39 A. Kuo, Chem, 2011, 1, 1-8.

40 V. V. Chelintzev and B. V. Tronov, J. Russ. Phys.-Chem. Soc., 1916, 48, 105-155.

41 P. Rothemund and C. L. Gage, J. Am. Chem. Soc., 1955, 77, 3340-3342.

42 W. H. Brown, B. J. Hutchinson and M. H. MacKinnon, Can. J. Chem., 1971, 49, 4017-4022.

43 H. Takakura, K. Nomura, H. Tanino and K. Okada, Tetrahedron Lett., 1999, 40, 2989-2992.

44 P. M. Petersen, C. J. Hawker, N. P. J. Stamford, F. J. Leeper and A. R. Battersby, J. Chem. Soc., Perkin Trans. 1, 1998, 1531-1540.
45 R. Nishiyabu, M. A. Palacios, W. Dehaen and P. Anzenbacher, J. Am. Chem. Soc., 2006, 128, 11496-11504. 46 Y.-D. Wu, D.-F. Wang and J. L. Sessler, J. Org. Chem., 2001, 66, 3739-3746.

47 S. M. Singh Chauhan and S. Mishra, Molecules, 2011, 16, 7256-7266.

48 S. K. Kim, D. E. Gross, D.-G. Cho, V. M. Lynch and J. L. Sessler, J. Org. Chem., 2011, 76, 1005-1012.

49 J. L. Sessler, W.-S. Cho, D. E. Gross, J. A. Shriver, V. M. Lynch and M. Marquez, J. Org. Chem., 2005, 70, 5982-5986.

50 E. K. Woller, V. V. Smirnov and S. G. DiMagno, J. Org. Chem., 1998, 63, 5706-5707.

51 A. Aydogan and A. Akar, Helv. Chim. Acta, 2014, 97, 14271432.

52 K. A. Nielsen, J. O. Jeppesen, E. Levillain and J. Becher, Angew. Chem., Int. Ed., 2003, 42, 187-191.

53 K. A. Nielsen, W.-S. Cho, J. O. Jeppesen, V. M. Lynch, J. Becher and J. L. Sessler, J. Am. Chem. Soc., 2004, 126, 16296-16297.

54 K. A. Nielsen, W.-S. Cho, J. Lyskawa, E. Levillain, V. M. Lynch, J. L. Sessler and J. O. Jeppesen, J. Am. Chem. Soc., 2006, 128, 2444-2451.

55 J. S. Park, C. Bejger, K. R. Larsen, K. A. Nielsen, A. Jana, V. M. Lynch, J. O. Jeppesen, D. Kim and J. L. Sessler, Chem. Sci., 2012, 3, 2685.

56 J. S. Park and J. L. Sessler, Acc. Chem. Res., 2018, 51, 24002410.

57 S. Bähring, H. D. Root, J. L. Sessler and J. O. Jeppesen, Org. Biomol. Chem., 2019, 17, 2594-2613.

58 G. Cafeo, G. Carbotti, A. Cuzzola, M. Fabbi, S. Ferrini, F. H. Kohnke, G. Papanikolaou, M. R. Plutino, C. Rosano and A. J. P. White, J. Am. Chem. Soc., 2013, 135, 2544-2551.

59 G. Cafeo, F. H. Kohnke, G. Mezzatesta, A. Profumo, C. Rosano, A. Villari and A. J. P. White, Chem.-Eur. J., 2015, 21, 5323-5327.

60 Q. He, M. Kelliher, S. Bähring, V. M. Lynch and J. L. Sessler, J. Am. Chem. Soc., 2017, 139, 7140-7143.

61 C. Caltagirone, J. R. Hiscock, M. B. Hursthouse, M. E. Light and P. A. Gale, Chem.-Eur. J., 2008, 14, 10236-10243.

62 A. Basu and G. Das, Dalton Trans., 2012, 41, 10792.

63 S. K. Dey and G. Das, Dalton Trans., 2012, 41, 8960.

64 W. Chen, C. Guo, Q. He, X. Chi, V. M. Lynch, Z. Zhang, J. Su, H. Tian and J. L. Sessler, J. Am. Chem. Soc., 2019, 141, 14798-14806.

65 L. Adriaenssens, G. Gil-Ramírez, A. Frontera, D. Quiñonero, E. C. Escudero-Adán and P. Ballester, J. Am. Chem. Soc., 2014, 136, 3208-3218.

66 J. Sabek, L. Adriaenssens, T. Guinovart, E. J. Parra, F. X. Rius, P. Ballester and P. Blondeau, Chem.-Eur. J., 2015, 21, 448-454.

67 Y.-C. He, Z.-X. Ren, X.-F. Zhao, Y.-B. Zhang, J.-H. Wang, J.-B. Chao and M.-L. Wang, Tetrahedron, 2019, 75, 130491.

68 R. Dutta, S. Samala, H. Jo, K. M. Ok and C.-H. Lee, J. Org. Chem., 2019, 84, 6851-6857.

69 E. Mulugeta, Q. He, D. Sareen, S.-J. Hong, J. H. Oh, V. M. Lynch, J. L. Sessler, S. K. Kim and C.-H. Lee, Chem, 2017, 3, 1008-1020. 
70 E. Mulugeta, R. Dutta, Q. He, V. Lynch, J. Sessler and C.-H. Lee, Eur. J. Org. Chem., 2017, 4891-4895.

71 A. Barattucci, P. Bonaccorsi, G. Cafeo, F. H. Kohnke and T. Papalia, Tetrahedron, 2011, 67, 7548-7556.

72 T. Wang and J. Liu, Adv. Theory Simul., 2018, 1, 1700010.

73 T. Wang, J. Liu, H. Sun, L. Chen, J. Dong, L. Sun and Y. Bi, RSC Adv., 2014, 4, 1864-1873.

74 V. Březina, S. Ishihara, J. Lang, L. Hanyková, K. Ariga, J. P. Hill and J. Labuta, ChemistryOpen, 2018, 7, 323-335.

75 J. Yoo, E. Jeoung and C.-H. Lee, Supramol. Chem., 2009, 21, 164-172.

76 S. Slovak, T. Evan-Salem and Y. Cohen, Org. Lett., 2010, 12, 4864-4867.

77 P. A. Gale, J. L. Sessler, V. Král and V. Lynch, J. Am. Chem. Soc., 1996, 118, 5140-5141.

78 P. Sokkalingam, D. S. Kim, H. Hwang, J. L. Sessler and C.-H. Lee, Chem. Sci., 2012, 3, 1819-1824.

79 D. Sareen, J. H. Lee, H. Hwang, S. Yoo and C.-H. Lee, Chem. Commun., 2016, 52, 5852-5855.

80 J. Lee, J. T. Brewster, B. Song, V. M. Lynch, I. Hwang, X. Li and J. L. Sessler, Chem. Commun., 2018, 54, 9422-9425.

81 S. Shao, A. Wang, M. Yang, S. Jiang and X. Yu, Synth. Commun., 2001, 31, 1421-1426.

82 R. Samanta, S. P. Mahanta, S. Chaudhuri, P. K. Panda and A. Narahari, Inorg. Chim. Acta, 2011, 372, 281-285.

83 C.-H. Lee, H.-K. Na, D.-W. Yoon, D.-H. Won, W.-S. Cho, V. M. Lynch, S. V. Shevchuk and J. L. Sessler, J. Am. Chem. Soc., 2003, 125, 7301-7306.

84 H. Miyaji, H.-K. Kim, E.-K. Sim, C.-K. Lee, W.-S. Cho, J. L. Sessler and C.-H. Lee, J. Am. Chem. Soc., 2005, 127, 12510-12512.

85 C.-H. Lee, H. Miyaji, D.-W. Yoon and J. L. Sessler, Chem. Commun., 2008, 24-34.

86 J. Yoo, M.-S. Kim, S.-J. Hong, J. L. Sessler and C.-H. Lee, J. Org. Chem., 2009, 74, 1065-1069.

87 P. K. Panda and C.-H. Lee, J. Org. Chem., 2005, 70, 31483156.

88 R. Samanta, S. P. Mahanta, S. Chaudhuri, P. K. Panda and A. Narahari, Inorg. Chim. Acta, 2011, 372, 281-285.

89 I.-W. Park, J. Yoo, B. Kim, S. Adhikari, S. K. Kim, Y. Yeon, C. J. E. Haynes, J. L. Sutton, C. C. Tong, V. M. Lynch, J. L. Sessler, P. A. Gale and C.-H. Lee, Chem.-Eur. J., 2012, 18, 2514-2523.

90 J. H. Yang, V. M. Lynch, J. L. Sessler and S. K. Kim, Supramol. Chem., 2019, 31, 203-210.

91 S. K. Kim, V. M. Lynch, B. P. Hay, J. S. Kim and J. L. Sessler, Chem. Sci., 2015, 6, 1404-1413.

92 C.-H. Lee, J.-S. Lee, H.-K. Na, D.-W. Yoon, H. Miyaji, W.-S. Cho and J. L. Sessler, J. Org. Chem., 2005, 70, 20672074.

93 C.-H. Lee, H.-K. Na, D.-W. Yoon, D.-H. Won, W.-S. Cho, V. M. Lynch, S. V. Shevchuk and J. L. Sessler, J. Am. Chem. Soc., 2003, 125, 7301-7306.

94 S.-D. Jeong, J. Yoo, H.-K. Na, D. Y. Chi and C.-H. Lee, Supramol. Chem., 2007, 19, 271-275.
95 H. Miyaji, S.-J. Hong, S.-D. Jeong, D.-W. Yoon, H.-K. Na, J. Hong, S. Ham, J. L. Sessler and C.-H. Lee, Angew. Chem., 2007, 119, 2560-2563.

96 P. K. Panda and C.-H. Lee, Org. Lett., 2004, 6, 671-674.

97 S.-H. Kim, S.-J. Hong, J. Yoo, S. K. Kim, J. L. Sessler and C.-H. Lee, Org. Lett., 2009, 11, 3626-3629.

98 S. K. Kim, J. L. Sessler, D. E. Gross, C.-H. Lee, J. S. Kim, V. M. Lynch, L. H. Delmau and B. P. Hay, J. Am. Chem. Soc., 2010, 132, 5827-5836.

99 N. Busschaert, C. Caltagirone, W. Van Rossom and P. A. Gale, Chem. Rev., 2015, 115, 8038-8155.

100 P. A. Gale, E. N. W. Howe and X. Wu, Chem, 2016, 1, 351422.

101 R. Martínez-Máñez and F. Sancenón, Chem. Rev., 2003, 103, 4419-4476.

102 M. G. Chudzinski, C. A. McClary and M. S. Taylor, J. Am. Chem. Soc., 2011, 133, 10559-10567.

103 A. Frontera, P. Gamez, M. Mascal, T. J. Mooibroek and J. Reedijk, Angew. Chem., Int. Ed., 2011, 50, 9564-9583.

104 P. Ballester, Acc. Chem. Res., 2013, 46, 874-884.

105 P. Gamez, T. J. Mooibroek, S. J. Teat and J. Reedijk, Acc. Chem. Res., 2007, 40, 435-444.

106 M. Giese, M. Albrecht and K. Rissanen, Chem. Rev., 2015, 115, 8867-8895.

107 M. Giese, M. Albrecht and K. Rissanen, Chem. Commun., 2016, 52, 1778-1795.

108 M. Giese, M. Albrecht and K. Rissanen, Chem. Rev., 2015, 115, 8867-8895.

109 M. Giese, M. Albrecht and K. Rissanen, Chem. Commun., 2016, 52, 1778-1795.

110 A. Andrievsky, F. Ahuis, J. L. Sessler, F. Vögtle, D. Gudat and M. Moini, J. Am. Chem. Soc., 1998, 120, 9712-9713.

111 S. Burley and G. Petsko, Science, 1985, 229, 23-28.

112 D. A. Dougherty, Science, 1996, 271, 163-168.

113 C. A. Hunter and J. K. M. Sanders, J. Am. Chem. Soc., 1990, 112, 5525-5534.

114 R. D. Shannon, Acta Crystallogr., Sect. A: Cryst. Phys., Diffr., Theor. Gen. Crystallogr., 1976, 32, 751-767.

115 M. Mascal, A. Armstrong and M. D. Bartberger, J. Am. Chem. Soc., 2002, 124, 6274-6276.

116 I. Alkorta, I. Rozas and J. Elguero, J. Am. Chem. Soc., 2002, 124, 8593-8598.

117 S. C. Zimmerman, C. M. VanZyl and G. S. Hamilton, J. Am. Chem. Soc., 1989, 111, 1373-1381.

118 A. Kim, R. Ali, S. H. Park, Y.-H. Kim and J. S. Park, Chem. Commun., 2016, 52, 11139-11142.

119 G. Gil-Ramírez, E. C. Escudero-Adán, J. Benet-Buchholz and P. Ballester, Angew. Chem., 2008, 120, 4182-4186.

120 S. K. Kim and J. L. Sessler, Acc. Chem. Res., 2014, 47, 25252536.

121 J. S. Park, J. Kim, Y.-H. Kim and J. L. Sessler, RSC Adv., 2015, 5, 69259-69262.

122 J. S. Park, T. T. Tran, J. Kim and J. L. Sessler, Chem. Commun., 2018, 54, 4553-4556.

123 J. S. Park, J. Park, Y. J. Yang, T. T. Tran, I. S. Kim and J. L. Sessler, J. Am. Chem. Soc., 2018, 140, 7598-7604. 
124 K. A. Nielsen, W.-S. Cho, J. Lyskawa, E. Levillain, V. M. Lynch, J. L. Sessler and J. O. Jeppesen, J. Am. Chem. Soc., 2006, 128, 2444-2451.

125 A. Jana, M. Ishida, J. S. Park, S. Bähring, J. O. Jeppesen and J. L. Sessler, Chem. Rev., 2017, 117, 2641-2710.

126 N. L. Bill, O. Trukhina, J. L. Sessler and T. Torres, Chem. Commun., 2015, 51, 7781-7794.

127 L. Escobar and P. Ballester, Org. Chem. Front., 2019, 6, 1738-1748.

128 J. S. Park, F. Le Derf, C. M. Bejger, V. M. Lynch, J. L. Sessler, K. A. Nielsen, C. Johnsen and J. O. Jeppesen, Chem.-Eur. J., 2010, 16, 848-854.

129 T. Hirao, D. S. Kim, X. Chi, V. M. Lynch, K. Ohara, J. S. Park, K. Yamaguchi and J. L. Sessler, Nat. Commun., 2018, 9, 823.

130 W. Zhu, J. S. Park, J. L. Sessler and A. Gaitas, Appl. Phys. Lett., 2011, 98, 123501.

131 S. K. Dwivedi, S. S. Razi and A. Misra, New J. Chem., 2019, 43, 5126-5132.

132 S.-J. Hong, J. Yoo, S.-H. Kim, J. S. Kim, J. Yoon and C.-H. Lee, Chem. Commun., 2009, 189-191.

133 A. Aydogan, A. Koca, M. K. Şener and J. L. Sessler, Org. Lett., 2014, 16, 3764-3767.

134 E. Baysak, S. Yuvayapan, A. Aydogan and G. Hizal, Sens. Actuators, B, 2018, 258, 484-491.

135 P. A. Gale, P. A. Gale, L. J. Twyman, C. I. Handlin and J. L. Sessler, Chem. Commun., 1999, 1851-1852.

136 T. Wang, J. Liu, D. Zhang and H. Sun, RSC Adv., 2014, 4, 44948-44958.

137 Y. S. Rosokha, S. V. Lindeman, S. V. Rosokha and J. K. Kochi, Angew. Chem., Int. Ed., 2004, 43, 4650-4652.

138 P. D. Beer and P. A. Gale, Angew. Chem., Int. Ed., 2001, 40, 486-516.

139 B. D. Smith, in Macrocyclic Chemistry, Springer, 2005, pp. 137-151.

140 J. Huskens, L. Prins, R. Haag and B. Ravoo, Multivalency: Concepts, Research and Applications, 2018.

141 A. J. McConnell and P. D. Beer, Angew. Chem., Int. Ed., 2012, 51, 5052-5061.

142 S. K. Kim, G. I. Vargas-Zúñiga, B. P. Hay, N. J. Young, L. H. Delmau, C. Masselin, C.-H. Lee, J. S. Kim, V. M. Lynch, B. A. Moyer and J. L. Sessler, J. Am. Chem. Soc., 2012, 134, 1782-1792.

143 I.-W. Park, J. Yoo, S. Adhikari, J. S. Park, J. L. Sessler and C.-H. Lee, Chem.-Eur. J., 2012, 18, 15073-15078.

144 Q. He, G. I. Vargas-Zúñiga, S. H. Kim, S. K. Kim and J. L. Sessler, Chem. Rev., 2019, 119, 9753-9835.

145 S. K. Kim and J. L. Sessler, Chem. Soc. Rev., 2010, 39, 37843809.

146 S. K. Kim, V. M. Lynch, N. J. Young, B. P. Hay, C.-H. Lee, J. S. Kim, B. A. Moyer and J. L. Sessler, J. Am. Chem. Soc., 2012, 134, 20837-20843.

147 S. K. Kim, B. P. Hay, J. S. Kim, B. A. Moyer and J. L. Sessler, Chem. Commun., 2013, 49, 2112-2114.

148 X. Ji, X. Chi, M. Ahmed, L. Long and J. L. Sessler, Acc. Chem. Res., 2019, 52, 1915-1927.

149 J. R. Romero, G. Aragay and P. Ballester, Chem. Sci., 2017, 8, 491-498.
150 M. Xue, Y. Yang, X. Chi, X. Yan and F. Huang, Chem. Rev., 2015, 115, 7398-7501.

151 R. Molina-Muriel, G. Aragay, E. C. Escudero-Adán and P. Ballester, J. Org. Chem., 2018, 83, 13507-13514.

152 Y. Yeon, S. Leem, C. Wagen, V. M. Lynch, S. K. Kim and J. L. Sessler, Org. Lett., 2016, 18, 4396-4399.

153 J. S. Park, E. Karnas, K. Ohkubo, P. Chen, K. M. Kadish, S. Fukuzumi, C. W. Bielawski, T. W. Hudnall, V. M. Lynch and J. L. Sessler, Science, 2010, 329, 1324-1327.

154 S. Fukuzumi, K. Ohkubo, Y. Kawashima, D. S. Kim, J. S. Park, A. Jana, V. M. Lynch, D. Kim and J. L. Sessler, J. Am. Chem. Soc., 2011, 133, 15938-15941.

155 C. C. Tong, R. Quesada, J. L. Sessler and P. A. Gale, Chem. Commun., 2008, 6321-6323.

156 I. R. Hamilton, J. Dent. Res., 1990, 69, 660-667.

157 R. M. F. Batista, E. Oliveira, S. P. G. Costa, C. Lodeiro and M. M. M. Raposo, Supramol. Chem., 2014, 26, 71-80.

158 S. Camiolo, P. A. Gale, M. B. Hursthouse, M. E. Light and A. J. Shi, Chem. Commun., 2002, 758-759.

159 P. A. Gale, K. Navakhun, S. Camiolo, M. E. Light and M. B. Hursthouse, J. Am. Chem. Soc., 2002, 124, 1122811229.

160 T. Gunnlaugsson, P. E. Kruger, P. Jensen, F. M. Pfeffer and G. M. Hussey, Tetrahedron Lett., 2003, 44, 8909-8913.

161 D. Esteban-Gómez, L. Fabbrizzi and M. Licchelli, J. Org. Chem., 2005, 70, 5717-5720.

162 K. Pandurangan, J. A. Kitchen and T. Gunnlaugsson, Tetrahedron Lett., 2013, 54, 2770-2775.

163 M. Yano, C. C. Tong, M. E. Light, F. P. Schmidtchen and P. A. Gale, Org. Biomol. Chem., 2010, 8, 4356-4363.

164 X. Wu, L. W. Judd, E. N. W. Howe, A. M. Withecombe, V. Soto-Cerrato, H. Li, N. Busschaert, H. Valkenier, R. Pérez-Tomás, D. N. Sheppard, Y.-B. Jiang, A. P. Davis and P. A. Gale, Chem, 2016, 1, 127-146.

165 H. J. Clarke, E. N. W. Howe, X. Wu, F. Sommer, M. Yano, M. E. Light, S. Kubik and P. A. Gale, J. Am. Chem. Soc., 2016, 138, 16515-16522.

166 S. Venkataraman, J. L. Hedrick, Z. Y. Ong, C. Yang, P. L. R. Ee, P. T. Hammond and Y. Y. Yang, Adv. Drug Delivery Rev., 2011, 63, 1228-1246.

167 K. Yang, L. Weng, Y. Cheng, H. Zhang, J. Zhang, Q. Wu and T. Xu, J. Phys. Chem. B, 2011, 115, 2185-2195.

168 S. H. Medina and M. E. H. El-Sayed, Chem. Rev., 2009, 109, 3141-3157.

169 R. K. Tekade, P. V. Kumar and N. K. Jain, Chem. Rev., 2009, 109, 49-87.

170 R. Lappano, C. Rosano, A. Pisano, M. F. Santolla, E. M. De Francesco, P. De Marco, V. Dolce, M. Ponassi, L. Felli, G. Cafeo, F. H. Kohnke, S. Abonante and M. Maggiolini, Dis. Models Mech., 2015, 8, 1237-1246.

171 R. Siegel, D. Naishadham and A. Jemal, Ca-Cancer J. Clin., 2012, 62, 10-29.

172 E. Giannoni, F. Bianchini, L. Masieri, S. Serni, E. Torre, L. Calorini and P. Chiarugi, Cancer Res., 2010, 70, 69456956.

173 A. Madeo and M. Maggiolini, Cancer Res., 2010, 70, 60366046. 
174 Z. Zhou, J. X. Qiao, A. Shetty, G. Wu, Y. Huang, N. E. Davidson and Y. Wan, Cell. Mol. Life Sci., 2014, 71, 1549.

175 S.-K. Ko, S. K. Kim, A. Share, V. M. Lynch, J. Park, W. Namkung, W. Van Rossom, N. Busschaert, P. A. Gale, J. L. Sessler and I. Shin, Nat. Chem., 2014, 6, 885-892.

176 S.-H. Park, S.-H. Park, E. N. W. Howe, J. Y. Hyun, L.-J. Chen, I. Hwang, G. Vargas-Zuñiga, N. Busschaert, P. A. Gale, J. L. Sessler and I. Shin, Chem, 2019, 5, 2079-2098.

177 M. Geretto, M. Ponassi, M. Casale, A. Pulliero, G. Cafeo, F. Malagreca, A. Profumo, E. Balza, R. Bersimbaev, F. H. Kohnke, C. Rosano and A. Izzotti, Sci. Rep., 2018, 8, 11075.

178 P. Heikinheimo, V. Tuominen, A.-K. Ahonen, A. Teplyakov, B. S. Cooperman, A. A. Baykov, R. Lahti and A. Goldman, Proc. Natl. Acad. Sci. U. S. A., 2001, 98, 3121-3126.

179 C. E. Powell, M. P. Cifuentes, M. G. Humphrey, A. C. Willis, J. P. Morrall and M. Samoc, Polyhedron, 2007, 26, 284-289.

180 H. Martínez-García, D. Morales, J. Pérez, D. J. Coady, C. W. Bielawski, D. E. Gross, L. Cuesta, M. Marquez and J. L. Sessler, Organometallics, 2007, 26, 6511-6514.

181 J. J. Perry IV, J. A. Perman and M. J. Zaworotko, Chem. Soc. Rev., 2009, 38, 1400-1417.

182 C. Maeda, Y. Miyazaki and T. Ema, Catal. Sci. Technol., 2014, 4, 1482.

183 Q.-W. Song, Z.-H. Zhou and L.-N. He, Green Chem., 2017, 19, $3707-3728$.
184 C. Maeda, S. Sasaki, K. Takaishi and T. Ema, Catal. Sci. Technol., 2018, 8, 4193-4198.

185 K. Anjali, M. Ahmed, J. Christopher and A. Sakthivel, Dalton Trans., 2018, 47, 12353-12361.

186 J. Won, K. M. Lee, Y. S. Kang, S.-K. Chang, C. K. Kim and C. K. Kim, Macromol. Res., 2006, 14, 404-407.

187 V. K. Jain, H. C. Mandalia, H. S. Gupte and D. J. Vyas, Talanta, 2009, 79, 1331-1340.

188 A. Kałędkowski and A. W. Trochimczuk, React. Funct. Polym., 2006, 66, 740-746.

189 A. Kałędkowski and A. W. Trochimczuk, React. Funct. Polym., 2006, 66, 957-966.

190 A. Danil de Namor and I. Abbas, Anal. Methods, 2010, 2, 6371.

191 A. Aydogan, D. J. Coady, V. M. Lynch, A. Akar, M. Marquez, C. W. Bielawski and J. L. Sessler, Chem. Commun., 2008, 1455-1457.

192 A. Aydogan, D. J. Coady, S. K. Kim, A. Akar, C. W. Bielawski, M. Marquez and J. L. Sessler, Angew. Chem., Int. Ed., 2008, 47, 9648-9652.

193 J. S. Park, K. Y. Yoon, D. S. Kim, V. M. Lynch, C. W. Bielawski, K. P. Johnston and J. L. Sessler, Proc. Natl. Acad. Sci. U. S. A., 2011, 108, 20913-20917.

194 S. Yuvayapan and A. Aydogan, Chem. Commun., 2019, 55, 8800-8803. 